\title{
The Effect of Internal and External Factors on the Stock Price of Pharmaceutical Companies in Emerging and Emerged Markets
}

\author{
MANEESH KUMAR PANDEY \\ National Research University Higher School of Economics, St. Petersburg School of Economics and \\ Management, Kantemirovskaya Ulitsa, 3А корпус 1, St Petersburg, Russia, 194100
}

\begin{abstract}
:
Purpose: The global financial crisis of 2008, considered by many economists to have been the most consequential since the great depression of the 1930s, altered the very fabric of global macro-economy and left many short and long-term impressions at various levels. Though the catastrophic effect of that meltdown penetrated the global market with lightning speed, the aftermath was rather uneven in its manifestation. Countries of American and European continent suffered severely but Asian countries were rather mildly affected and the reason behind this uneven perfusion could be the disparity in the economic environment at the microeconomic and macroeconomic levels in different continents.
\end{abstract}

The Purpose of carrying out this research is to unveil the influence of internal microeconomic factors at firm level as well as external macroeconomic factors at country level on the overall stock price of Pharmaceutical companies of Asia's emerging market (India) and emerged markets of United States of America and Western European countries (Germany, France, UK, and Switzerland) after the global financial crisis of year 2008.

Research Design/Methodology: During the present course of the investigation, secondary data of forty pharmaceutical companies from the year 2008 to the year 2017 has been employed to perform an empirical analysis. Moreover, an explanatory and comparative research design has been applied to corroborate the statistical outcome.

For statistical analysis, EViews 10 student version, statistical software has been used on the dependent variable "Organization Stock Price" and several internal independent variables such as Return on Equity (ROE), Earnings Per Share (EPS), Dividend Per Share (DPS), Dividend Payout Ratio (DPR), PE ratio, firm's asset as well as few macroeconomic level independent variables such as corporate tax, inflation rate, GDP and exchange rate.

Findings: Price movement of stocks is not independent in nature and doesn't follow a random walk. There are several factors responsible for the stock price movement such as investor sentiment, social, economic, environment and organization's operational and financial situation etc. This study shows how the aforementioned factors affect the stock prices of sample companies of emerging and emerged markets.

Practical Implications: The outcome of this research could be helpful to managers to regulate organization's financial ratios and address the macroeconomic fluctuations to sustain the momentum of the stock price that will inadvertently increase the value of the company. From the investor's point of view, this study could provide them with better anticipation of future trends in the stock prices.

Originality/Value: This study offers a contemporary review of the role of organizational and macroeconomic factors on the share price of companies and the stock market, thus contributes to the available literature in this domain.

Keywords: Pharmaceutical Companies, Emerging Market, Emerged Market, Microeconomic Variables, Macroeconomic Variables

DOI: $10.7176 / \mathrm{EJBM} / 11-36-18$

Publication date: December $31^{\text {st }} 2019$ 


\section{Introduction}

The year 2008 brought about successive quarters of negative growth in the gross domestic product (GDP) of countries across the continents and had a damaging effect on the industries because economic downturns directly triggered a strong decline in the performance of various macroeconomic Key Performance Indicators (KPIs). Against that grim backdrop, global pharmaceutical industry fared better as they were not dangerously reliant on borrowing and therefore less exposed to the macro environment (Law, 2008). Although the pharmaceutical industry has always had its own share of problems, crash of 2008 had got two things going for them: they became more attractive for investors and unsettled times raised the demand for medicines. On the other hand, lack of global spending from governments and disparity in public medicines coverage inadvertently pushed the Pharmaceutical industry to uncharted territories.

To thrive and excel in the testing times, pharmaceutical companies have come under great pressure to increase the efficiency and effectiveness of their operations. A looming patent cliff, with approximately $40 \%$ of the top-selling products worldwide going out of patent, has been resulting in companies losing their patents with the substantial impact of the revenue. There is also a consolidation of providers (doctors, group practices, hospitals, health systems) into larger accounts that have greater influence and economies of scale. Healthcare reform, driven by government policy, is reshaping the delivery of healthcare, from care coordination to reimbursement strategies, impacting behaviours and tactics within the marketplace (O'riordan et. al., 2016). Tightening regulations and ballooning healthcare cost have also impacted the healthcare operating models, reflecting the major shift in marketing tactics and customer engagement to reporting requirements by the government, payers, and providers.

Amidst the mounting pressure coming from the aforementioned fronts, the fundamentals of the pharmaceutical industry have remained strong. The output of new drugs has been increasing and looks set to remain elevated over the next five years, largely based on the exciting new science of speciality medicines, to offset current and future patent expiries. After four years of falling or stagnating revenue from the year 2011 to year 2014, the industry returned to growth in year 2015 with acceleration and improved operating margins in the year 2016. But, the new science of speciality medicines faces a persistent affordability gap between payers and governments budgets and the sales forecasts for new products. Some notable, recent new launches have been struggling to perform on account of concerns over the prevailing price sensitive climate. The key impact of accelerating revenue growth and improving operating margins, despite falling profit margins, on investors has been profound. The shift to speciality drugs, backed by strong pipeline, has opened up avenues to investors worldwide to favour stocks backed by value driven companies with focus on personalized patient outcomes by leveraging technology collaboration and driving operational efficiency. Aftermath of the year 2008 meltdown was momentum-driven move to the downside soaked in pessimism and massive liquidity crunch.

The stock price is the primary indicator for investors to gauge the financial health of institutions. Listed institutions deploy their shares in the market to collect more funds to expand the business, unlike unlisted companies, who follow the Initial Public Offering (IPO) process. Moreover, stock price directly correlates with the amount of assets that the institution owns after the shareholder invests in the business, so this value is incurred on the balance sheet by the asset (Uddin, 2009). At firm-specific level, a bullish trend in the stock price of the firm reflects the confidence of investors in the fundamentals and performance of the firm and a bearish trend in the stock price of the firm reflects low confidence of investors in the fundamentals and performance of the firm. At the macroeconomic level, consumer prices, industrial production, exchange rate and the market rate of interest reflect bidirectional causation with stock prices affecting companies in both the short and long term.

From the standpoint of financial experts and economist, there are many firm level and macroeconomic factors, play a pivotal role in the firm's financial and business operations differently and eventually drive the stock price. It is important to take into consideration that macroeconomic factors are more decisive in their impact on the oscillation of many firm-level factors controlling the stock rally. Therefore, the overall impact of the aforementioned factors varies, depending on the nature of business and industry in which firms operate. Basically, there are two types of industries, based on their sensitivity towards fluctuation in the economic cycle:

- Cyclical Industries: Cyclical Industries and their stocks adhere tightly to the economic cycle. During the ascending economic phase, their stocks perform above average. However, during the descending economic phase, they get dipped into a downward direction. Example of cyclical industries such as automobile, Information technology, steel, tourism, fashion and so on. 
- Non-Cyclical Industries: Since non-cyclical industries manufacture and distribute goods and services, which are always required for society such as food, power, medicine, and other utilities, their stocks do not tightly attached with the economic cycle. As a result, they tend to perform rather neutrally during both the ascending and descending phases of the economic cycle.

Since medicines are one of the most basic needs for human being and animals to treat diseases and maintain a healthy life and pharmaceutical sector manufactures medicines to cater to this need of the global population, this industry is considered as a non-cyclical industry by economists and financial experts.

The main objectives of this study to investigate the collective and individual effects of internal microeconomic factors and external macroeconomic factors on the market stock price of Pharmaceutical companies in emerging and emerged markets. In case of India: most of the Indian companies had positive net income throughout the sample period that in turn made all financial ratios such as EPS, DPS, DPR, and PE ratio stay in positive territory. Since most of the companies were having consistent profit, the distributed dividends to stockholders followed a regular pattern whereas in the emerged market, apart from few big companies, most of the companies registered negative net income that affected their EPS which turned out into no dividend to shareholders. Though the pharmaceutical sector was generally considered as a non-cyclical industry, the fluctuation in GDP, inflation, interest rate, corporate tax, and exchange rate didn't affect the stock price of Indian pharmaceutical sector any significantly. But, in the case of the emerged market, fluctuation in corporate tax and exchange rate were the main drivers affecting the pharmaceutical industry.

\section{Literature Review}

Literature review section begins by shedding light on key trends and advancements the pharmaceutical industry has seen in the last 40 years, with emphasis on its outlook post-2008 global financial crisis. Subsequently, it focuses on explicatory research works related to the significance of firm-level factors and macroeconomic factors on the price of stocks by analyzing the current and previous studies done by the various researches and academicians. This section also gives a chance to understand whether managers and financial experts can predict the momentum of stocks more precisely by employing the outcome of these studies. Furthermore, by going through the multiple research works and studies, this section also tries to get insight into possible relationship between macroeconomic factors and firm-specific factors and impact of their mutual influence.

\section{Pharmaceutical Industry Overview:}

In the last 40 years, the pharmaceutical industry has seen myriads of scientific, technological and legal advancements; however, the industry has also been marred by various controversies in areas of clinical trials management, approval mechanism, increased pricing and pharmacovigilance.

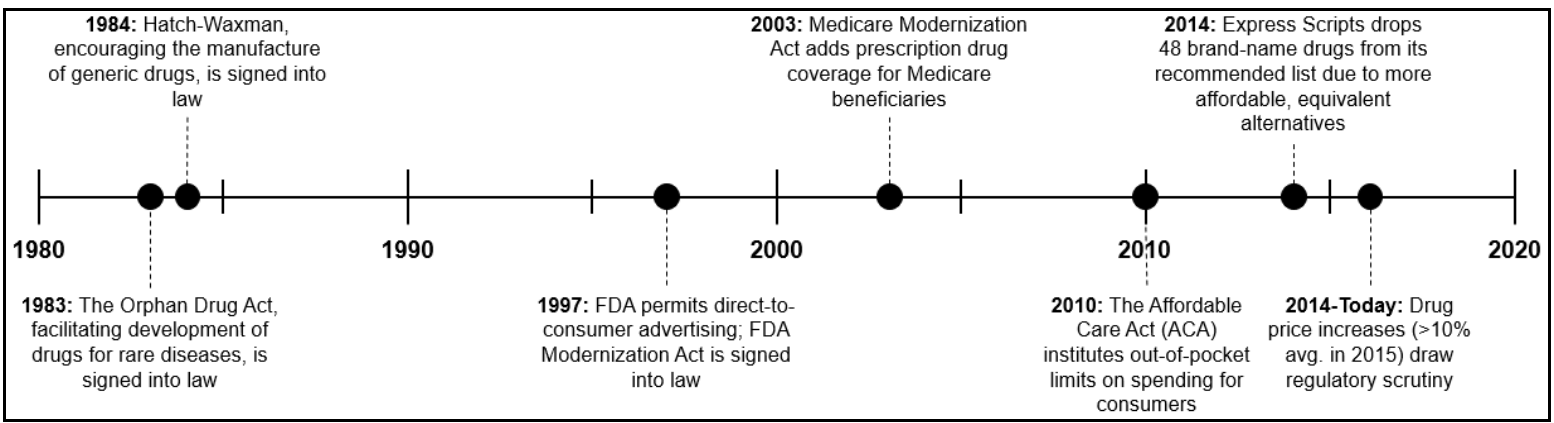

Figure 1: Key Milestones in the pharmaceutical industry (Accenture Research, 2016)

The key factors driving the Pharmaceutical industry are high R\&D cost, the discrepancy between list and real price, rising ageing population and high affordability of drugs. As a result, the pharmaceutical industry is increasingly moving towards sustainability through more segmentation, robust regulatory framework and continuous breakthroughs in New Drug Discovery process. 
In the wake of the Global economic crisis of 2008, where most of the Industry sectors had been hard hit, the pharmaceutical industry remained relatively unscathed. Key underlying factors behind that resilience were less sensitivity of economic trends and no price elasticity in time of crisis.

Despite the relatively modest outlook, biotech and smaller pharmaceutical niche players are feeling the pressure because of depleting funding sources on account of the credit crunch. On the other end of the spectrum, larger players are also feeling the heat because of intensified scrutiny on healthcare budget by both public and private players and that has let to further cost containment measures to reduce drug prices, increase generic substitutions and demand for new drug formulation. In contrast with many other industries, pharmaceutical companies especially the larger once generally have a strong balance sheet with little debt and therefore have maintained stronger leverage in this time of crisis and uncertainty.

\subsection{Theoretical Basis and Development of Hypothesis}

Since financial ratios are the computational result of several inter-connected firm-level factors, it is one of the most prevalent ways to make an estimation of the financial and operational efficiency of a firm. The financial ratio can be used to determine irregularities in the implementation of the company's operational activities by comparing the financial ratio with that of previous years (Wild et al., 2008). Hence, financial ratios are being used as a major pointer in order to examine the current position of firm's profitability, liquidity, income, utilization of assets, liability, etc., by performing intra-comparative analysis between current report and previous report of the same firm or inter-comparative analysis among many firms.

Return on Equity (ROE): Return on equity ratio (ROE) is considered a key measure of a company's earnings performance. The ROE provides information to common shareholders on how efficiently their money is being used. By analyzing ROE, shareholders can understand whether a firm is profit-enhancing or profitdepleting and whether management has the profit-earnings ability or not (Kijewska 2016). A rising ROE can signal that a company is able to grow profits without adding new equity into the Business, which dilutes the ownership share of existing shareholders (Thorp 2012).

$$
\text { Return on Equity }(R O E)=\frac{\text { Net Income }(N I)}{\text { Shareholder Equity }(E)}
$$

The higher Return on Equity (ROE) implies the higher profitability of firm that shows firm's management is utilizing investors' money in an efficient manner and investors can expect a higher rate of return on their investments which enhances the overall value of the firm and eventually increases the stock price. This ratio is also used to measure the ability of a company to use its own capital to generate profits for all shareholders, through both common and preferred stock. An increase in the company's stock price will provide a high return for investors. This will further increase the attractiveness of the company for investors. Karnawi Kamar (2017), conducted research to see the effect of Return on Equity and Debt to Equity ratio on the share price of listed cement companies at the Indonesian stock exchange. Statistical analysis revealed that together both factors produce a significant impact on the share price of companies. Moreover, ROE alone demonstrated a significant positive relationship with the share price of companies which proves that efficient utilization of inventors' money increases the price of shares. On the other hand, Haque and Faruquee (2013), studied the impact of fundamental factors on the share price of listed pharmaceutical companies of Dhaka stock exchange and found that ROE doesn't have any effect on the share price of companies. Fouzan Al Qaisi et. A1. (2016), showed in their study that ROE didn't have any effect on the stock price. However, Ursula Tamuntuan (2015), found a collective significance of ROE, ROA, and EPS on the stock price of food and beverages companies at Indonesian stock market but, ROE alone didn't produce any significant effect on stock prices.

Another study conducted by Fitri Sukmawati and Innes Garsela (2016), observed an inverse relationship between ROE and Share Price which means an increment in return on equity causes a decrement in the share price. Joanna L Saragih (2017), also found that ROE together with ROA and Debt-to-Equity ratio has no significant effect on the share price. However, ROE shows the insignificant positive partial effect on the share price.

Earnings per Share (EPS): Earning per share (EPS) is generally one of the most important financial ratios, uses to evaluate the stock price and the value of the firm. Earnings per share measures the amount of net income earned against each share. In other words, this is the amount of money each share of stock would receive if all of the profits were distributed to the outstanding shares at the end of the year. 
EPS are also a calculation that shows how profitable a company is from a shareholder's perspective. Therefore, a larger company's profits per share can be compared to the smaller company's profits per share.

EPS or basic earnings per share are calculated by subtracting preferred dividends from net income and dividing by the weighted average common shares outstanding.

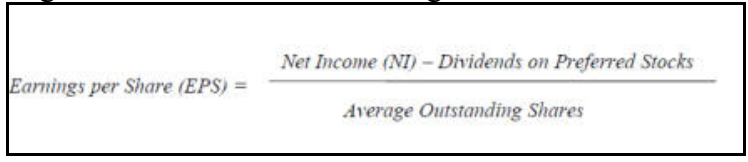

EPS are generally considered to be the single most important variable in determining a share's price. It is also a major component used to calculate the price-to-earnings valuation ratio (Besley 2006).

EPS is a carefully scrutinized metric that is often used as a barometer to gauge a company's profitability per unit of shareholder ownership. As such, earnings per share are a key driver of share prices. It is also used as the denominator in the frequently cited P/E ratio (Md. Rashidul et. al., 2014).

Pankaj Kumar (2017), studied the influence of EPS on the listed Indian automobile companies. The regression result showed a significant effect of EPS on the share price of automobile companies. Budhi Suparnihgsih (2017) and Ursula Tamuntuan (2015) found that EPS and other chosen variables simultaneously showed a significant effect on the share price of textile and garment companies of Indonesia stock exchange. Moreover, a partial significant positive effect of EPS was observed on the stock prices. Subramaniam V. A. and Tharshiga Murugesu (2013), studied the effect of the EPS on the share price of listed manufacturing companies in Sri Lanka. By employing regression techniques on the sample data, they found a strong significant positive relationship between EPS and Share Prices.

Md. Bellal Hossain and A. H. M. Asaduzzaman (2017) and Sayed Akif and Umara Nareen (2016), also supported the significant positive effect on the stock prices of sample companies. Sanjeet Sharma (2011), found in his study that EPS showed a significantly positive impact on the share price of sample companies.

Dividend per Share (DPS): Dividends are commonly defined as the distribution of earnings (past or present) in real assets among the shareholders of the firm in proportion to their ownership (Kapoor 2009). In other words, Dividend per share is the amount of perquisite issued by a firm for every common share outstanding. Dividends per share can be calculated by dividing the total number of dividends paid out by a firm, including interim dividends, over a period of time, by the number of shares outstanding (investopedia.com).

$$
\text { Dividend per Share }(D P S)=\frac{\text { Total dividends }- \text { Special dividends (if any) }}{\text { Ammual weighted Average of Outstanding Shares }}
$$

In a favourable economic environment, raising the dividend amount and frequency gives a very prominent signal about the strong performance and higher profitability of the firm to its shareholders. However, at times in order to maintain the confidence of shareholders in the firm, many big firms pay dividends on a regular basis to their shareholders even after getting an average or weak financial result.

Onyango Benedict Enrile (2018), conducted a research to understand the relationship between dividend per share (DPS) and the stock prices of listed companies at the Nairobi Stock Exchange, where author observed that DPS had a positive and significant effect on the share price of companies. Similarly, Sanjeet Sharma (2011), also observed a significant positive impact of DPS on share Prices.

On the other hand, Sayed Akif and Umara Nareen (2016), studied fifty non-financial companies of Karachi stock exchange to check the role of dividend policy on stock prices volatility and they found a significant negative effect of DPS on stock prices of companies. Similarly, Sebastianus Laurens, (2018) and Hashemijoo, M., Ardekani, A. M., \&Younesi, N. (2012) also found an inverse relationship between DPS and share price of companies. This inverse relationship between DPS and share price supports the dividend irrelevance theory.

Dividend Payout Ratio (DPR): According to Akinsulire (2014), the dividend payout ratio is the ratio of ordinary dividends to retained earnings. It signifies that what portion of the net profits distributed to shareholders as dividends and what portion kept for internal reinvestment. A high payout ratio simply shows a liberal distribution of profits whereas a low payout ratio reflects a conservative distribution policy. However, from the share valuation model, Simon (2009) asserts that the value of a share depends very much on the amount of dividend distributed to shareholders such that the higher the dividend payout ratio, the more attractive the share is to the shareholders.

Conversely, Hasan M, et, al (2015) found in their study that there is a negative impact of dividend payout ratio on the profitability of a firm in Pakistan's energy and textile sector. Similarly, Md. Bellal Hossain and A. H. M. Asaduzzaman (2017) did a study on the relationship between dividend policy and the stock price of 
the listed fuel, power, and cement industry of Bangladesh. They applied the random effect panel data regression model and observed a negative influence of DPR on stock prices.

Onyango Benedict Enrile (2018), conducted a research to understand the relationship between dividend per share (DPR) and the stock prices listed companies at the Nairobi Stock Exchange, where author observed that DPR didn't have any significant effect on the share price of companies whereas another research conducted by Hunjra et. al.(2014), to understand role of dividend policy, EPS, ROE, and profit after tax on the stock price. The regression result reflected a significant positive correlation between DPR and share price that shows distributing more dividends and keeping less retained earnings is a positive signal for increment in share price and this result also refutes dividend irrelevance theory.

$$
\text { Dividend Payout Ratio }=\frac{\text { Dividends Paid }}{\text { Net Income }} \text { or } \quad \frac{\text { Dividend per Share (DPS) }}{\text { Earnings per Share (EPS) }}
$$

In practice, decisions as to whether to pay out dividends or not, how much of the profits to pay a dividend and in what form the dividend should be paid are influenced by many internal and external factors. According to (Alfred, D. D. 2007) there are many internal and external factors such as company's operational sector, nature of the company, liquidity constraints, tax constraints, reinvestment opportunity, risk factors, and so on can influence the dividend payout strategies of a company.

Price-to-Earnings Ratio (P/E Ratio): The price-earnings ratio ( $\mathrm{P} / \mathrm{E}$ Ratio) is the ratio for assigning a value for a firm that measures its current share price relative to its per-share earnings (Nicholson, S. F.1960). The price-earnings ratio often called the $\mathrm{P} / \mathrm{E}$ ratio or price to earnings ratio, is a market prospect ratio that calculates the market value of a stock relative to its earnings by comparing the market price per share by the earnings per share.

The price-earnings ratio is normally calculated as the market value per share divided by earnings per share. In other words, the price-earnings ratio shows what the market is willing to pay for a stock based on its current earnings.

$$
\text { Price-to-Eanning Ratio }(P / E \text { Ratio })=\quad \frac{\text { Market Value Price per Share }}{\text { Earnings per } \text { Share }(E P S)}
$$

Normally, a high $\mathrm{P} / \mathrm{E}$ ratio implies that investors are anticipating higher earnings growth within the next years while firms with a lower P/E are expected lower growth (Ghaeli, 2017). Investors often use this ratio to evaluate what a stock's fair market value should be by predicting future earnings per share. Companies with higher future earnings are usually expected to issue higher dividends or have appreciating stock in the future.

There are two key drivers responsible for the increment in the $\mathrm{P} / \mathrm{E}$ ratio; the first one is rapid growth in Price-Earnings ratios and the second one is slower growth in dividend yields. Rapid growth in price-earnings ratios simply shows the strong confidence of existing investors in a company due to the favourable market-wide environment. On the other hand, slower growth in dividend yields shows the company's management strategies focusing on reinvestment by employing a bigger chunk of retained earnings. Hence, sometimes lower dividend yields give hope to investors to accumulate even better return in future and this situation leads to a higher stock price as well as higher P/E ratio. These findings are consistent with Myers's (1984) pecking order and stakeholder hypotheses of dividend behaviour. There is also evidence that the $\mathrm{P} / \mathrm{E}$ ratio is high when the price growth rate is high. This study indicates that a high $\mathrm{P} / \mathrm{E}$ ratio signals faster growth in short-term stock prices (Raymond Y. C. Tse., 2002).

Pankaj Kumar (2017), studied the influence of P/E ratio on the listed Indian automobile companies. The regression result showed a significant effect of $\mathrm{P} / \mathrm{E}$ on the share price of automobile companies.

Sanjeet Sharma (2011), conducted research on 115 listed companies of six different industries of India. Regression analysis showed that the $\mathrm{P} / \mathrm{E}$ ratio exerts a significant positive impact on the share price of the companies. Similarly, Taimur Sharif et. al., (2015), studied the effect of PE ratio along with other firm-specific variable and they found that $\mathrm{PE}$ ratio is one of the main driving factors for the upward price movement of stocks. On the other hand, Onyango Benedict Enrile (2018) and Budhi Suparnihgsih (2017), respectively found positive yet insignificant effect and no significant effect of $\mathrm{P} / \mathrm{E}$ ratio on the stock price. Similarly, AtyHerawati and Angger (2018) and George Gatheru Githinji (2011), observed no effect of the P/E ratio on the stock price.

The Asset-Growth Effect: There is a significant and negative relationship between asset growth and future stock returns in emerging markets. Watanabe et al. (2012) find a weaker asset-growth effect in emerging markets relative to developed markets. In the context of this study, the asset growth effect has been analyzed and investigated, with a focus on the global financial crisis of 2008 and compare the existence of the asset-growth effect between normal and crisis periods. Since the financial crisis has effects globally on emerged as well as 
emerging countries, our analysis on stocks traded in emerging markets provides the opportunity to identify whether mispricing or optimal investment explanation would find support in those countries. It has been observed that the asset-growth effect is stronger during the crisis period relative to more normal periods. During the peak year of the Global Financial Crisis, 2008, strong indicators have been found to support the existence of the asset growth effect during the crisis period, but not in other periods.

That points to a significant association between the asset-growth effect and the global financial crisis period. The logic is that an episode of crisis gives investors the possibility to improve their assessment of the real value of firms' investment even in those countries where the agency problems and asymmetric information are commonly assumed to be higher.

In particular, the negative relation between asset growth and subsequent taxes returns holds only for the subset of firms with low innovation potential. Innovation based firms with high asset growth not only do not suffer negative excess returns subsequent to asset growth but actually, earn significantly positive subsequent excess returns. In addition, the significantly positive interaction effect between asset growth and innovative capacity on subsequent stock returns is robust to the industry effect, the size and BTM effects, and the IE effect documented in Hirshleifer et al. (2012). Asset Growth in innovative Pharmaceutical companies driven by huge investments and aggressive M\&A strategy can generate new growth options.

Gross Domestic Product (GDP): Gross Domestic Product (GDP) is the prime reflector of a country's economic growth; it gives a clear view about the degree of growth in almost every type of industry of a country. The high tide of economic growth marks the high probability of higher cash flow and low probability of the firm's chances to bankrupt, which provides a good environment for higher profitability, investment and so on which in turn increases value and stock prices of firms. On the other hand, during the time of economic downturn, the situation turns upside down.

Economic growth occurs when an economy's productive capacity increases, which in turn is used to produce more goods and services. Economic growth is measured by an increase in the amount of goods and services that are produced in a country. Therefore, a growing economy produces more goods and services each successive time period. (Jhingan, M. 1997 Cited in Kampamba Shula (2017)).However, it is not always true that we get a correlation between GDP and stock return (www.wise-owl.com).

Inflation Rate: Inflation is always and everywhere a monetary phenomenon in the sense that it is and can be produced only by a more rapid increase in the quantity of money than in output. Empirically, the variability of inflation tends to increase with the level of inflation, reinforcing the negative effect of higher inflation on the quantity of money demanded (Friedman., M. 1987). Higher inflation generally decreases the purchasing power of individuals and companies that eventually produces a negative influence on productivity, profitability and stock price of firms. Firms operate in a high inflation environment have a lower degree of willingness to opt debt financing which disrupts long investment plans and short-term purchasing power of firms (Öztekin., Ö. (2015).

Interest Rate: Interest rates greatly affect a company's plan in fulfilling its capital needs, either by issuing equity securities or bonds. The low-interest rate will encourage investment and economic activity which generates a higher stock price as the result. (Thobarry, A. A. 2009 Cited in Kampamba Shula (2017). Similarly, Md. Gazi Salah Uddi and Md. Mahmudul Alam (2010) found an inverse relationship between the interest rate and share prices of listed companies at the Dhaka Stock Exchange. Low-interest rates will lead to lower borrowing costs since the borrower (the company) is charged to pay less interest. There is a negative relationship between the interest rate and borrowing capacity of the firm (Joeveer, K. (2013). Firm, Country and Macroeconomic Determinants of Capital Structure: Evidence from Transition Economics. Journal of Comparative Economics, 41(1), 294-308).

Corporate Tax: Reduction of government economic activity in the past 30 years in the wake of sweeping capitalism resulted in limiting both the scope and form of government taxation but the financial crisis of 2008 changed this paradigm, as it was expected from federal authorities to once again bail out the situation to restore calmness to markets. In this context, taxation became the most important tool of government policy (Renata Perić, LjubicaKordić, 2014).

In the aftermath of the financial crisis of 2008, many pointed out that the reason lies in the fact that too many firms had loaded up on debt while relying on only a thin layer of equity. The reason is straightforward: whereas equity can absorb a business downturn - profits fall, but the firm does not immediately fail - debt is less forgiving because creditors do not wait around to be paid (Mark Roe, 2013, World Economic Forum). The tax system that was skewed towards allowing, firms to use more debt than is safe. Tax deductions for interest 
payments encourage them to borrow which in turn resulted in more tax-induced lending from financial institutions. The tax reform measures, brought in after the global crisis, had both positive and negative impacts on the global pharmaceutical investment outlook. Opportunities to access new markets mitigate risk due to pricing pressures and patent expirations continued to be the main impetus for the new operating model.

- Corporate tax rates and repatriation as key drivers spurred M\&A activity by making more cash available.

- Many life sciences companies have chosen to keep their intellectual property (IP) rights offshore for tax reasons (Jeff Ellis and Dennis Howell, 2018).

- $\quad$ R\&D expenditures to boost new drug discovery and maintain a lucrative pipeline enjoyed cash infusions from various tax reforms. Counties like the US are also trying to retain intangible benefits by asking companies to amortize the cost of R\&D performed onshore and offshore rather than deduct it all immediately.

Exchange Rate: There is no theoretical consensus on the relationship between stock prices and exchange rates either. For instance, portfolio balance models of exchange rate determination postulate a negative relationship between stock prices and exchange rates and that the causation runs from stock prices to exchange rate. In contrast, a positive relationship between stock prices and exchange rates with the direction of causation running from exchange rates to stock prices can be explained as follows: domestic currency depreciation makes local firms more competitive, leading to an increase in their exports. This, in turn, raises their stock prices.

A weak or no association between stock prices and exchange rates can also be postulated. The factors/news that causes changes in exchange rates may be different from the factors that cause changes in stock prices. Under such a scenario, there should be no link between the said variables Muhammad, $N$ and Rasheed, A.,(2002).

Some studies have found a significant positive relationship between stock prices and exchange rates for instance Smith (1992); Solnik (1987)* and Aggarwal (1981)*, while others have reported a significant negative relationship between the two e.g., Soenen and Hennigar (1998)*. On the other hand, there are some studies that have found very weak or no association between stock prices and exchange rates, for instance, Franck and Young (1972); Bartov and Bodnor (1994)*. Note: *references are cited in Muhammad, $N$ and Rasheed, A., (2002)

\section{Methodology}

\subsection{Data Collection:}

The data for this research work has been collected from the different relevant secondary sources such as the annual stock price of companies collected from www.Investing.com, other internal data of companies, for instance ROE, EPS, DPS, DPR, P/E ratio, and asset from Thomson Router EKion Data Stream, Macroeconomic data such as GDP, Inflation Rate, etc from www.knoema.com, and Currency Exchange Rate from www.poundsterlinglive.com. Since this research study is related to the pharmaceutical industry of emerging and emerged markets, quantitative data of twenty listed companies selected from emerging market (India) and twenty listed companies form emerged market (USA, Germany, France, United Kingdom, and Switzerland) have been sampled and analyzed.

Two-panel data have been constructed, first one for the emerging market from the year 2008 to the year 2017 with 200 observations and the second one for the emerged market for the same period with 181 observations.

In this study, selected companies were chosen based on their home countries and stock prices of those companies, belonging to their home stock exchanges, were collected along with other firm-specific data, retrieved from Thomson Ekion data stream. Since stock prices, EPS, DPS, and Asset of every company were collected in their local currency units, the currencies have been converted into US dollars, for the sake of congruency.

The reason behind selecting twenty companies is because most of the mid-sized and small-sized companies of the emerged markets are privately held and not listed in stock exchanges. Similarly, due to many 
negative and unavailable values of Earnings per share and dividend per share respectively, only 181 observations were made for the emerged market companies.

\subsection{Research Methodology}

The multiple regression method has been employed in this study in order to understand the relationship between several independent variables and the dependent variable. The independent variables used in this study are namely ROE, EPS, DPS, DPR, PER, ASSET, GDPGR, INFR, INTR, CT, and EXCHR whereas the dependent variable is MPS. Moreover, panel data model is being used in current course of investigation. There are several reasons behind using panel data, such as higher number of informative data, higher level of divergence among data, lower chance of collinearity among variables and more degree of freedom, which contribute towards constructing a more efficient data model.

Four steps have been employed:

- Descriptive statistical analysis to obtain the overview of data in terms of mean, maximum, minimum, sum, standard deviation, kurtosis, and so on

- Correlation test has been employed to check the degree of Multicollinearity.

- The following are the two types of panel analytic models have been considered: (1) Fixed effect model and (2) Random effect model. The fixed effect model is the divergence across crosssectional units which can be represented in divergence in the constant term and the intercept term of the regression model varies across the cross sectional units whereas the random effect model, the individual effects are randomly dispersed across the cross-sectional units and in order to represent the individual effects, the regression model is specified with an intercept term which represents an overall constant term (Seddighi, 2000)

- In order to obtain better statistical model between Fixed Effect and Random Effect, the Hausman test has been used

- $\quad$ Fixed effect Panel data regression model has been used to investigate simulations and partial effect of independent variables on dependent variables

\subsection{Research Hypothesis}

This section aims at providing a specific, clear, and testable proposition or predictive statement about the possible outcome of this study based on various variables and relationships between them in the context of the Pharmaceutical industry. Specifying the research hypotheses is one of the most important steps in planning a quantitative research study and it typically states a priori expectation about the research outcome in research hypotheses, because the design of the research often is determined by the stated hypotheses.

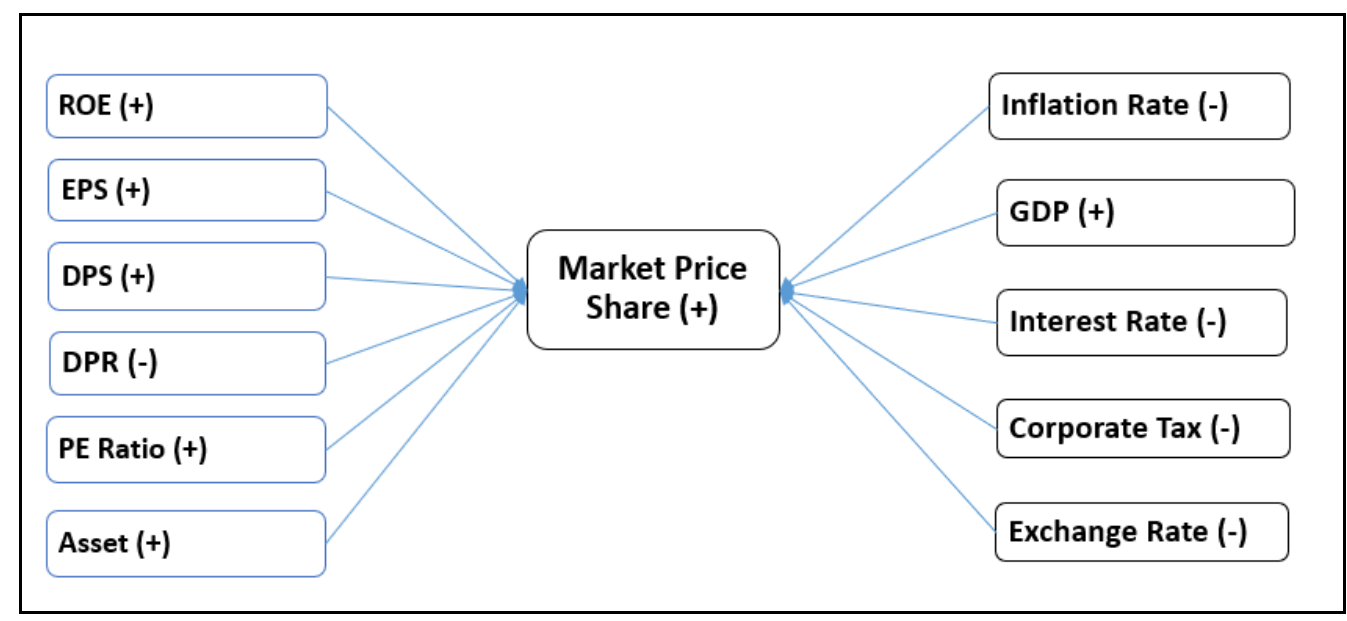

Figure 2: Conceptual Framework Figure 


\begin{tabular}{|c|c|c|c|c|c|c|}
\hline $\begin{array}{l}\text { Serial } \\
\text { Numbe } \\
\mathbf{r}\end{array}$ & $\begin{array}{l}\text { Variable } \\
\text { s }\end{array}$ & $\begin{array}{l}\text { Measureme } \\
\text { nt }\end{array}$ & $\begin{array}{l}\text { Expected } \\
\text { Hypothes } \\
\text { is }\end{array}$ & $\begin{array}{l}\text { Key Empirical } \\
\text { Studies in } \\
\text { support of } \\
\text { Expected } \\
\text { Hypothesis }\end{array}$ & $\begin{array}{l}\text { Key Empirical } \\
\text { Studies in } \\
\text { contrary to } \\
\text { Expected } \\
\text { Hypothesis } \\
\end{array}$ & $\begin{array}{l}\text { Key Empirical } \\
\text { Studies observed } \\
\text { no effect of } \\
\text { Expected } \\
\text { Hypothesis }\end{array}$ \\
\hline 1 & $\begin{array}{l}\text { Market } \\
\text { Price of } \\
\text { Share } \\
\text { (MPS) }\end{array}$ & $\begin{array}{l}\text { Annual } \\
\text { Closing } \\
\text { Market Price } \\
\text { of Share }\end{array}$ & & & & \\
\hline 2 & $\begin{array}{l}\text { Return on } \\
\text { Equity } \\
\text { (ROE) }\end{array}$ & $\begin{array}{l}\text { Net Income / } \\
\text { Shareholder } \\
\text { Equity }\end{array}$ & + & $\begin{array}{l}\text { KarnawiKamar } \\
(2017),\end{array}$ & $\begin{array}{l}\text { FitriSukmawati } \\
\text { and Innes Garsela } \\
(2016)\end{array}$ & $\begin{array}{l}\text { Haque and } \\
\text { Faruquee (2013), } \\
\text { Fouzan Al Qaisi } \\
\text { et. Al. (2016) }\end{array}$ \\
\hline 3 & $\begin{array}{l}\text { Earnings } \\
\text { Per Share } \\
\text { (EPS) }\end{array}$ & $\begin{array}{l}\text { (Net Income } \\
\text { - Dividends } \\
\text { on Preferred } \\
\text { Stocks) / } \\
\text { Avg. } \\
\text { Outstanding } \\
\text { Shares }\end{array}$ & + & $\begin{array}{l}\text { BudhiSuparnihgs } \\
\text { ih (2017), Ursula } \\
\text { Tamuntuan } \\
\text { (2015), etc }\end{array}$ & -------- & ------- \\
\hline 4 & $\begin{array}{l}\text { Dividend } \\
\text { Per Share } \\
\text { (DPS) }\end{array}$ & $\begin{array}{l}\text { Total } \\
\text { Dividends - } \\
\text { Special } \\
\text { Dividends } \\
\text { (If Any) / } \\
\text { Annual } \\
\text { Weighted } \\
\text { Average of } \\
\text { Outstanding } \\
\text { Shares } \\
\end{array}$ & + & $\begin{array}{l}\text { Onyango } \\
\text { Benedict Enrile } \\
(2018), \text { Sanjeet } \\
\text { Sharma (2011), } \\
\text { etc }\end{array}$ & $\begin{array}{l}\text { SebastianusLaure } \\
\text { ns (2018), } \\
\text { Hashemijoo. et.al } \\
\text { (2012) }\end{array}$ & ------------- \\
\hline 5 & $\begin{array}{l}\text { Dividend } \\
\text { Payout } \\
\text { Ratio } \\
\text { (DPR) }\end{array}$ & $\begin{array}{l}\text { Dividend Per } \\
\text { Share / } \\
\text { Earnings Per } \\
\text { Share }\end{array}$ & - & $\begin{array}{l}\text { Hunjra et. al. } \\
(2014)\end{array}$ & $\begin{array}{l}\text { Hasan M et. al. } \\
(2015), \text { Hossain } \\
\text { and A. H. M. } \\
\text { Asaduzzaman } \\
(2017)\end{array}$ & $\begin{array}{l}\text { Onyango Benedict } \\
\text { Enrile (2018) }\end{array}$ \\
\hline 6 & $\begin{array}{l}\text { Profit- } \\
\text { Earnings } \\
\text { Ratio } \\
\text { (PER) }\end{array}$ & $\begin{array}{l}\text { Market } \\
\text { Value Per } \\
\text { Share } \\
\text { /Earnings } \\
\text { Per Share }\end{array}$ & + & $\begin{array}{l}\text { Pankaj Kumar } \\
\text { (2017), Sanjeet } \\
\text { Sharma (2011) }\end{array}$ & ----------- & $\begin{array}{l}\text { Aty Herawati and } \\
\text { Angger (2018), } \\
\text { George Gatheru } \\
\text { Githinji (2009) }\end{array}$ \\
\hline 7 & $\begin{array}{l}\text { Asset } \\
\text { (LASSE } \\
\text { T) } \\
\end{array}$ & $\begin{array}{l}\text { Company's } \\
\text { Total Asset }\end{array}$ & + & & & \\
\hline 8 & $\begin{array}{l}\text { Gross } \\
\text { Domestic } \\
\text { Product } \\
\text { Growth } \\
\text { Rate } \\
\text { (GDPGR } \\
\text { ) }\end{array}$ & $\begin{array}{l}\text { Annual GDP } \\
\text { Growth Rate } \\
\text { of } \\
\text { Countries }\end{array}$ & + & $\begin{array}{l}\text { Jhingan, M. } \\
\text { (1997) }\end{array}$ & -------- & $\begin{array}{l}\text { https://www.wise- } \\
\text { owl.com/investme } \\
\text { nt-education/is- } \\
\text { there-a- } \\
\text { correlation- } \\
\text { between-gdp- } \\
\text { growth-and-stock- } \\
\text { market-returns }\end{array}$ \\
\hline 9 & $\begin{array}{l}\text { Inflation } \\
\text { Rate } \\
\text { (INFR) }\end{array}$ & $\begin{array}{l}\text { Annual } \\
\text { Inflation } \\
\text { Rate of } \\
\text { Countries }\end{array}$ & - & $\begin{array}{l}\text { Milton Friedman } \\
\text { (1987), Öztekin., } \\
\text { Ö. (2015) }\end{array}$ & ---------------- & -------- \\
\hline 10 & $\begin{array}{l}\text { Interest } \\
\text { Rate } \\
\text { (INTR) }\end{array}$ & $\begin{array}{l}\text { Annual Real } \\
\text { Interest Rate } \\
\text { of }\end{array}$ & - & $\begin{array}{l}\text { Md. Gazi } \\
\text { SalahUddi and } \\
\text { Md. Mahmudul }\end{array}$ & --------------- & ---------- \\
\hline
\end{tabular}




\begin{tabular}{|l|l|l|l|l|l|l|}
\hline & & Countries & $\begin{array}{l}\text { Alam (2010), } \\
\text { Thobarry, A. A. } \\
(2009)\end{array}$ & & \\
\hline $\mathbf{1 1}$ & $\begin{array}{l}\text { Corporate } \\
\text { Tax (CT) }\end{array}$ & $\begin{array}{l}\text { Annual } \\
\text { Corporate } \\
\text { Tax of } \\
\text { Countries }\end{array}$ & - & Mark Roe, 2013 & & \\
\hline $\mathbf{1 2}$ & $\begin{array}{l}\text { Exchange } \\
\text { Rate } \\
\text { (EXCHR }\end{array}$ & $\begin{array}{l}\text { Countries' } \\
\text { Exchange } \\
\text { Rate on the } \\
\text { Last day of } \\
\text { Financial } \\
\text { Year of } \\
\text { Companies }\end{array}$ & - & $\begin{array}{l}\text { Soenen and } \\
\text { Hennigar (1998) }\end{array}$ & $\begin{array}{l}\text { Solnik (1987) } \\
\text { and Aggarwal } \\
\text { (1981 }\end{array}$ & $\begin{array}{l}\text { Franck and Young } \\
(1972)\end{array}$ \\
\hline
\end{tabular}

Table1: Summary Table of Variables, Expected Hypothesis, and Studied Previous results

\subsection{The Model}

$M P S_{i t}=\beta_{0}+\beta_{1} R_{\text {OE }}{ }_{i t}+\beta_{2}$ EPS $_{i t}+\beta_{3}$ DPS $_{i t}+\beta_{4} D P R_{i t}+\beta_{5} P E R_{i t}+\beta_{6} L_{A S S E T}+\beta_{7}$ GDPGR $_{i t}+\beta_{8}$ INFR $^{2}$ ${ }_{i t}+\beta_{9} I N T R_{i t}+\beta_{10} C T_{i t}+\beta_{11} E_{X C H R}+\emptyset_{i t}$

- $\quad$ MPS $_{\text {it }}=$ Market Prices of Share for the Pharmaceutical Companies during the period $\mathrm{t}$

- $\quad \mathbf{R O E}_{\text {it }}=$ Effect of Return on Equity (ROE) on MSP of the Pharmaceutical Companies during the period $t$

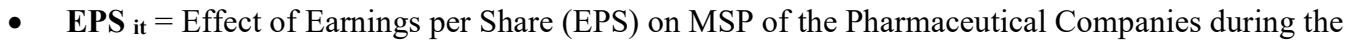
period $t$

- $\quad$ DPS $_{\text {it }}=$ Effect of Dividend per Share (DPS) on MSP of the Pharmaceutical Companies during the period $\mathrm{t}$

- $\quad$ DPR $_{\text {it }}=$ Effect of Dividend Pay Ratio (DPR) on MSP of the Pharmaceutical Companies during the period $\mathrm{t}$

- $\quad$ PER $_{\text {it }}=$ Effect of Price Earnings Ratio (PER) on MSP of the Pharmaceutical Companies during the period $\mathrm{t}$

- $\quad$ ASSET $_{\text {it }}=$ Effect of Log of Total Assets (LASSET) on MSP of the Pharmaceutical Companies during the period $t$

- $\quad$ GDPGR $_{\mathrm{it}}=$ Effect of GDP (GDPGR) on MSP of the Pharmaceutical Companies during the period $\mathrm{t}$

- $\quad$ INFR it= Effect of Inflation Rate (INFR) on MSP of the Pharmaceutical Companies during the period $t$

- $\quad$ INTR $_{\text {it }}=$ Effect of Interest Rate (INTR) on MSP of the Pharmaceutical Companies during the period $t$

- $\quad \mathbf{C T}_{\text {it }}=$ Effect of Corporate Tax (CT) on MSP of the Pharmaceutical Companies during the period $\mathrm{t}$

- $\quad$ EXCHR it $=$ Effect of Currency Exchange Rate (EXCHR) on MSP of the Pharmaceutical Companies during the period $\mathrm{t}$

$\boldsymbol{\beta}_{\mathbf{0}}=$ Intercept

$\boldsymbol{\beta}_{\mathbf{1}}-\boldsymbol{\beta}_{11}=$ Coefficient parameters

$\boldsymbol{\emptyset}_{\text {it }}=$ error term 


\section{Findings and Analysis}

\subsection{Descriptive Statistics Analysis}

\begin{tabular}{|c|c|c|c|c|c|c|c|c|c|c|c|c|}
\hline & MPS & ROE & EPS & DPS & DPR & PER & LASSET & GDPGR & INFR & INTR & CT & EXCHR \\
\hline Mean & 5.017152 & 0.214122 & 0.263590 & 0.047207 & 0.208234 & 20.55632 & 5.780051 & 0.070600 & 0.077300 & 0.068960 & 0.338670 & 53.86850 \\
\hline Median & 3.019759 & 0.186500 & 0.194419 & 0.034325 & 0.200525 & 18.02119 & 5.610477 & 0.069000 & 0.092500 & 0.073200 & 0.339900 & 52.62000 \\
\hline Maximum & 32.14881 & 0.816000 & 1.572172 & 0.301864 & 1.568615 & 275.6667 & 9.155685 & 0.103000 & 0.110000 & 0.080000 & 0.346100 & 66.25500 \\
\hline Minimum & 0.135349 & -0.070000 & 0.009611 & 0.000000 & 0.000000 & 0.736363 & 3.319507 & 0.039000 & 0.036000 & 0.052500 & 0.324400 & 39.98000 \\
\hline Std. Dev. & 5.381683 & 0.118203 & 0.231940 & 0.040955 & 0.160171 & 22.95119 & 1.378394 & 0.016529 & 0.025755 & 0.009534 & 0.007619 & 8.773534 \\
\hline Skewness & 2.114633 & 1.416436 & 2.656942 & 2.318320 & 4.871247 & 7.495629 & 0.070622 & 0.061060 & -0.407024 & -0.467803 & -1.027661 & -0.031573 \\
\hline Kurtosis & 8.321841 & 6.664292 & 13.18731 & 11.73509 & 39.16005 & 79.64759 & 2.240334 & 3.005369 & 1.491282 & 1.722949 & 2.725734 & 1.646541 \\
\hline Jarque-Bera & 385.0724 & 178.7683 & 1100.156 & 815.0016 & 11687.21 & 50829.93 & 4.975352 & 0.124520 & 24.49088 & 20.88515 & 35.82978 & 15.29866 \\
\hline Probability & 0.000000 & 0.000000 & 0.000000 & 0.000000 & 0.000000 & 0.000000 & 0.083103 & 0.939639 & 0.000005 & 0.000029 & 0.000000 & 0.000476 \\
\hline Sum & 1003.430 & 42.82440 & 52.71798 & 9.441383 & 41.64673 & 4111.265 & 1156.010 & 14.12000 & 15.46000 & 13.79200 & 67.73400 & 10773.70 \\
\hline Sum Sq. Dev. & 5763.540 & 2.780413 & 10.70540 & 0.333786 & 5.105326 & 104824.6 & 378.0942 & 0.054368 & 0.132002 & 0.018088 & 0.011552 & 15318.00 \\
\hline Observations & 200 & 200 & 200 & 200 & 200 & 200 & 200 & 200 & 200 & 200 & 200 & 200 \\
\hline
\end{tabular}

\section{Table2: Results Descriptive Statistics Analysis of Indian Pharmaceutical companies (Processed by} EViews-10)

\begin{tabular}{|c|c|c|c|c|c|c|c|c|c|c|c|c|}
\hline & MPS & ROE & EPS & DPS & DPR & PER & LASSET & GDPGR & INFR & INTR & CT & EXCHR \\
\hline Mean & 182.5609 & 0.103425 & 2.401576 & 1.345293 & 0.868461 & 172.6613 & 8.820834 & 0.012310 & 0.095880 & 0.005643 & 0.307701 & 0.909303 \\
\hline Median & 42.15102 & 0.143000 & 1.922450 & 1.119050 & 0.431267 & 17.55490 & 9.940290 & 0.017000 & 0.015000 & 0.002500 & 0.341500 & 1.000000 \\
\hline Maximum & 3789.540 & 1.030000 & 17.26635 & 8.345960 & 80.00000 & 7233.280 & 12.26881 & 0.039000 & 1.650000 & 0.039500 & 0.350000 & 1.064100 \\
\hline Minimum & 1.620000 & -4.647000 & -5.710000 & 0.000000 & -10.94737 & -497.1429 & 3.081910 & -0.056000 & -0.011000 & -0.007500 & 0.177700 & 0.605000 \\
\hline Std. Dev. & 559.6947 & 0.413980 & 3.588705 & 1.612761 & 6.013378 & 700.1737 & 2.530846 & 0.016686 & 0.357660 & 0.007692 & 0.063275 & 0.130422 \\
\hline Skewness & 4.698629 & -7.659486 & 1.383203 & 2.474909 & 12.65399 & 6.505117 & -0.520661 & -1.686224 & 4.120806 & 1.835959 & -1.242271 & -0.964057 \\
\hline Kurtosis & 25.29681 & 88.33408 & 6.430707 & 10.17754 & 167.6029 & 57.32034 & 1.968180 & 5.564488 & 18.00747 & 7.947771 & 2.812989 & 2.350414 \\
\hline Jarque-Bera & 4878.801 & 62638.14 & 161.8562 & 576.4683 & 209165.2 & 25869.71 & 17.90837 & 149.5834 & 2442.903 & 316.3618 & 51.73272 & 34.49657 \\
\hline Probability & 0.000000 & 0.000000 & 0.000000 & 0.000000 & 0.000000 & 0.000000 & 0.000129 & 0.000000 & 0.000000 & 0.000000 & 0.000000 & 0.000000 \\
\hline Sum & 36512.18 & 20.68508 & 480.3152 & 244.8433 & 157.1914 & 34359.60 & 1764.167 & 2.462000 & 19.17600 & 1.128600 & 61.54020 & 181.8605 \\
\hline Sum Sq. Dev. & 62338370 & 34.10449 & 2562.882 & 470.7808 & 6508.929 & 97068151 & 1274.631 & 0.055403 & 25.45623 & 0.011775 & 0.796738 & 3.384965 \\
\hline Observations & 200 & 200 & 200 & 182 & 181 & 199 & 200 & 200 & 200 & 200 & 200 & 200 \\
\hline
\end{tabular}

Table3: Results Descriptive Statistics Analysis of US \& European Pharmaceutical companies (Processed by EViews-10)

For Indian pharmaceutical companies, Table 2 shows descriptive statistics analysis of 200 observations of for one dependent variable and twelve independent variables. In the case of US and European pharmaceutical companies, Table 3 shows descriptive statistics analysis of DPS and DPR with 181 observations, PER with 199 observations and rest of variables with 200 observations.

Descriptive statistical analysis of MPS for US and European pharmaceutical companies reflects a key difference from Indian pharmaceutical companies by having a huge gap between the minimum (1.620000) and maximum (3789.540) MSP value, much higher mean (182.5609), and standard deviation (559.6947). This result shows that few companies have had very high share price throughout the taken time period. Similarly, for US and European pharmaceutical companies, other variables such as ROE, EPS, DPR, and PER are swinging from higher negative value for the minimum to higher positive values for maximum. Moreover, other statistical parameters for instance mean and standard deviation are also showing value on the higher side. The reason behind this surge could be attributed to a much better performance of few companies over others.

In the case of Indian pharmaceutical companies, MSP variable has a moderate range from minimum (0.135349) to maximum (32.14881) with mean of 5.017152 and standard deviation 5.381683. Similarly, other variables such as EPS, DPS, DPR, LASSET, and PER are also showing moderate variation in values for minimum, maximum, mean, and standard deviation. Results show that throughout the observed time period, most of the Indian pharmaceutical companies in this study had performed in a reasonable manner.

Descriptive statistical analysis of Indian as well as US and European pharmaceutical companies also depicts that dependent variable (MPS) and many independent variables have skewness greater than 1, which 
shows high positive skewness whereas few variables have skewness less than -1 , which shows high negative skewness. Both scenarios explain that data is not symmetrical. However, few variables have positive or negative skewness near to 0 which reflects that these variables have better symmetrical distribution than their peers.

Since all variables have Kurtosis value more than 0 , it infers that data distribution of variables has a heavier tail, called leptokurtic distribution. Furthermore, Kurtosis results also show that variables are not distributed symmetrically. In case of Indian pharmaceutical companies, Jarque-Bera test for checking the symmetrical distribution of variables reflects that except LASSET and GDPGR, other variables have probability value less than $5 \%$, which shows that variables are not normally distributed. However, in case of US and European pharmaceutical companies, Jarque- Bera test for checking the symmetrical distribution of variables shows each variable having probability value less than $5 \%$, indicating that variables are not normally distributed.

\subsection{Correlation Analysis}

\begin{tabular}{|cccccccccccc|}
\hline & ROE & EPS & DPS & DPR & PER & LASSET & GDPGR & INFR & INTR & CT & EXCHR \\
ROE & 1.000000 & 0.480539 & 0.263484 & -0.136942 & -0.161969 & 0.221006 & -0.055083 & 0.104760 & 0.052074 & -0.074084 & -0.156407 \\
EPS & 0.480539 & 1.000000 & 0.723002 & -0.207805 & -0.075762 & 0.128634 & -0.024787 & -0.269697 & 0.061018 & 0.091441 & 0.249788 \\
DPS & 0.263484 & 0.723002 & 1.000000 & 0.124588 & -0.053951 & -0.013739 & 0.034329 & -0.222783 & 0.061242 & 0.098134 & 0.229039 \\
DPR & -0.136942 & -0.207805 & 0.124588 & 1.000000 & 0.591633 & -0.272037 & -0.000456 & 0.097938 & 0.088633 & -0.084579 & -0.021667 \\
PER & -0.161969 & -0.075762 & -0.053951 & 0.591633 & 1.000000 & 0.093046 & 0.077463 & -0.320882 & 0.059757 & 0.175649 & 0.312853 \\
LASSET & 0.221006 & 0.128634 & -0.013739 & -0.272037 & 0.093046 & 1.000000 & -0.000143 & -0.168783 & 0.038952 & 0.060398 & 0.167452 \\
GDPGR & -0.055083 & -0.024787 & 0.034329 & -0.000456 & 0.077463 & -0.000143 & 1.000000 & -0.044101 & -0.584998 & 0.289197 & 0.185959 \\
INFR & 0.104760 & -0.269697 & -0.222783 & 0.097938 & -0.320882 & -0.168783 & -0.044101 & 1.000000 & -0.009365 & -0.643132 & -0.842999 \\
INTR & 0.052074 & 0.061018 & 0.061242 & 0.088633 & 0.059757 & 0.038952 & -0.584998 & -0.009365 & 1.000000 & -0.457664 & -0.049103 \\
CT & -0.074084 & 0.091441 & 0.098134 & -0.084579 & 0.175649 & 0.060398 & 0.289197 & -0.643132 & -0.457664 & 1.000000 & 0.582928 \\
EXCHR & -0.156407 & 0.249788 & 0.229039 & -0.021667 & 0.312853 & 0.167452 & 0.185959 & -0.842999 & -0.049103 & 0.582928 & 1.000000 \\
\hline
\end{tabular}

Table4: Results Correlation Analysis of Indian Pharmaceutical companies (Processed by EViews-10)

\begin{tabular}{|cccccccccccc}
\hline & ROE & EPS & DPS & DPR & PER & LASSET & GDPGR & INFR & INTR & CT & EXCHR \\
ROE & 1.000000 & 0.420612 & 0.329006 & -0.003524 & 0.036733 & 0.374162 & 0.100853 & -0.019127 & -0.147015 & -0.226923 & -0.025139 \\
EPS & 0.420612 & 1.000000 & 0.655097 & -0.040519 & -0.120871 & 0.447783 & 0.078046 & -0.074960 & -0.277622 & -0.391630 & 0.200210 \\
DPS & 0.329006 & 0.655097 & 1.000000 & -0.008333 & -0.067289 & 0.556479 & 0.073373 & -0.055722 & -0.261344 & -0.494865 & 0.180711 \\
DPR & -0.003524 & -0.040519 & -0.008333 & 1.000000 & 0.265700 & -0.003076 & 0.055695 & -0.009277 & 0.049829 & 0.017572 & -0.072630 \\
PER & 0.036733 & -0.120871 & -0.067289 & 0.265700 & 1.000000 & -0.031576 & 0.090410 & -0.034270 & 0.026866 & -0.292712 & -0.427684 \\
LASSET & 0.374162 & 0.447783 & 0.556479 & -0.003076 & -0.031576 & 1.000000 & 0.145368 & 0.072950 & -0.180310 & -0.110412 & 0.332583 \\
GDPGR & 0.100853 & 0.078046 & 0.073373 & 0.055695 & 0.090410 & 0.145368 & 1.000000 & 0.175232 & -0.271363 & -0.080916 & 0.153838 \\
INFR & -0.019127 & -0.074960 & -0.055722 & -0.009277 & -0.034270 & 0.072950 & 0.175232 & 1.000000 & -0.054430 & 0.158937 & 0.143092 \\
INTR & -0.147015 & -0.277622 & -0.261344 & 0.049829 & 0.026866 & -0.180310 & -0.271363 & -0.054430 & 1.000000 & 0.263986 & -0.327848 \\
CT & -0.226923 & -0.391630 & -0.494865 & 0.017572 & -0.292712 & -0.110412 & -0.080916 & 0.158937 & 0.263986 & 1.000000 & 0.165459 \\
EXCHR & -0.025139 & 0.200210 & 0.180711 & -0.072630 & -0.427684 & 0.332583 & 0.153838 & 0.143092 & -0.327848 & 0.165459 & 1.000000 \\
\hline
\end{tabular}

Table5: Results Correlation Analysis of US \& European Pharmaceutical companies (Processed by EViews-10)

Based on table 4 and 5, the value of correlation coefficient among independent variables of Indian as well as US and European pharmaceutical companies can be seen. In the correlation matrix, a correlation coefficient shows the extent to which one variable is correlated with others. A positive correlation means any increment in one variable causes an increment in other variable and a decrement in one variable causes a decrement in other variable similarly in case of negative correlation it is vice versa i.e. an increment in one variable causes a decrement in other variables.

In table 4 , the correlation matrix of Indian pharmaceutical companies depicts the higher correlation between few variables for instance EPS has highest positive correlation value (0.723002) with DPS followed by a positive correlation value $(0.591633)$ between DPR and PER. However, the highest negative correlation value $(-0.842999)$ observed between INFR and EXCHR.

The Correlation matrix of US and European pharmaceutical companies in Table 5, EPS has the highest positive correlation with DPS with a correlation value of (0.655097). The second highest correlation in this matrix is the positive correlation value $(0.556479)$ between DPS with LASSET.

Multicollinearity does not affect the properties of the OLS estimators. The estimator remains unbiased and efficient. But the fact is that when multicollinearity is present in the data then the OLS estimators are imprecisely estimated (Paul). Since seriousness of multicollinearilty in dataset can be measured through the 
degree of correlation among variables, generally, highest degree of accepted correlation between two variables should be less than 0.80 (Edhi, A., 2017). By analyzing the correlation matrices of both markets, it can be inferred that of the degree of correlation among most variables is less than 0.80 . However, negative correlation value (-0.842999) is observed between INFR and EXCHR for Indian pharmaceutical market in Table 4 whereas and positive correlation value (0.143092) is observed between INFR and EXCHR for European pharmaceutical market. Since this study is primarily focusing on comparative analysis between two markets while keeping type and number of variables intact in both sides, this higher correlation between INFR and EXCHR for Indian pharmaceutical market in Table 4 has been overlooked.

\subsection{Regression Analysis}

\section{F-TEST}

The $\mathrm{F}$ test is carried out to verify whether the independent variables ROE, EPS, DPS, DPR, PER, LASSET, GDPGR, INFR, INTR, CT, and EXCHR combined, can significantly influence the dependent variable MSP of companies.

Hypothesis: There is a simultaneous significant influence of independent variables on the dependent variable.

\begin{tabular}{|c|c|}
\hline Indian Pharmaceutical companies & US and European Pharmaceutical companies \\
\hline $\begin{array}{l}\text { Result of the F test (simultaneous coefficient test) } \\
\text { shows that F-statistic of } 32.32335 \text { with significance } \\
\text { below }(0.000000<0.05 \text { ). It can be concluded that } \\
\text { together with ROE, EPS, DPS, DPR, PER, LASSET, } \\
\text { GDPGR, INFR, INTR, CT, and EXCHR have a } \\
\text { simultaneous significant effect on MSP of Indian } \\
\text { Pharmaceutical Companies. } \\
\text { Hypothesis Accepted }\end{array}$ & $\begin{array}{l}\text { Result of the F test (simultaneous coefficient test) } \\
\text { shows that F-statistic of } 99.05622 \text { with significance } \\
\text { below }(0.000000<0.05) \text {. It can be concluded that } \\
\text { together with ROE, EPS, DPS, DPR, PER, LASSET, } \\
\text { GDPGR, INFR, INTR, CT, and EXCHR have a } \\
\text { simultaneous significant effect on MSP of US and } \\
\text { European Pharmaceutical Companies. } \\
\text { Hypothesis Accepted }\end{array}$ \\
\hline
\end{tabular}

\section{Regression Result Summary}

\begin{tabular}{|c|c|c|c|c|}
\hline \multicolumn{5}{|c|}{\begin{tabular}{|l} 
Dependent Variable: MPS \\
Method: Panel Least Squares \\
Date: $04 / 22 / 19$ Time: $21: 17$ \\
Sample: 20082017 \\
Periods included: 10 \\
Cross-sections included: 20 \\
Total panel (balanced) observations: 200
\end{tabular}} \\
\hline Variable & Coefficient & Std. Error & $\mathrm{t}$-Statistic & Prob. \\
\hline C & -16.60750 & 16.20192 & -1.025032 & 0.3068 \\
\hline ROE & -8.035798 & 3.537531 & -2.271584 & 0.0244 \\
\hline EPS & 7.059722 & 2.073999 & 3.403919 & 0.0008 \\
\hline DPS & 61.00841 & 9.119055 & 6.690212 & 0.0000 \\
\hline DPR & -7.331832 & 2.236580 & -3.278144 & 0.0013 \\
\hline PER & 0.061568 & 0.013690 & 4.497197 & 0.0000 \\
\hline LASSET & 2.031314 & 0.975845 & 2.081595 & 0.0389 \\
\hline GDPGR & -1.596778 & 12.73396 & -0.125395 & 0.9004 \\
\hline INFR & -27.03355 & 15.69895 & -1.721998 & 0.0869 \\
\hline INTR & -15.50890 & 25.39091 & -0.610805 & 0.5421 \\
\hline CT & 37.90745 & 36.99307 & 1.024718 & 0.3070 \\
\hline EXCHR & -0.045328 & 0.038517 & -1.176839 & 0.2409 \\
\hline \multicolumn{5}{|c|}{ Effects Specification } \\
\hline \multicolumn{5}{|c|}{ Cross-section fixed (dummy variables) } \\
\hline R-squared & 0.851585 & \multirow{7}{*}{\multicolumn{2}{|c|}{$\begin{array}{l}\text { Mean dependent var } \\
\text { S.D. dependent var } \\
\text { Akaike info criterion } \\
\text { Schwarz criterion } \\
\text { Hannan-Quinn criter. } \\
\text { Durbin-Watson stat }\end{array}$}} & 5.017152 \\
\hline Adjusted R-squared & 0.825239 & & & 5.381683 \\
\hline S.E. of regression & 2.249779 & & & 4.601123 \\
\hline Sum squared resid & 855.3947 & & & 5.112362 \\
\hline Log likelihood & -429.1123 & & & 4.808013 \\
\hline F-statistic & 32.32335 & & & 1.564283 \\
\hline Prob(F-statistic) & 0.000000 & & & \\
\hline
\end{tabular}

Figure 4: Regression Result of Panel Data of Indian Pharmaceutical companies (Processed by EViews-10) Regression result of panel data of Indian pharmaceutical companies summarizes the regression test model in the following sections.

The regression output summary of Indian pharmaceutical companies revealed an R-squared value of 0.851585 which means that $85.1585 \%$ of the variation in the market share price of Indian pharmaceutical companies can be explicated by the independent variables included in the current study. Result of the F-test 
(simultaneous coefficient test) also shows that F-statistic value of 32.32335 with significance below $(0.000000<0.05)$ validates the inclusive simultaneous effect of all independent variables on the market price of a share of Indian pharmaceutical companies.

ROE for Indian Pharmaceutical companies has the negative coefficient value of -8.035798 and probability $(0.0244<0.05)$, which implies that the ROE has a significant negative effect on the MSP that is why H0 can be deemed rejected. This result supports previous studies of Fitri Sukmawati and Innes Garsela (2016).

Independent variable EPS with positive coefficient value of 7.059722 and probability value of $(0.0008<0.05)$ reflects that EPS has a significant positive effect on MSP of Indian pharmaceutical companies and thus H1can be deemed validated, which falls in line with the previous studies of Budhi Suparnihgsih (2017), Ursula Tamuntuan (2015).

Similarly, the regression output of DPS for Indian pharmaceutical companies gives a positive coefficient value of 61.00841 with a probability value of $(0.0000<0.05)$. Therefore, DPS can be considered to have a significant positive effect on the market share price which ratifies H2and supports previous studies of Onyango Benedict Enrile (2018), Sanjeet Sharma (2011), etc.

However, Regression output of DPR has the negative coefficient value of -7.331832 and probability value of $(0.0013<0.05)$ which depicts DPR with the significant negative effect on the stock price that means $\mathrm{H} 3$ is accepted and supports previous studies of Hunjra et. al.(2014). Regression output indicates that the estimation result of PER for Indian pharmaceutical companies shows a positive coefficient value of 0.061568 with a probability value of $(0.0000<0.05)$. It reflects that the PER has a significant positive effect on the market share price, which is in line with H4and supports previous studies of Pankaj Kumar (2017), Sanjeet Sharma (2011).

Similarly, Regression output result of LASSET with positive coefficient value of 2.031314 and probability value lower than the specified significance level of $5 \%(0.0389<0.05)$, reflects that the LASSET has a significant positive effect on the stock price of Indian Pharmaceutical companies, hence it can be concluded that $\mathrm{H} 5$ is accepted.

Regression result of macroeconomic variables such as GDPGR, INFR, INTR, CT, and EXCHR doesn't show any significant effect on the market share price of Indian pharmaceutical companies. Hence, hypothesisH6, $\mathrm{H} 7, \mathrm{H} 8, \mathrm{H} 9$, and $\mathrm{H} 10$ are rejected.

\begin{tabular}{|c|c|c|c|c|}
\hline \multicolumn{5}{|c|}{$\begin{array}{l}\text { Dependent Variable: MPS } \\
\text { Method: Panel Least Squares } \\
\text { Date: } 04 / 22 / 19 \text { Time: } 21: 56 \\
\text { Sample: } 20082017 \\
\text { Periods included: } 10 \\
\text { Cross-sections included: } 20 \\
\text { Total panel (unbalanced) observations: } 181\end{array}$} \\
\hline Variable & Coefficient & Std. Error & t-Statistic & Prob. \\
\hline C & 1759.451 & 454.4975 & 3.871201 & 0.0002 \\
\hline ROE & 24.38475 & 36.24807 & 0.672718 & 0.5022 \\
\hline EPS & 3.928813 & 6.061408 & 0.648168 & 0.5179 \\
\hline DPS & 33.59069 & 31.44775 & 1.068143 & 0.2872 \\
\hline DPR & -3.617106 & 2.025520 & -1.785767 & 0.0762 \\
\hline PER & 0.112454 & 0.026697 & 4.212300 & 0.0000 \\
\hline LASSET & -21.14702 & 27.00078 & -0.783201 & 0.4347 \\
\hline GDPGR & -51.14591 & 688.0880 & -0.074330 & 0.9408 \\
\hline INFR & 14.50280 & 35.55964 & 0.407844 & 0.6840 \\
\hline INTR & 2468.204 & 1683.991 & 1.465687 & 0.1448 \\
\hline CT & -7053.961 & 1062.856 & -6.636798 & 0.0000 \\
\hline EXCHR & 743.9563 & 221.1875 & 3.363465 & 0.0010 \\
\hline \multicolumn{5}{|c|}{ Effects Specification } \\
\hline \multicolumn{5}{|c|}{ Cross-section fixed (dummy variables) } \\
\hline R-squared & & \multirow{6}{*}{\multicolumn{2}{|c|}{$\begin{array}{l}\text { Mean dependent var } \\
\text { S.D. dependent var } \\
\text { Akaike info criterion } \\
\text { Schwarz criterion } \\
\text { Hannan-Quinn criter. } \\
\text { Durbin-Watson stat }\end{array}$}} & 192.5727 \\
\hline Adjusted R-squared & 0.942339 & & & 586.6521 \\
\hline S.E. of regression & 140.8712 & & & 12.88825 \\
\hline Sum squared resid & 2976705. & & & 13.43606 \\
\hline Log likelihood & -1135.387 & & & 13.11034 \\
\hline F-statistic & 99.05622 & & & 0.412744 \\
\hline Prob(F-statis tic) & 0.000000 & & & \\
\hline
\end{tabular}

Figure 5: Regression Result of Panel Data of US and European Pharmaceutical companies (Processed by EViews-10) 
Regression result of panel data of US and European pharmaceutical companies summarizes the regression test model in the following sections.

The regression output summary of US and European pharmaceutical companies revealed an R-squared value of 0.951949 which means that $95.1949 \%$ of the variation in the market share price of US and European pharmaceutical companies can be explicated by the independent variables included in the current study. Result of the F-test (simultaneous coefficient test) also shows that F-statistic value of 99.05622 with significance below $(0.000000<0.05)$ supporting the inclusive simultaneous effect of all independent variables on the market price of a share of US and European pharmaceutical companies.

In the case of US and European pharmaceutical companies, most of the microeconomic variables such as ROE, EPS, DPS, DPR, and LASSAT don't have any significant effect on the market share price of US and European pharmaceutical companies. Hence, hypothesis $\mathrm{H} 0, \mathrm{H} 1, \mathrm{H} 2, \mathrm{H} 3$, and $\mathrm{H} 5$ are rejected. However, microeconomic variable namely PER shows a positive and significant effect on the market share price of US and European pharmaceutical companies with a coefficient value of 0.076573 and probability value $(0.0000<0.05)$ respectively. Therefore, Hence, H4 is accepted and the result supports previous studies of Pankaj Kumar (2017), Sanjeet Sharma (2011).

Regression result of macroeconomic variables such as GDPGR, INFR, and INTR don't show any significant effect on the market share price of US and European pharmaceutical companies. Hence, hypothesis H6, H7, and H8, are rejected. However, macroeconomic variables such as CT and EXCHR for US and European companies show the negative coefficient value of -7053.961 and positive coefficient 743.9563 respectively, while having probability value of $(0.0000>0.05)$ for both variables. This result shows that $\mathbf{C T}$ and EXCHR have significant negative effect and positive effect respectively on the market share price of US and European pharmaceutical companies. Hence, hypothesis H9 is accepted which supports the previous study of Mark Roe (2013), whereas hypothesis H10 is rejected and supports the precious study of Solnik (1987) and Aggarwal (1981) and refutes the previous study done by Soenen and Hennigar (1998).

\begin{tabular}{|c|c|c|c|c|c|c|c|c|}
\hline & \multicolumn{4}{|c|}{ Indian Pharmaceutical companies } & \multicolumn{4}{|c|}{ US and European Pharmaceutical companies } \\
\hline $\begin{array}{l}\mathbf{S} . \\
\mathbf{N}\end{array}$ & $\begin{array}{l}\text { Name of } \\
\text { Variable } \\
\text { s }\end{array}$ & $\begin{array}{l}\text { Coefficien } \\
\mathrm{t} \\
\text { value }\end{array}$ & $\begin{array}{l}\text { Significance } \\
\text { level }\end{array}$ & Result & $\begin{array}{l}\text { Name of } \\
\text { Variable } \\
\text { s }\end{array}$ & $\begin{array}{l}\text { Coefficient } \\
\text { value }\end{array}$ & $\begin{array}{l}\text { Significance } \\
\text { level }\end{array}$ & Result \\
\hline (a) & ROE & -8.035798 & $\begin{array}{l}(0.0244 \\
<0.05)\end{array}$ & $\begin{array}{l}\text { Significan } \\
t \text { negative } \\
\text { effect. } \mathrm{Ho} \\
\text { Rejected }\end{array}$ & $\mathrm{ROE}$ & 24.38475 & $\begin{array}{l}(0.5022>0.0 \\
5)\end{array}$ & $\begin{array}{l}\text { Insignificant } \\
\text { effect. } \mathrm{HO} \\
\text { rejected }\end{array}$ \\
\hline (b) & EPS & 7.059722 & $\begin{array}{l}(0.0008<0.05 \\
)\end{array}$ & $\begin{array}{l}\text { Significan } \\
t \text { positive } \\
\text { effect. } H 1 \\
\text { accepted }\end{array}$ & EPS & 3.928813 & $\begin{array}{l}(0.5179>0.0 \\
5)\end{array}$ & $\begin{array}{l}\text { Insignificant } \\
\text { effect. } \mathrm{H} 1 \\
\text { rejected }\end{array}$ \\
\hline (c) & DPS & 61.00841 & $\begin{array}{l}(0.0000<0.05 \\
)\end{array}$ & $\begin{array}{l}\text { Significan } \\
t \text { positive } \\
\text { effect. } \mathrm{H} 2 \\
\text { accepted }\end{array}$ & DPS & 33.59069 & $\begin{array}{l}(0.2872>0.0 \\
5)\end{array}$ & $\begin{array}{l}\text { Insignificant } \\
\text { effect. } \mathrm{H} 2 \\
\text { rejected }\end{array}$ \\
\hline (d) & DPR & -7.331832 & $\begin{array}{l}(0.0013<0.05 \\
)\end{array}$ & $\begin{array}{l}\text { Significan } \\
t \text { negative } \\
\text { effect. H3 } \\
\text { accepted }\end{array}$ & DPR & -3.617106 & $\begin{array}{l}(0.0762>0.0 \\
5)\end{array}$ & $\begin{array}{l}\text { Insignificant } \\
\text { effect. } \mathrm{H} 3 \\
\text { rejected }\end{array}$ \\
\hline (e) & PER & 0.061568 & $\begin{array}{l}(0.0000<0.05 \\
)\end{array}$ & $\begin{array}{l}\text { Significan } \\
\text { t positive } \\
\text { effect. } \mathrm{H} 4 \\
\text { accepted }\end{array}$ & PER & 0.112454 & $\begin{array}{l}(0.0000<0.0 \\
5)\end{array}$ & $\begin{array}{l}\text { Significant } \\
\text { positive } \\
\text { partial } \\
\text { effect. H4 } \\
\text { accepted }\end{array}$ \\
\hline (f) & LASSET & 2.031314 & $\begin{array}{l}(0.0389<0.05 \\
)\end{array}$ & $\begin{array}{l}\text { Significan } \\
\text { t positive } \\
\text { effect. } \mathrm{H5} \\
\text { accepted }\end{array}$ & LASSET & -21.14702 & $\begin{array}{l}(0.4347>0.0 \\
5)\end{array}$ & $\begin{array}{l}\text { Insignificant } \\
\text { effect. } \mathrm{H} 5 \\
\text { rejected }\end{array}$ \\
\hline
\end{tabular}




\begin{tabular}{|c|c|c|c|c|c|c|c|c|}
\hline (g) & GDPGR & -1.596778 & $\begin{array}{l}(0.9004>0.05 \\
)\end{array}$ & $\begin{array}{l}\text { Insignific } \\
\text { ant effect. } \\
\text { H6 } \\
\text { rejected }\end{array}$ & GDPGR & -51.14591 & $\begin{array}{l}(0.9408>0.0 \\
5)\end{array}$ & $\begin{array}{l}\text { Insignificant } \\
\text { effect. H6 } \\
\text { rejected }\end{array}$ \\
\hline (h) & INFR & -27.03355 & $\begin{array}{l}(0.0869>0.05 \\
)\end{array}$ & $\begin{array}{l}\text { Insignific } \\
\text { ant effect. } \\
\mathrm{H} 7 \\
\text { rejected }\end{array}$ & INFR & 14.50280 & $\begin{array}{l}(0.6840>0.0 \\
5)\end{array}$ & $\begin{array}{l}\text { Insignificant } \\
\text { effect. } \mathrm{H} 7 \\
\text { rejected }\end{array}$ \\
\hline (i) & INTR & -15.50890 & $\begin{array}{l}(0.5421>0.05 \\
)\end{array}$ & $\begin{array}{l}\text { Insignific } \\
\text { ant effect. } \\
\text { H8 } \\
\text { rejected }\end{array}$ & INTR & 2468.204 & $\begin{array}{l}(0.1448>0.0 \\
5)\end{array}$ & $\begin{array}{l}\text { Insignificant } \\
\text { effect. } \mathrm{H} 8 \\
\text { rejected }\end{array}$ \\
\hline (j) & CT & 37.90745 & $\begin{array}{l}(0.3070>0.05 \\
)\end{array}$ & $\begin{array}{l}\text { Insignific } \\
\text { ant effect. } \\
\text { H9 } \\
\text { rejected }\end{array}$ & $\mathrm{CT}$ & -7053.961 & $\begin{array}{l}(0.0000<0.0 \\
5)\end{array}$ & $\begin{array}{l}\text { Significant } \\
\text { negative } \\
\text { effect. H9 } \\
\text { accepted }\end{array}$ \\
\hline (k) & EXCHR & -0.045328 & $\begin{array}{l}(0.2409>0.05 \\
)\end{array}$ & $\begin{array}{l}\text { Insignific } \\
\text { ant effect. } \\
\text { H10reject } \\
\text { ed }\end{array}$ & EXCHR & 743.9563 & $\begin{array}{l}(0.0010<0.0 \\
5)\end{array}$ & $\begin{array}{l}\text { Significant } \\
\text { positive } \\
\text { effect. } \\
\text { H10rejected }\end{array}$ \\
\hline
\end{tabular}

Table 6: Comparative Analysis of Regression Result between Emerging and Emerged Market

\section{Conclusion and Recommendations}

The main objective of this study was to investigate the effect of internal (microeconomic) and external (macroeconomic) factors on the market price of a share of pharmaceuticals companies of emerging market (India) and emerged market (the US and Europe). During the course of study, 200 observations for emerging market and 181 observations for emerged markets, were examined and analyzed to understand the diverse behaviour of the same variables in emerging and emerged markets. The statistical estimation method was based on panel OLS regression while considering the fixed effect model. This research strived to establish an association between the market price of the share (MPS) and other eleven variables for both emerging and emerged markets separately.

The empirical findings show a positive and significant relationship between EPS, DPS, PER, and LASSET with market price of the share (MPS) for emerging (India) market. This significant positive relation with MPS explains why higher EPS and DPS make companies more attractive for investment. Similarly, PER exerts the same impact on companies by making investors willing to buy their share at current market price even during the rally and thus fuel the overall upward growth. On the same note, higher LASSET growth boosts confidence in investors towards companies' growth and investment outlook. Having said that, significant negative relation of ROE and DPR with MPS show that higher return on equity causes decrement in share price because of possible approach of middle size companies in aggressive reinvestment of retained earnings and investors' money towards their expansion. Therefore, higher dividend payout ratio causes apprehension in investor's mind about investment and growth policy of companies and that affects MPS in a negative manner.

Since pharmaceutical companies are considered the non-cyclical industry, with better immunity against macroeconomic fluctuations, this study further reinforces that macroeconomic factors such as GDP growth, Inflation rate, interest rate and exchange rate do not affect significantly the market price of a share of pharmaceutical companies of the emerging market. In the case of emerged markets, most of the internal factors except PER do not show any significant effect on the MPS of US and European pharmaceutical companies. The possible reason behind this result could be the weak effect of ROE, EPS, DPS, and DPR on the MSP. As per data, these factors for many middle size pharmaceutical companies of the emerged market show that although they had negative EPS and they didn't pay DPS due to negative net income, MPS wasn't affected severely. Moreover, significant positive relationship between PER and MPS also brings to fore a crucial fact that despite successive bad results and unattractive dividend policies, investors showed their confidence in those companies. In emerged markets, the story is rather different. This study reveals macroeconomic factors such as GDP growth, Inflation rate and Interest rate, do not affect significantly the market price of a share of pharmaceutical companies of the emerged market. However, higher fluctuation in corporate tax and variation in exchange rates 
show a significant negative and positive effect respectively on the MPS of pharmaceutical companies of the emerged market. The probable reason behind it could be the close relationship between the European and US economy.

Possible recommendations promulgated by this study are stemmed firmly into the domains of micro and macroeconomics factors affecting key performance of pharmaceutical companies of emerging and emerged markets. During the research, pharmaceutical companies from five countries in the emerged market and one country in the emerging market have been considered to study the patterns of stock price changes. Along the same line, this methodology can also be implemented to study the pharmaceutical companies of each country separately, to achieve a more comprehensive and precise results, which can be helpful for investors and managers to understand and predict the stock patterns before investing their capital in pharmaceutical stocks. Also, the further studies can be helpful for the investors to comprehend the potentials of different countries in the field of pharmaceutical developments beforehand. In conclusion, it is worthwhile to mention that this study has paved the path to delve deeper into financial conditions of pharmaceutical companies of different countries from a novel perspective.

\section{Limitations}

Considering a few limitations of financial ratios, in some situations, financial ratios don't necessarily give very precise financial information such as distorted balance sheet of the firm due to inflation, different accounting policies in place and practices of different firms (https://www.thebalancesmb.com/limitations-offinancial-ratio-analysis-393236).

Since many middle and small-sized pharmaceutical companies in the USA and Europe are private entities and not listed in the stock exchange, only twenty companies have been taken from emerged markets in this study.

Huge difference in operational, financial, other parameters between big and small emerged companies may cause biased regression results.

This study gives a generalized idea about the effect of internal and external factors on the stock price of pharmaceutical companies in emerging and emerged market and how these factors behave differently in a different market.

This study doesn't give a complete picture of share price fluctuation in the pharmaceutical sector of the entire emerging and emerged markets.

In this study, in order to compare the regression results of pharmaceutical companies, in both emerging and emerged markets, fixed effect model has employed. Additionally, Hausman test has been performed and it was inferred that Random effect would have been more appropriate for Indian firms but considering the objective of this study, which is doing a comparative analysis of regression results of two different markets, the fixed effect was given chosen instead of random effect.

\section{References}

Akif, S. \& Noreen, U. (2016). Price Volatility and Role of Dividend Policy: Empirical Evidence from Pakistan. International Journal of Economics and Financial Issues, Vol. 6(No. 2), 461-472.

Akinsulire, O. (2014). Financial Management 8th ., Lagos: -Toda Ventures.

Alfred, D.D. (2007). . Corporate Finance: Issues, Investigations, Innovation \&nApplications, Lagos: High Rise Publications.

Asmirantho, E and Somantri, O. K. (2017). The Effect of Financial Performance on Stock Price at Pharmaceutical Subsector Company Listed in Indonesia Stock Exchange.

Jurnal Ilmiah Akuntansi Fakultas Ekonomi Vol. 3(No. 2), 94-107

Besley, S. \& Brigham, E.F. (2008). Essentials of Managerial Finance, Thomson South-Western.nhttps://epdf.tips/essentials-of-managerialfinance.html

Enrile, O.B. (2018). The Relationship Between Dividend Payout Ratio and the Share Prices of Companies Listed at the Nairobi Securities Exchange. , International Journal of Economics, Commerce and Management, Vol. 6(No.6), 615-642.

Ellis, J., \& Howell, D. (2018). Tax reform's influence on life sciences investments, Boston Business Journal.

Friedman, M. (1987). "Quantity Theory of Money" A Dictionary of Economics, vol. 4, 3-20. 
Githinji, G.G. (2011). Relationship between Price Earning Ratio and Share Prices of Companies Listed on the Nairobi Stock Exchange.

Ghaeli, M.R. (2017). Price-to-earnings ratio: A state-of-art review. Accounting 3, 131-136.

Haque, S. \& Faruquee, M. (2013). Impact of Fundamental Factors on Stock Price: A Case Based Approach on Pharmaceutical Companies Listed with Dhaka Stock Exchange. International Journal of Business and Management Invention, vol.2(No.9), 34 -41.

Hasan, M. et al., (2015). Dividend Payout Ratio and Firm's Profitability. Evidence from Pakistan. Theoretical Economics Letters, (No.5), $441-445$.

Hashemijoo, M., Ardekani, A.M. \& Younesi, N. (2012). The Impact of Dividend Policy on Share Price Volatility in the Malaysian Stock Market. Journal of Business Studies Quarterly, Vol. 4(No. 1), 111-129.

Hunjra, A.I. et al., (2014). Impact of Micro Economic Variables on Firms Performance. International Journal of Economics and Empirical Research, 65-73.

Islam, M.R. et al., (2014). How Earning Per Share (EPS) Affects on Share Price and Firm Value. European Journal of Business and Management, Vol. 6(No. 17), .97-108.'

Jhingan, M., (1997), Macroeconomic theory, Vrinda publishing, Delhi.

Jõeveer, K. (2013). Firm, Country and Macroeconomic Determinants of Capital Structure: Evidence from Transition Economics. Journal of Comparative Economics. Vol.41 (No.1), 294-308.

Herawati , A. \& Setiadiputra, A. (2018). The influence of Fundamental Analysis on Stock Prices: The Case of Food and Beverage Industries. European Research Studies Journal, Volume XXI (No. 3), 316-326.

Hirshleifer, D.A., Hsu, P. \& Li, D. (2013). Innovative efficiency and stock returns. Journal of Financial Economics, Vol. 107.

Is there a Correlation between GDP Growth and Stock Market Returns? https://www.wise-owl.com/investment-education/is-there-acorrelation-between-gdp-growth-and-stock-market-returns

Kamar, K. (2017). Analysis of the Effect of Return on Equity (ROE) and Debt to Equity Ratio (DER) On Stock Price on Cement Industry Listed In Indonesia Stock Exchange (Idx) In the Year of 2011-2015. IOSR Journal of Business and Management (IOSR-JBM), Vol.19(No.5), 66-76.

Kampamba, S. (2017). The Impact of GDP, Inflation, Interest and Exchange rates GDP on the Stock Market in Zambia, Working Paper, ECONOMICS ASSOCIATION OF ZAMBIA.

Kapoor, S. (2009). Impact of Dividend Policy on Shareholders' Value: A Study of Indian Firms, Synopsis. Jaypee Institute of Information Technology, Noida, 1-39.

Kijewska, A., (2016). Determinants of the Return on Equity Ratio (ROE) on the Example of Companies from Metallurgy and Mining Sector in Poland. Metalurgija, Vol.55(No.2), 285-288.

Kumar, P. (2017). , Impact of Earning per Share and Price Earnings Ratio on Market Price of Share: A Study on Auto Sector in India. International Journal of Research -GRANTHAALAYAH, Vol. 5(No. 2), 113-118.

Laurens, S. (2018). Influence Analysis of DPS, EPS, and PBV toward Stock Price and Return. The WINNERS, Vol. 19(No.1), 21-29.

Law, J. (2008). Is Pharma recession-proof? Pharmaceutical Technology Europe, 20(11). Available at: http://www.pharmtech.com/pharmarecession-proof- 0 .

Muhammad, N., \& Rasheed, A. (2002).Stock Prices and Exchange Rates: Are they Related? Evidence from South Asian Countries, The Pakistan Development Review Vol.41 (N0.4) Part II.

Nicholson, S.F. (1960). Price-earnings ratios. Financial Analysts Journal, Vol. 16(No. 4), pp. $43-45$.

O'riordan, A., Julian, K., Brückner, A., Bajaaj, A. (2016). Global pharmaceutical company: developing a more customer-centric commercial model to meet rapid market changes. Accenture Research.

Öztekin., Ö. (2015). Capital Structure Decisions Around the World: Which Factors are Reliably Important? Journal of Financial and Quantitative Analysis, Vol. 50 (No. 3), 301-323.

Paul, R. K., Multicollinearity:Causes, Effects and Remedies M. Sc. (Agricultural Statistics), Roll No. 4405I.A.S.R.I, Library Avenue, New Delhi-110012

Pound Sterling Live. https://www.poundsterlinglive.com.

Qaisi, F.A., Tahtamouni, A. \& AL-Qudah , M. (2016). Factors Affecting the Market Stock Price - The Case of the Insurance Companies Listed in Amman Stock Exchange. International Journal of Business and Social Science, Vol. 7(No. 10), 81-90.

Renata Perić, \& LjubicaKordić. (2014). The Role of Taxation during the Financial Crisis 2008-2013: Selected Issues. Review paper, UDK 336.26:338.124.4"2008/2013"

Roe, M. (2013). Did taxes cause the financial crisis? World Economic Forum, 22 AUG 2013

Trading Economics. https://tradingeconomics.com/ (Corporate tax rate and interest rate for all countries using this site)

Raju, M.B.H. \& Asaduzzaman, A.H.M. (2017). The Impact of Dividend Policy on Stock Price: A Study of Fuel, Power and Cement Industry in Bangladesh. Journal of Economics and Finance (IOSR-JEF), Vol. 8(No.03), 84-91.

Raymond, T.Y.C. (2002). Price-Earnings Ratios, Dividend Yields and Real Estate Stock Prices. Journal of Real Estate Portfolio Management, Vol. 8(No. 2), 107-113. 
Saragih, J.L. (2017). The Effects of Return on Assets (ROA), Return on Equity (ROE), and Debt to Equity Ratio (DER) on Stock Returns in the Wholesale and Retail Trade Companies Listed in Indonesia Stock Exchange. International Journal of Science and Research Methodology, Human Journals, Vol. 8 (No.3), 348-367.

Seddigi, H., \& Lawler, K. A. (2000). Econometrics: a practical approach. New York: Routledge

Sharma , S. (2011). Determinants of Equity Share Prices in India, Journal of Arts, science, and Commerce. Journal of Arts, science, and Commerce, Vol. 2(No.4), 51-60.

Sharif, T., Purohit, H. \& Pillai, R. (2015). Analysis of Factors Affecting Share Prices: The Case of Bahrain Stock Exchange. International Journal of Economics and Finance, Vol. 7(No. 3), 207-216.

Simon,S. P. (2009). Dividend Policy; T/Dialogue; www.hkiaat.org/images/uploads/articles/dividend.pdf.

Subramanian, V.A. \& Murugesu, T. (2013). Impact of Earning Per Share (EPS) On Share Price (Listed Manufacturing Companies in Sri Lanka). International Journal of Innovative Research \& Studies, Vol.2(No. 12), 251-258.

Sukmawati, F. \& Garsela, I. (2016). The Effect of Return on Assets and Return on Equity to the Stock Price. Advances in Economics, Business and Management Research, Vol. 15. 1st Global Conference on Business, Management and Entreupreuneurship (GCBME-16)

Suparnihgsih, B. (2017). Effect of debt to equity ratio (DER), price earnings ratio (PER), net profit margin (NPM), return on investment (ROI), earning per share (EPS) In influence exchange rates and Indonesian interest rates (SBI) share price in textile and garment industry Indonesia stock exchange. International Journal of Multidisciplinary Research and Development, Vol. 04(No. 11), 5862 .

Tamuntuan, U. (2015). The Effect of Return on Equity, Return on Assets and Earnings Per Share Toward Share Price: An Emperical Study of Food and Beverage Companies Listed on Indonesia Stock Exchange. JurnalBerkalaIlmiahEfisiensi, Vol. 1 (No.05).

Thorp, W.A. (2012). Deconstructing ROE: DuPont Analysis. Computerized Investing Articles. Available at: https://www.aaii.com/journal/article/deconstructing-roe-dupont-analysis.

Uddin, M., Rahman, S. \& Hossain, R. (2013). Determinants of Stock Prices in Financial Sector Companies in Bangladesh- A Study on Dhaka Stock Exchange (DSE). Interdisciplinary Journal of Contemporary Research in Business, Vol. 5(No. 3).

Watanabe, A. et al., (2012). The asset growth effect: Insights from international-equity markets. Journal of Financial Economics, Vol. 108(No. 2), 529-563.

What Are the Limitations of Ratio Analysis? https://www.thebalancesmb.com/limitations-of-financial-ratio-analysis-393236.

Wild, J.J. \& Subramanyam, K.R. (2008). Financial Statement Analysis 10th., McGraw-Hill/Irwin.

World Data Atlas. https://knoema.com/atlas (for all countries using this site)

Appendices:

Key Financial Data of Selected Companies:

\begin{tabular}{|c|c|c|c|c|c|}
\hline \multirow[t]{2}{*}{$\begin{array}{l}\text { Yea } \\
\mathbf{r}\end{array}$} & \multicolumn{5}{|c|}{$\begin{array}{c}\text { Firm Specific Data of Indian Pharmaceutical Companies } \\
\text { Annual Financial data in millions of US Dollars }\end{array}$} \\
\hline & $\begin{array}{l}\text { Sun } \\
\text { Pharmaceuticals } \\
\text { India }\end{array}$ & $\begin{array}{l}\text { Lupin Limited } \\
\text { India }\end{array}$ & $\begin{array}{l}\text { Cipla Limited } \\
\text { India }\end{array}$ & $\begin{array}{l}\text { Unichem } \\
\text { Laboratory Ltd. } \\
\text { India }\end{array}$ & $\begin{array}{l}\text { Cadila } \\
\text { Healthcare } \\
\text { India }\end{array}$ \\
\hline $\begin{array}{l}2007 \\
- \\
2008\end{array}$ & $\begin{array}{l}\text { MPS:2.82466233 } \\
1 \\
\text { ROE:38.30\% } \\
\text { EPS:0.186843422 } \\
\text { DPS:0.026263 } \\
\text { DPR:0.141 } \\
\text { PE_RATIO:15.1 } \\
\text { 18 } \\
\text { ASSET:1520.460 } \\
23\end{array}$ & $\begin{array}{l}\text { MPS:2.47073536 } \\
8 \\
\text { ROE: } 37.90 \% \\
\text { EPS: } \\
0.250125063 \\
\text { DPS:0.025013 } \\
\text { DPR:0.100 } \\
\text { PE_RATIO:9.87 } \\
8 \\
\text { ASSET:842.8464 } \\
232\end{array}$ & $\begin{array}{l}\text { MPS:5.49649824 } \\
9 \\
\text { ROE:20.10\% } \\
\text { EPS: } \\
0.225612806 \\
\text { DPS:0.050025 } \\
\text { DPR:0.222 } \\
\text { PE_RATIO:24.3 } \\
63 \\
\text { ASSET:1433.866 } \\
933\end{array}$ & $\begin{array}{l}\text { MPS:1.30115057 } \\
5 \\
\text { ROE:12.80\% } \\
\text { EPS:0.142571286 } \\
\text { DPS:0.050025 } \\
\text { DPR:0.351 } \\
\text { PE_RATIO:9.12 } \\
6 \\
\text { ASSET:151.5757 } \\
879\end{array}$ & $\begin{array}{l}\text { MPS:0.80165082 } \\
5 \\
\text { ROE:26.80\% } \\
\text { EPS:0.068284142 } \\
\text { DPS:0.015008 } \\
\text { DPR:0.220 } \\
\text { PE_RATIO:11.7 } \\
\text { 40 } \\
\text { ASSET:637.2686 } \\
343\end{array}$ \\
\hline $\begin{array}{l}2008 \\
- \\
2009\end{array}$ & $\begin{array}{l}\text { MPS:2.19600869 } \\
4 \\
\text { ROE:30.20\% } \\
\text { EPS:0.173483501 }\end{array}$ & $\begin{array}{l}\text { MPS:2.72357241 } \\
7 \\
\text { ROE:37.10\% } \\
\text { EPS:0.240466311 }\end{array}$ & $\begin{array}{l}\text { MPS:4.34202726 } \\
7 \\
\text { ROE: } 19.00 \% \\
\text { EPS:0.196008694 }\end{array}$ & $\begin{array}{l}\text { MPS: } 1.26812882 \\
8 \\
\text { ROE: } 24.10 \% \\
\text { EPS: }\end{array}$ & $\begin{array}{l}\text { MPS:0.71685437 } \\
7 \\
\text { ROE:25.70\% } \\
\text { EPS:0.058486465 }\end{array}$ \\
\hline
\end{tabular}




\begin{tabular}{|c|c|c|c|c|c|}
\hline & $\begin{array}{l}\text { DPS:0.027267 } \\
\text { DPR:0.157 } \\
\text { PE_RATIO:12.6 } \\
\text { 58 } \\
\text { ASSET:1632.780 } \\
083\end{array}$ & $\begin{array}{l}\text { DPS:0.049397 } \\
\text { DPR:0.205 } \\
\text { PE_RATIO:11.3 } \\
26 \\
\text { ASSET:793.7759 } \\
336\end{array}$ & $\begin{array}{l}\text { DPS:0.039518 } \\
\text { DPR:0.202 } \\
\text { PE_RATIO:22.1 } \\
52 \\
\text { ASSET:1316.301 } \\
126\end{array}$ & $\begin{array}{l}\text { 0.236909702 } \\
\text { DPS:0.063229 } \\
\text { DPR:0.267 } \\
\text { PE_RATIO:5.35 } \\
\text { 3 } \\
\text { ASSET:139.7945 } \\
07\end{array}$ & $\begin{array}{l}\text { DPS:0.011855 } \\
\text { DPR:0.203 } \\
\text { PE_RATIO:12.2 } \\
\text { 57 } \\
\text { ASSET:668.5437 } \\
661\end{array}$ \\
\hline $\begin{array}{l}2009 \\
- \\
2010\end{array}$ & $\begin{array}{l}\text { MPS:3.99776910 } \\
2 \\
\text { ROE:18.20\% } \\
\text { EPS:0.145454545 } \\
\text { DPS:0.030786 } \\
\text { DPR:0.212 } \\
\text { PE_RATIO:27.4 } \\
\text { 85 } \\
\text { ASSET:2023.892 } \\
917\end{array}$ & $\begin{array}{l}\text { MPS:7.24841048 } \\
5 \\
\text { ROE:34.10\% } \\
\text { EPS:0.353374233 } \\
\text { DPS:0.060234 } \\
\text { DPR:0.170 } \\
\text { PE_RATIO:20.5 } \\
12 \\
\text { ASSET:1134.523 } \\
146\end{array}$ & $\begin{array}{l}\text { MPS:7.52035694 } \\
4 \\
\text { ROE: } 21.10 \% \\
\text { EPS:0.305633017 } \\
\text { DPS:0.044618 } \\
\text { DPR:0.146 } \\
\text { PE_RATIO:24.6 } \\
\text { 06 } \\
\text { ASSET:1630.585 } \\
\text { 611 }\end{array}$ & $\begin{array}{l}\text { MPS:3.58148354 } \\
7 \\
\text { ROE:23.50\% } \\
\text { EPS: } \\
0.304740658 \\
\text { DPS:0.089236 } \\
\text { DPR:0.293 } \\
\text { PE_RATIO:11.7 } \\
\text { 53 } \\
\text { ASSET:179.1634 } \\
\text { 133 }\end{array}$ & $\begin{array}{l}\text { MPS:2.45398773 } \\
\text { ROE:35.30\% } \\
\text { EPS:0.111098717 } \\
\text { DPS:0.014947 } \\
\text { DPR:0.135 } \\
\text { PE_RATIO:22.0 } \\
88 \\
\text { ASSET:844.2833 } \\
24\end{array}$ \\
\hline $\begin{array}{l}2010 \\
- \\
2011\end{array}$ & $\begin{array}{l}\text { MPS:4.96911847 } \\
3 \\
\text { ROE:21.00\% } \\
\text { EPS:0.196967996 } \\
\text { DPS:0.039304 } \\
\text { DPR:0.200 } \\
\text { PE_RATIO:25.2 } \\
\text { 28 } \\
\text { ASSET:2778.910 } \\
724\end{array}$ & $\begin{array}{l}\text { MPS:9.32846715 } \\
3 \\
\text { ROE:29.50\% } \\
\text { EPS:0.434811903 } \\
\text { DPS:0.067378 } \\
\text { DPR:0.155 } \\
\text { PE_RATIO:21.4 } \\
\text { 54 } \\
\text { ASSET:1375.496 } \\
912\end{array}$ & $\begin{array}{l}\text { MPS:7.21055586 } \\
7 \\
\text { ROE:15.70\% } \\
\text { EPS:0.276698484 } \\
\text { DPS:0.062886 } \\
\text { DPR:0.227 } \\
\text { PE_RATIO:26.0 } \\
\text { 59 } \\
\text { ASSET:1930.758 } \\
\text { 001 }\end{array}$ & $\begin{array}{l}\text { MPS:4.25154407 } \\
6 \\
\text { ROE:16.10\% } \\
\text { EPS:0.23649635 } \\
\text { DPS:0.089837 } \\
\text { DPR:0.380 } \\
\text { PE_RATIO:17.9 } \\
77 \\
\text { ASSET:197.9337 } \\
451\end{array}$ & $\begin{array}{l}\text { MPS:3.55440763 } \\
6 \\
\text { ROE:37.40\% } \\
\text { EPS:0.156092083 } \\
\text { DPS:0.028074 } \\
\text { DPR:0.180 } \\
\text { PE_RATIO:22.7 } \\
71 \\
\text { ASSET:1035.508 } \\
\text { 141 }\end{array}$ \\
\hline $\begin{array}{l}2011 \\
- \\
2012\end{array}$ & $\begin{array}{l}\text { MPS:5.59277794 } \\
1 \\
\text { ROE:24.50\% } \\
\text { EPS:0.251790796 } \\
\text { DPS:0.041802 } \\
\text { DPR:0.166 } \\
\text { PE_RATIO:22.2 } \\
\text { 12- } \\
\text { ASSET:3233.048 } \\
769\end{array}$ & $\begin{array}{l}\text { MPS:10.3944657 } \\
1 \\
\text { ROE:23.80\% } \\
\text { EPS:0.381316848 } \\
\text { DPS:0.062801 } \\
\text { DPR:0.165 } \\
\text { PE_RATIO:27.2 } \\
\text { 59 } \\
\text { ASSET:1566.519 } \\
478\end{array}$ & $\begin{array}{l}\text { MPS:5.97684231 } \\
2 \\
\text { ROE:16.00\% } \\
\text { EPS:0.279658522 } \\
\text { DPS:0.03925 } \\
\text { DPR:0.140 } \\
\text { PE_RATIO:21.3 } \\
72 \\
\text { ASSET:1834.913 } \\
\text { 159 }\end{array}$ & $\begin{array}{l}\text { MPS:2.59248356 } \\
4 \\
\text { ROE: } 11.10 \% \\
\text { EPS:0.154842508 } \\
\text { DPS:0.058875 } \\
\text { DPR:0.380 } \\
\text { PE_RATIO:16.7 } \\
43 \\
\text { ASSET:193.6218 } \\
232\end{array}$ & $\begin{array}{l}\text { MPS:2.98341674 } \\
\text { ROE:27.40\% } \\
\text { EPS:0.125012266 } \\
\text { DPS:0.029438 } \\
\text { DPR:0.235 } \\
\text { PE_RATIO:23.8 } \\
65 \\
\text { ASSET:1260.523 } \\
992\end{array}$ \\
\hline $\begin{array}{l}2012 \\
- \\
2013\end{array}$ & $\begin{array}{l}\text { MPS:7.54315188 } \\
4 \\
\text { ROE:22.00\% } \\
\text { EPS:0.265266648 } \\
\text { DPS:0.046053 } \\
\text { DPR:0.174 } \\
\text { PE_RATIO:28.4 } \\
\text { 36 } \\
\text { ASSET:3791.599 } \\
889\end{array}$ & $\begin{array}{l}\text { MPS:11.5879156 } \\
3 \\
\text { ROE:28.50\% } \\
\text { EPS:0.541401861 } \\
\text { DPS:0.073685 } \\
\text { DPR:0.136 } \\
\text { PE_RATIO:21.4 } \\
\text { 04 } \\
\text { ASSET:1642.055 } \\
817\end{array}$ & $\begin{array}{l}\text { MPS:6.99548678 } \\
3 \\
\text { ROE:18.50\% } \\
\text { EPS: } \\
0.354425716 \\
\text { DPS:0.036843 } \\
\text { DPR:0.104 } \\
\text { PE_RATIO:19.7 } \\
\text { 38 } \\
\text { ASSET:2147.701 } \\
943\end{array}$ & $\begin{array}{l}\text { MPS:3.18412084 } \\
4 \\
\text { ROE:16.30\% } \\
\text { EPS: } \\
0.230634614 \\
\text { DPS:0.082896 } \\
\text { DPR:0.359 } \\
\text { PE_RATIO:13.8 } \\
\text { 06 } \\
\text { ASSET:197.5683 } \\
\text { 891 }\end{array}$ & $\begin{array}{l}\text { MPS:2.73132541 } \\
2 \\
\text { ROE:23.60\% } \\
\text { EPS:0.117527862 } \\
\text { DPS:0.027632 } \\
\text { DPR:0.235 } \\
\text { PE_RATIO:23.2 } \\
40 \\
\text { ASSET:1358.423 } \\
\text { 137 }\end{array}$ \\
\hline $\begin{array}{l}2013 \\
-\end{array}$ & $\begin{array}{l}\text { MPS:9.58555703 } \\
8 \\
\text { ROE:18.80\% }\end{array}$ & $\begin{array}{l}\text { MPS:15.6087391 } \\
6 \\
\text { ROE:30.30\% }\end{array}$ & $\begin{array}{l}\text { MPS:6.39926617 } \\
7 \\
\text { ROE:14.60\% }\end{array}$ & $\begin{array}{l}\text { MPS:3.82338225 } \\
5 \\
\text { ROE:16.60\% }\end{array}$ & $\begin{array}{l}\text { MPS:3.42361574 } \\
4 \\
\text { ROE:25.20\% }\end{array}$ \\
\hline
\end{tabular}




\begin{tabular}{|c|c|c|c|c|c|}
\hline 2014 & $\begin{array}{l}\text { EPS:0.253002001 } \\
\text { DPS:0.025017 } \\
\text { DPR:0.099 } \\
\text { PE_RATIO:37.8 } \\
\text { 87 } \\
\text { ASSET:4898.398 } \\
933\end{array}$ & $\begin{array}{l}\text { EPS:0.683622415 } \\
\text { DPS:0.100067 } \\
\text { DPR:0.146 } \\
\text { PE_RATIO:22.8 } \\
\text { 32 } \\
\text { ASSET:1702.134 } \\
75\end{array}$ & $\begin{array}{l}\text { EPS:0.288358906 } \\
\text { DPS:0.033356 } \\
\text { DPR:0.116 } \\
\text { PE_RATIO:22.1 } \\
92 \\
\text { ASSET:2235.356 } \\
\text { 905 }\end{array}$ & $\begin{array}{l}\text { EPS:0.311707805 } \\
\text { DPS:0.133422 } \\
\text { DPR:0.428 } \\
\text { PE_RATIO:12.2 } \\
66 \\
\text { ASSET:190.9106 } \\
071\end{array}$ & $\begin{array}{l}\text { EPS:0.130920614 } \\
\text { DPS:0.03002 } \\
0.229 \\
\text { DPR:0.229 } \\
\text { PE_RATIO:26.1 } \\
\text { 50 } \\
\text { ASSET:1331.971 } \\
\text { 314 }\end{array}$ \\
\hline $\begin{array}{l}2014 \\
- \\
2015\end{array}$ & $\begin{array}{l}\text { MPS:16.4007688 } \\
6 \\
\text { ROE:19.50\% } \\
\text { EPS:0.302418709 } \\
\text { DPS:0.048054 } \\
\text { DPR:0.159 } \\
\text { PE_RATIO:54.2 } \\
\text { 32 } \\
\text { ASSET:8034.614 } \\
769\end{array}$ & $\begin{array}{l}\text { MPS:32.1488066 } \\
6 \\
\text { ROE:29.80\% } \\
\text { EPS:0.856158898 } \\
\text { DPS:0.120135 } \\
\text { DPR:0.140 } \\
\text { PE_RATIO:37.5 } \\
\text { 50 } \\
\text { ASSET:2124.139 } \\
03\end{array}$ & $\begin{array}{l}\text { MPS:11.3919589 } \\
9 \\
\text { ROE:11.40\% } \\
\text { EPS: } \\
0.235623899 \\
\text { DPS:0.032036 } \\
\text { DPR:0.136 } \\
\text { PE_RATIO:48.3 } \\
48 \\
\text { ASSET:2506.343 } \\
\text { 104 }\end{array}$ & $\begin{array}{l}\text { MPS:3.26125260 } \\
3 \\
\text { ROE:8.80\% } \\
\text { EPS: } \\
0.133109082 \\
\text { DPS:0.032036 } \\
\text { DPR:0.241 } \\
\text { PE_RATIO:24.5 } \\
01 \\
\text { ASSET:187.1856 } \\
479\end{array}$ & $\begin{array}{l}\text { MPS:5.57200064 } \\
1 \\
\text { ROE:28.90\% } \\
\text { EPS:0.180041647 } \\
\text { DPS:0.038443 } \\
\text { DPR:0.214 } \\
\text { PE_RATIO:30.9 } \\
48 \\
\text { ASSET:1463.110 } \\
684\end{array}$ \\
\hline $\begin{array}{l}2015 \\
- \\
2016\end{array}$ & $\begin{array}{l}\text { MPS:4.22609614 } \\
4 \\
\text { ROE:14.90\% } \\
\text { EPS:0.29582673 } \\
\text { DPS:0.015093 } \\
\text { DPR:0.051 } \\
\text { PE_RATIO:14.2 } \\
86 \\
\text { ASSET:8381.299 } \\
525\end{array}$ & $\begin{array}{l}\text { MPS:21.8889140 } \\
4 \\
\text { ROE:22.20\% } \\
\text { EPS:0.761451966 } \\
\text { DPS:0.113199 } \\
\text { DPR:0.149 } \\
\text { PE_RATIO:28.7 } \\
46 \\
\text { ASSET:3414.821 } \\
523\end{array}$ & $\begin{array}{l}\text { MPS:7.73073730 } \\
3 \\
\text { ROE:12.30\% } \\
\text { EPS:0.255527885 } \\
\text { DPS:0.030186 } \\
\text { DPR:0.118 } \\
\text { PE_RATIO:30.2 } \\
54 \\
\text { ASSET:3188.921 } \\
\text { 591 }\end{array}$ & $\begin{array}{l}\text { MPS:3.34993585 } \\
4 \\
\text { ROE:11.70\% } \\
\text { EPS: } \\
0.179609086 \\
\text { DPS:0.030186 } \\
\text { DPR:0.168 } \\
\text { PE_RATIO:18.6 } \\
51 \\
\text { ASSET:193.7514 } \\
15\end{array}$ & $\begin{array}{l}\text { MPS:4.78378990 } \\
3 \\
\text { ROE:37.80\% } \\
\text { EPS:0.224435892 } \\
\text { DPS:0.048298 } \\
\text { DPR:0.215 } \\
\text { PE_RATIO:21.3 } \\
\text { 15 } \\
\text { ASSET:1592.423 } \\
213\end{array}$ \\
\hline $\begin{array}{l}2016 \\
- \\
2017\end{array}$ & $\begin{array}{l}\text { MPS:10.6097749 } \\
\text { ROE:20.00\% } \\
\text { EPS:0.446808511 } \\
\text { DPS:0.053962 } \\
\text { DPR:0.121 } \\
\text { PE_RATIO:23.7 } \\
46 \\
\text { ASSET:9468.115 } \\
942\end{array}$ & $\begin{array}{l}\text { MPS:22.2756706 } \\
8 \\
\text { ROE:20.70\% } \\
\text { EPS:0.874036386 } \\
\text { DPS:0.115634 } \\
\text { DPR:0.132 } \\
\text { PE_RATIO:25.4 } \\
86 \\
\text { ASSET:4102.266 } \\
42\end{array}$ & $\begin{array}{l}\text { MPS:9.13197656 } \\
5 \\
\text { ROE:8.40\% } \\
\text { EPS:0.193031144 } \\
\text { DPS:0.030836 } \\
\text { DPR:0.160 } \\
\text { PE_RATIO:47.3 } \\
\text { 08 } \\
\text { ASSET:3243.462 } \\
843\end{array}$ & $\begin{array}{l}\text { MPS:4.41335183 } \\
5 \\
\text { ROE:-7.00\% } \\
\text { EPS:0.184397163 } \\
\text { DPS:0.046253 } \\
\text { DPR:0.251 } \\
\text { PE_RATIO:23.9 } \\
34 \\
\text { ASSET:235.3684 } \\
86\end{array}$ & $\begin{array}{l}\text { MPS:6.83395004 } \\
6 \\
\text { ROE:23.50\% } \\
\text { EPS:0.224020968 } \\
\text { DPS:0.049337 } \\
\text { DPR:0.220 } \\
\text { PE_RATIO:30.5 } \\
06 \\
\text { ASSET:2346.700 } \\
\text { 586 }\end{array}$ \\
\hline
\end{tabular}

\begin{tabular}{|c|c|c|c|c|c|}
\hline \multirow[t]{2}{*}{$\begin{array}{l}\text { Yea } \\
\mathbf{r}\end{array}$} & \multicolumn{5}{|c|}{$\begin{array}{c}\text { Firm Specific Data of Indian Pharmaceutical Companies } \\
\text { Annual Financial data in millions of US Dollars }\end{array}$} \\
\hline & $\begin{array}{l}\text { Glenmark } \\
\text { Pharmaceuticals } \\
\text { Ltd India }\end{array}$ & $\begin{array}{l}\text { TTK Healthcare } \\
\text { India }\end{array}$ & $\begin{array}{l}\text { IPCA Laborator } \\
\text { ies India }\end{array}$ & $\begin{array}{l}\text { Torrent } \\
\text { Pharmaceuticals } \\
\text { India }\end{array}$ & $\begin{array}{l}\text { Biocon } \\
\text { India }\end{array}$ \\
\hline $\begin{array}{l}2007 \\
- \\
2008\end{array}$ & $\begin{array}{l}\text { MPS:12.2736368 } \\
2 \\
\text { ROE57.40\%: } \\
\text { EPS:0.646323162 } \\
\text { DPS:0.017509 } \\
\text { DPR:0.027 } \\
\text { PE RATIO:18.9 }\end{array}$ & $\begin{array}{l}\text { MPS:1.77588794 } \\
4 \\
\text { ROE:23.10\% } \\
\text { EPS:0.375937969 } \\
\text { DPS:0.075038 } \\
\text { DPR:0.200 } \\
\text { PE RATIO:4.72 }\end{array}$ & $\begin{array}{l}\text { MPS:3.04502251 } \\
1 \\
\text { ROE:25.50\% } \\
\text { EPS:0.271635818 } \\
\text { DPS:0.04002 } \\
\text { DPR:0.147 } \\
\text { PE RATIO:11.2 }\end{array}$ & $\begin{array}{l}\text { MPS: } 1.76838419 \\
2 \\
\text { ROE:29.30\% } \\
\text { EPS:0.19909955 } \\
\text { DPS:0.043772 } \\
\text { DPR:0.220 } \\
\text { PE RATIO:8.88 }\end{array}$ & $\begin{array}{l}\text { MPS:1.79514757 } \\
4 \\
\text { ROE:37.20\% } \\
\text { EPS:0.20010005 } \\
\text { DPS:0.012506 } \\
\text { DPR:0.062 } \\
\text { PE RATIO:8.97 }\end{array}$ \\
\hline
\end{tabular}




\begin{tabular}{|c|c|c|c|c|c|}
\hline & $\begin{array}{l}90 \\
\text { ASSET:736.7683 } \\
842\end{array}$ & $\begin{array}{l}4 \\
\text { ASSET:30.46773 } \\
387\end{array}$ & $\begin{array}{l}10 \\
\text { ASSET:290.6203 } \\
102\end{array}$ & $\begin{array}{l}2 \\
\text { ASSET:318.6843 } \\
422\end{array}$ & $\begin{array}{l}1 \\
\text { ASSET:519.9849 } \\
925\end{array}$ \\
\hline $\begin{array}{l}2008 \\
- \\
2009\end{array}$ & $\begin{array}{l}\text { MPS:3.11796087 } \\
7 \\
\text { ROE:12.30\% } \\
\text { EPS:0.151551077 } \\
\text { DPS:0.007904 } \\
\text { DPR:0.052 } \\
\text { PE_RATIO:20.5 } \\
74 \\
\text { ASSET:841.2369 } \\
\text { 097 }\end{array}$ & $\begin{array}{l}\text { MPS:1.88203912 } \\
3 \\
\text { ROE:13.18\% } \\
\text { EPS:0.191859316 } \\
\text { DPS:0.059277 } \\
\text { DPR:0.309 } \\
\text { PE_RATIO:9.80 } \\
9 \\
\text { ASSET:27.64671 } \\
\text { 014 }\end{array}$ & $\begin{array}{l}\text { MPS:1.29994072 } \\
3 \\
\text { ROE:16.50\% } \\
\text { EPS:0.158664296 } \\
\text { DPS:0.04347 } \\
\text { DPR:0.274 } \\
\text { PE_RATIO:8.19 } \\
\text { 3 } \\
\text { ASSET:271.6064 } \\
\text { 019 }\end{array}$ & $\begin{array}{l}\text { MPS:1.32444181 } \\
\text { ROE:31.80\% } \\
\text { EPS:0.215372456 } \\
\text { DPS:0.039518 } \\
\text { DPR:0.183 } \\
\text { PE_RATIO:6.15 } \\
\text { 0 } \\
\text { ASSET:329.4803 } \\
399\end{array}$ & $\begin{array}{l}\text { MPS: } \\
\text { 0.951788184 } \\
\text { ROE:6.21\% } \\
\text { EPS:0.031811895 } \\
\text { DPS:0.019759 } \\
\text { DPR:0.621 } \\
\text { PE_RATIO:29.9 } \\
\text { 19 } \\
\text { ASSET:502.5884 } \\
213\end{array}$ \\
\hline $\begin{array}{l}2009 \\
- \\
2010\end{array}$ & $\begin{array}{l}\text { MPS:5.93976575 } \\
6 \\
\text { ROE:16.40\% } \\
\text { EPS:0.277523703 } \\
\text { DPS:0.008924 } \\
\text { DPR:0.032 } \\
\text { PE_RATIO:21.4 } \\
\text { 03 } \\
\text { ASSET:1089.525 } \\
\text { 934 }\end{array}$ & $\begin{array}{l}\text { MPS:5.71890686 } \\
\text { ROE:14.40\% } \\
\text { EPS:0.260568879 } \\
\text { DPS:0.078081 } \\
\text { DPR:0.300 } \\
\text { PE_RATIO:21.9 } \\
48 \\
\text { ASSET:34.60122 } \\
699\end{array}$ & $\begin{array}{l}\text { MPS:6.01896263 } \\
2 \\
\text { ROE:27.50\% } \\
\text { EPS:0.366759621 } \\
\text { DPS:0.062465 } \\
\text { DPR:0.170 } \\
\text { PE_RATIO:16.4 } \\
11 \\
\text { ASSET:360.7808 } \\
143\end{array}$ & $\begin{array}{l}\text { MPS:6.08075850 } \\
5 \\
\text { ROE:31.20\% } \\
\text { EPS:0.304740658 } \\
\text { DPS:0.066927 } \\
\text { DPR:0.220 } \\
\text { PE_RATIO:19.9 } \\
\text { 54 } \\
\text { ASSET:438.4160 } \\
625\end{array}$ & $\begin{array}{l}\text { MPS:2.11444506 } \\
4 \\
\text { ROE:17.90\% } \\
\text { EPS:0.112214166 } \\
\text { DPS:0.026102 } \\
\text { DPR:0.233 } \\
\text { PE_RATIO:18.8 } \\
43 \\
\text { ASSET:655.0139 } \\
431\end{array}$ \\
\hline $\begin{array}{l}2010 \\
- \\
2011\end{array}$ & $\begin{array}{l}\text { MPS:6.36945536 } \\
2 \\
\text { ROE:20.60\% } \\
\text { EPS:0.376866929 } \\
\text { DPS:0.008984 } \\
\text { DPR:0.024 } \\
\text { PE_RATIO:16.9 } \\
\text { 01 } \\
\text { ASSET:1144.929 } \\
\text { 815 }\end{array}$ & $\begin{array}{l}\text { MPS:9.07018528 } \\
9 \\
\text { ROE:20.96\% } \\
\text { EPS:0.425828186 } \\
\text { DPS:0.089837 } \\
\text { DPR:0.211 } \\
\text { PE_RATIO:21.3 } \\
\text { 00 } \\
\text { ASSET:43.32172 } \\
937\end{array}$ & $\begin{array}{l}\text { MPS:6.77372262 } \\
8 \\
\text { ROE:27.40\% } \\
\text { EPS:0.470746771 } \\
\text { DPS:0.07187 } \\
\text { DPR:0.153 } \\
\text { PE_RATIO:14.3 } \\
89 \\
\text { ASSET:429.3767 } \\
\text { 546 }\end{array}$ & $\begin{array}{l}\text { MPS:6.49477821 } \\
4 \\
\text { ROE:29.20\% } \\
\text { EPS:0.358674902 } \\
\text { DPS:0.067378 } \\
\text { DPR:0.188 } \\
\text { PE_RATIO:18.1 } \\
\text { 08 } \\
\text { ASSET:572.5772 } \\
\text { 038 }\end{array}$ & $\begin{array}{l}\text { MPS:2.57495788 } \\
9 \\
\text { ROE:19.39\% } \\
\text { EPS:0.140595171 } \\
\text { DPS:0.033689 } \\
\text { DPR:0.240 } \\
\text { PE_RATIO:18.3 } \\
\text { 15 } \\
\text { ASSET:805.3003 } \\
93\end{array}$ \\
\hline $\begin{array}{l}2011 \\
- \\
2012\end{array}$ & $\begin{array}{l}\text { MPS:6.03768030 } \\
6 \\
\text { ROE:10.70\% } \\
\text { EPS:0.334216466 } \\
\text { DPS:0.03925 } \\
\text { DPR:0.117 } \\
\text { PE_RATIO:18.0 } \\
\text { 65 } \\
\text { ASSET:1154.626 } \\
631\end{array}$ & $\begin{array}{l}\text { MPS:7.67049357 } \\
3 \\
\text { ROE:19.13\% } \\
\text { EPS:0.39505446 } \\
\text { DPS:0.078501 } \\
\text { DPR:0.199 } \\
\text { PE_RATIO:19.4 } \\
\text { 16- } \\
\text { ASSET:37.75488 } \\
\text { 176 }\end{array}$ & $\begin{array}{l}\text { MPS:6.57442841 } \\
7 \\
\text { ROE:24.00\% } \\
\text { EPS:0.431361005 } \\
\text { DPS:0.062801 } \\
\text { DPR:0.146 } \\
\text { PE_RATIO:15.2 } \\
\text { 41 } \\
\text { ASSET:456.7363 } \\
36\end{array}$ & $\begin{array}{l}\text { MPS:6.16858012 } \\
\text { ROE:25.60\% } \\
\text { EPS:0.329310176 } \\
\text { DPS:0.083407 } \\
\text { DPR:0.253 } \\
\text { PE_RATIO:18.7 } \\
\text { 32 } \\
\text { ASSET:600.4710 } \\
038\end{array}$ & $\begin{array}{l}\text { MPS:1.55725640 } \\
3 \\
\text { ROE:15.70\% } \\
\text { EPS:0.113040918 } \\
\text { DPS:0.032774 } \\
\text { DPR:0.290 } \\
\text { PE_RATIO:13.7 } \\
76 \\
\text { ASSET:774.2125 } \\
\text { 405 }\end{array}$ \\
\hline $\begin{array}{l}2012 \\
- \\
2013\end{array}$ & $\begin{array}{l}\text { MPS:8.52077001 } \\
\text { ROE:24.00\% } \\
\text { EPS:0.422031869 } \\
\text { DPS:0.036843 } \\
\text { DPR:0.087 } \\
\text { PE_RATIO:20.1 } \\
\text { 90 } \\
\text { ASSET:1320.991 } \\
066\end{array}$ & $\begin{array}{l}\text { MPS:7.44496638 } \\
1 \\
\text { ROE:15.30\% } \\
\text { EPS:0.336925486 } \\
\text { DPS:0.073685 } \\
\text { DPR:0.219 } \\
\text { PE_RATIO:22.0 } \\
97 \\
\text { ASSET:38.56498 } \\
112\end{array}$ & $\begin{array}{l}\text { MPS:9.70065395 } \\
6 \\
\text { ROE:23.00\% } \\
\text { EPS:0.472506217 } \\
\text { DPS:0.073685 } \\
\text { DPR:0.156 } \\
\text { PE_RATIO:20.5 } \\
\text { 30 } \\
\text { ASSET:496.8223 } \\
\text { 266 }\end{array}$ & $\begin{array}{l}\text { MPS:6.40361057 } \\
4 \\
\text { ROE:33.10\% } \\
\text { EPS:0.471032514 } \\
\text { DPS:0.119738 } \\
\text { DPR:0.254 } \\
\text { PE_RATIO:13.5 } \\
\text { 95 } \\
\text { ASSET:697.0433 } \\
821\end{array}$ & $\begin{array}{l}\text { MPS:1.68610113 } \\
3 \\
\text { ROE:20.50\% } \\
\text { EPS:0.159528415 } \\
\text { DPS: } 0.030764 \\
\text { DPR:0.193 } \\
\text { PE_RATIO:10.5 } \\
\text { 69 } \\
\text { ASSET:813.5028 } \\
092\end{array}$ \\
\hline
\end{tabular}




\begin{tabular}{|c|c|c|c|c|c|}
\hline $\begin{array}{l}2013 \\
- \\
2014\end{array}$ & $\begin{array}{l}\text { MPS:9.43795863 } \\
9 \\
\text { ROE:18.90\% } \\
\text { EPS:0.333722482 } \\
\text { DPS:0.033356 } \\
\text { DPR:0.100 } \\
\text { PE_RATIO:28.2 } \\
81 \\
\text { ASSET:1439.893 } \\
262\end{array}$ & $\begin{array}{l}\text { MPS:8.73082054 } \\
7 \\
\text { ROE:12.60\% } \\
\text { EPS:0.266010674 } \\
\text { DPS:0.066711 } \\
\text { DPR:0.251 } \\
\text { PE_RATIO:32.8 } \\
21 \\
\text { ASSET:40.01667 } \\
779\end{array}$ & $\begin{array}{l}\text { MPS:14.0893929 } \\
3 \\
\text { ROE:27.20\% } \\
\text { EPS:0.632421614 } \\
\text { DPS:0.083389 } \\
\text { DPR:0.132 } \\
\text { PE_RATIO:22.2 } \\
78 \\
\text { ASSET:535.4069 } \\
38\end{array}$ & $\begin{array}{l}\text { MPS:8.73332221 } \\
5 \\
\text { ROE:39.90\% } \\
\text { EPS:0.654269513 } \\
\text { DPS:0.166778 } \\
\text { DPR:0.255 } \\
\text { PE_RATIO:13.3 } \\
\text { 48 } \\
\text { ASSET:845.5303 } \\
536\end{array}$ & $\begin{array}{l}\text { MPS:2.35740493 } \\
7 \\
\text { ROE:14.50\% } \\
\text { EPS:0.11724483 } \\
\text { DPS:0.027852 } \\
\text { DPR:0.238 } \\
\text { PE_RATIO:20.1 } \\
\text { 07 } \\
\text { ASSET:959.0727 } \\
\text { 151 }\end{array}$ \\
\hline $\begin{array}{l}2014 \\
- \\
2015\end{array}$ & $\begin{array}{l}\text { MPS:12.5901009 } \\
1 \\
\text { ROE:15.90\% } \\
\text { EPS:0.28063431 } \\
\text { DPS:0.032036 } \\
\text { DPR:0.114 } \\
\text { PE_RATIO:44.8 } \\
\text { 63 } \\
\text { ASSET:1551.737 } \\
947\end{array}$ & $\begin{array}{l}\text { MPS:14.8966842 } \\
9 \\
\text { ROE:14.35\% } \\
\text { EPS:0.333173154 } \\
\text { DPS:0.072081 } \\
\text { DPR:0.216 } \\
\text { PE_RATIO:44.7 } \\
12 \\
\text { ASSET:44.08137 } \\
114\end{array}$ & $\begin{array}{l}\text { MPS:10.2282556 } \\
5 \\
\text { ROE:12.20\% } \\
\text { EPS:0.322761493 } \\
\text { DPS:0.016018 } \\
\text { DPR:0.050 } \\
\text { PE_RATIO:31.6 } \\
\text { 90 } \\
\text { ASSET:660.7079 } \\
93\end{array}$ & $\begin{array}{l}\text { MPS:18.3429441 } \\
\text { ROE:33.00\% } \\
\text { EPS:0.710876181 } \\
\text { DPS:0.180202 } \\
\text { DPR:0.253 } \\
\text { PE_RATIO:25.8 } \\
03 \\
\text { ASSET:1275.684 } \\
767\end{array}$ & $\begin{array}{l}\text { MPS:2.50680762 } \\
5 \\
\text { ROE:15.80\% } \\
\text { EPS:0.132788723 } \\
\text { DPS:0.02675 } \\
\text { DPR:0.201 } \\
\text { PE_RATIO:18.8 } \\
78 \\
\text { ASSET:1014.239 } \\
949\end{array}$ \\
\hline $\begin{array}{l}2015 \\
- \\
2016\end{array}$ & $\begin{array}{l}\text { MPS:11.9885291 } \\
7 \\
\text { ROE:19.30\% } \\
\text { EPS:0.377480945 } \\
\text { DPS:0.030186 } \\
\text { DPR:0.080 } \\
\text { PE_RATIO:31.7 } \\
\text { 59 } \\
\text { ASSET:1635.499 } \\
\text { 208 }\end{array}$ & $\begin{array}{l}\text { MPS:13.9612104 } \\
7 \\
\text { ROE:17.46\% } \\
\text { EPS:0.440570523 } \\
\text { DPS:0.075466 } \\
\text { DPR:0.171 } \\
\text { PE_RATIO:31.6 } \\
89 \\
\text { ASSET:45.25092 } \\
446\end{array}$ & $\begin{array}{l}\text { MPS:8.75028299 } \\
8 \\
\text { ROE:4.20\% } \\
\text { EPS:0.11138782 } \\
\text { DPS:0 } \\
\text { DPR:0.000 } \\
\text { PE_RATIO:78.5 } \\
57 \\
\text { ASSET:587.3820 } \\
844\end{array}$ & $\begin{array}{l}\text { MPS:20.2203607 } \\
3 \\
\text { ROE:56.50\% } \\
\text { EPS:1.545845597 } \\
\text { DPS:0.301864 } \\
\text { DPR:0.195 } \\
\text { PE_RATIO:13.0 } \\
\text { 80 } \\
\text { ASSET:1367.127 } \\
\text { 009 }\end{array}$ & $\begin{array}{l}\text { MPS:2.42547732 } \\
2 \\
\text { ROE:15.10\% } \\
\text { EPS:0.140366765 } \\
\text { DPS:0.025206 } \\
\text { DPR:0.180 } \\
\text { PE_RATIO:17.2 } \\
80 \\
\text { ASSET:1276.597 } \\
993\end{array}$ \\
\hline $\begin{array}{l}2016 \\
- \\
2017\end{array}$ & $\begin{array}{l}\text { MPS:13.2246376 } \\
8 \\
\text { ROE:19.90\% } \\
\text { EPS:0.500462535 } \\
\text { DPS:0.030836 } \\
\text { DPR:0.062 } \\
\text { PE_RATIO:26.4 } \\
25 \\
\text { ASSET:1882.824 } \\
545\end{array}$ & $\begin{array}{l}\text { MPS:12.2224791 } \\
9 \\
\text { ROE:12.52\% } \\
\text { EPS:0.372032069 } \\
\text { DPS:0.077089 } \\
\text { DPR:0.207 } \\
\text { PE_RATIO:32.8 } \\
\text { 53 } \\
\text { ASSET:43.92537 } \\
774\end{array}$ & $\begin{array}{l}\text { MPS:9.61069996 } \\
9 \\
\text { ROE:8.30\% } \\
\text { EPS:0.237742831 } \\
\text { DPS:0.015418 } \\
\text { DPR:0.065 } \\
\text { PE_RATIO:40.4 } \\
25 \\
\text { ASSET:610.4687 } \\
018\end{array}$ & $\begin{array}{l}\text { MPS:23.8860622 } \\
9 \\
\text { ROE:23.80\% } \\
\text { EPS:0.850601295 } \\
\text { DPS:0.21585 } \\
\text { DPR:0.254 } \\
\text { PE_RATIO:28.0 } \\
81 \\
\text { ASSET:1495.713 } \\
845\end{array}$ & $\begin{array}{l}\text { MPS:5.82531606 } \\
5 \\
\text { ROE:13.80\% } \\
\text { EPS:0.160191181 } \\
\text { DPS:0.015418 } \\
\text { DPR:0.096 } \\
\text { PE_RATIO:36.3 } \\
65 \\
\text { ASSET:1448.381 } \\
\text { 129 }\end{array}$ \\
\hline
\end{tabular}

\begin{tabular}{|c|c|c|c|c|c|}
\hline \multirow[t]{2}{*}{$\begin{array}{l}\text { Yea } \\
\mathbf{r}\end{array}$} & \multicolumn{5}{|c|}{$\begin{array}{c}\text { Firm Specific Data of Indian Pharmaceutical Companies } \\
\text { Annual Financial data in millions of US Dollars }\end{array}$} \\
\hline & FDC Ltd. India & Dabur India & $\begin{array}{l}\text { Ajanta } \\
\text { Pharmaceutical } \\
\text { s } \\
\text { India }\end{array}$ & $\begin{array}{l}\text { NATCO } \\
\text { Pharmaceutical } \\
\text { s } \\
\text { India }\end{array}$ & $\begin{array}{l}\text { JB Chem. And } \\
\text { Pharmaceuticals } \\
\text { India }\end{array}$ \\
\hline $\begin{array}{l}200 \\
7- \\
200 \\
8\end{array}$ & $\begin{array}{l}\text { MPS:0.7141070 } \\
54 \\
\text { ROE: } 17.90 \% \\
\text { EPS:0.08254127 } \\
1 \\
\text { DPS:0.025013 }\end{array}$ & $\begin{array}{l}\text { MPS:0.8741870 } \\
94 \\
\text { ROE:60.86\% } \\
\text { EPS:0.04827413 } \\
7 \\
\text { DPS:0.018759 }\end{array}$ & $\begin{array}{l}\text { MPS:0.2668834 } \\
42 \\
\text { ROE:17.50\% } \\
\text { EPS:0.06228114 } \\
1 \\
\text { DPS:0.008254 }\end{array}$ & $\begin{array}{l}\text { MPS:0.4239619 } \\
81 \\
\text { ROE:28.30\% } \\
\text { EPS:0.07228614 } \\
3 \\
\text { DPS:0.006253 }\end{array}$ & $\begin{array}{l}\text { MPS:0.862931466 } \\
\text { ROE:10.40\% } \\
\text { EPS:0.134317159 } \\
\text { DPS:0.012506 } \\
\text { DPR:0.093 } \\
\text { PE_RATIO:6.425 }\end{array}$ \\
\hline
\end{tabular}




\begin{tabular}{|c|c|c|c|c|c|}
\hline & $\begin{array}{l}\text { DPR:0.303 } \\
\text { PE_RATIO:8.6 } \\
\text { 52_ } \\
\text { ASSET:125.537 } \\
7689\end{array}$ & $\begin{array}{l}\text { DPR:0.389 } \\
\text { PE_RATIO:18. } \\
\text { 109 } \\
\text { ASSET:370.385 } \\
1926\end{array}$ & $\begin{array}{l}\text { DPR:0.133 } \\
\text { PE_RATIO:4.2 } \\
85 \\
\text { ASSET:90.0200 } \\
1001\end{array}$ & $\begin{array}{l}\text { DPR:0.087 } \\
\text { PE_RATIO:5.8 } \\
65 \\
\text { ASSET:104.902 } \\
4512\end{array}$ & ASSET:185.4177089 \\
\hline $\begin{array}{l}200 \\
8- \\
200 \\
9\end{array}$ & $\begin{array}{l}\text { MPS:0.6757557 } \\
79 \\
\text { ROE:21.60\% } \\
\text { EPS:0.08931041 } \\
3 \\
\text { DPS:0.024699 } \\
\text { DPR:0.277 } \\
\text { PE_RATIO:7.5 } \\
\text { 66 } \\
\text { ASSET:108.911 } \\
\text { 2824 }\end{array}$ & $\begin{array}{l}\text { MPS:0.9751037 } \\
34 \\
\text { ROE:54.50\% } \\
\text { EPS:0.04465520 } \\
6 \\
\text { DPS:0.017388 } \\
\text { DPR:0.389 } \\
\text { PE_RATIO:21. } \\
836 \\
\text { ASSET:373.266 } \\
\text { 1529 }\end{array}$ & $\begin{array}{l}\text { MPS:0.1353487 } \\
45 \\
\text { ROE:17.40\% } \\
\text { EPS:0.05730092 } \\
9 \\
\text { DPS:0.00652 } \\
\text { DPR:0.114 } \\
\text { PE_RATIO:2.3 } \\
62 \\
\text { ASSET:90.7330 } \\
5671\end{array}$ & $\begin{array}{l}\text { MPS:0.1906737 } \\
8 \\
\text { ROE:24.13\% } \\
\text { EPS:0.06204307 } \\
4 \\
\text { DPS:0.00494 } \\
\text { DPR:0.080 } \\
\text { PE_RATIO:3.0 } \\
73 \\
\text { ASSET:103.932 } \\
\text { 0292 }\end{array}$ & $\begin{array}{l}\text { MPS:0.502074689 } \\
\text { ROE:5.60\% } \\
\text { EPS:0.06026477 } \\
\text { DPS:0.019759 } \\
\text { DPR:0.328 } \\
\text { PE_RATIO:8.331 } \\
\text { ASSET:148.844102 }\end{array}$ \\
\hline $\begin{array}{l}200 \\
9- \\
201 \\
0\end{array}$ & $\begin{array}{l}\text { MPS: } 1.7958728 \\
39 \\
\text { ROE:31.40\% } \\
\text { EPS:0.17824874 } \\
5 \\
\text { DPS:0.039041 } \\
\text { DPR:0.219 } \\
\text { PE_RATIO:10. } \\
\text { 075 } \\
\text { ASSET:152.258 } \\
7842\end{array}$ & $\begin{array}{l}\text { MPS: } 1.7691020 \\
64 \\
\text { ROE:47.60\% } \\
\text { EPS:0.06313441 } \\
2 \\
\text { DPS:0.022309 } \\
\text { DPR:0.353 } \\
\text { PE_RATIO:28. } \\
\text { 021 } \\
\text { ASSET:506.190 } \\
7418\end{array}$ & $\begin{array}{l}\text { MPS:0.5414389 } \\
29 \\
\text { ROE:19.90\% } \\
\text { EPS:0.08633575 } \\
\text { DPS:0.010485 } \\
\text { DPR:0.121 } \\
\text { PE_RATIO:6.2 } \\
71 \\
\text { ASSET:110.451 } \\
7568\end{array}$ & $\begin{array}{l}\text { MPS:0.5983268 } \\
27 \\
\text { ROE:17.81\% } \\
\text { EPS:0.07718906 } \\
9 \\
\text { DPS:0.008924 } \\
\text { DPR:0.116 } \\
\text { PE_RATIO:7.7 } \\
\text { 51 } \\
\text { ASSET:123.658 } \\
6726\end{array}$ & $\begin{array}{l}\text { MPS:1.09180145 } \\
\text { ROE:22.90\% } \\
\text { EPS:0.314110429 } \\
\text { DPS:0.044618 } \\
\text { DPR:0.142 } \\
\text { PE_RATIO:3.476 } \\
\text { ASSET:187.8192973 }\end{array}$ \\
\hline $\begin{array}{l}201 \\
0- \\
201 \\
1\end{array}$ & $\begin{array}{l}\text { MPS:2.2841100 } \\
51 \\
\text { ROE:26.40\% } \\
\text { EPS:0.18214486 } \\
2 \\
\text { DPS:0.044919 } \\
\text { DPR:0.247 } \\
\text { PE_RATIO:12. } \\
540 \\
\text { ASSET:172.869 } \\
\text { 1746 }\end{array}$ & $\begin{array}{l}\text { MPS:2.1572150 } \\
48 \\
\text { ROE:43.20\% } \\
\text { EPS:0.07344188 } \\
7 \\
\text { DPS:0.025828 } \\
\text { DPR:0.352 } \\
\text { PE_RATIO:29. } \\
373 \\
\text { ASSET:881.055 } \\
\text { 5867 }\end{array}$ & $\begin{array}{l}\text { MPS:0.5998877 } \\
04 \\
\text { ROE:24.50\% } \\
\text { EPS:0.12981471 } \\
1 \\
\text { DPS:0.015048 } \\
\text { DPR:0.116 } \\
\text { PE_RATIO:4.6 } \\
21 \\
\text { ASSET:117.282 } \\
\text { 4256 }\end{array}$ & $\begin{array}{l}\text { MPS:1.2282987 } \\
09 \\
\text { ROE:16.25\% } \\
\text { EPS:0.08534531 } \\
2 \\
\text { DPS:0.008984 } \\
\text { DPR:0.105 } \\
\text { PE_RATIO:14. } \\
\text { 392 } \\
\text { ASSET:158.854 } \\
\text { 5761 }\end{array}$ & $\begin{array}{l}\text { MPS:2.061987647 } \\
\text { ROE:22.10\% } \\
\text { EPS:0.370578327 } \\
\text { DPS:0.044919 } \\
\text { DPR:0.121 } \\
\text { PE_RATIO:5.564 } \\
\text { ASSET:224.4581696 }\end{array}$ \\
\hline $\begin{array}{l}201 \\
1- \\
201 \\
2\end{array}$ & $\begin{array}{l}\text { MPS: } 1.5356687 \\
27 \\
\text { ROE:20.40\% } \\
\text { EPS:0.14326366 } \\
4 \\
\text { DPS:0.03925 } \\
\text { DPR:0.274 } \\
\text { PE_RATIO:10. } \\
719 \\
\text { ASSET:169.325 } \\
8758\end{array}$ & $\begin{array}{l}\text { MPS:2.0881169 } \\
66 \\
\text { ROE:41.50\% } \\
\text { EPS:0.07261309 } \\
\text { DPS:0.025513 } \\
\text { DPR:0.351 } \\
\text { PE_RATIO:28. } \\
757 \\
\text { ASSET:824.315 } \\
\text { 5726 }\end{array}$ & $\begin{array}{l}\text { MPS:1.1936021 } \\
98 \\
\text { ROE:29.30\% } \\
\text { EPS:0.17270140 } \\
3 \\
\text { DPS:0.019625 } \\
\text { DPR:0.114 } \\
\text { PE_RATIO:6.9 } \\
11 \\
\text { ASSET:127.328 } \\
\text { 0345 }\end{array}$ & $\begin{array}{l}\text { MPS: } 1.3884800 \\
31 \\
\text { ROE: } 14.43 \% \\
\text { EPS:0.08065940 } \\
5 \\
\text { DPS:0.011775 } \\
\text { DPR:0.146 } \\
\text { PE_RATIO:17. } \\
214 \\
\text { ASSET:177.646 } \\
\text { 9434 }\end{array}$ & $\begin{array}{l}\text { MPS:1.157688156 } \\
\text { ROE:81.60\% } \\
\text { EPS:1.572171524 } \\
\text { DPS:0.03925 } \\
\text { DPR:0.025 } \\
\text { PE_RATIO:0.736 } \\
\text { ASSET:235.0701599 }\end{array}$ \\
\hline $\begin{array}{l}201 \\
2- \\
201 \\
3\end{array}$ & $\begin{array}{l}\text { MPS:1.6975223 } \\
36 \\
\text { ROE:21.00\% } \\
\text { EPS:0.15676522 } \\
1\end{array}$ & $\begin{array}{l}\text { MPS:2.5246384 } \\
82 \\
\text { ROE:40.00\% } \\
\text { EPS:0.08068527 } \\
2 \\
\end{array}$ & $\begin{array}{l}\text { MPS:3.1605415 } \\
86 \\
\text { ROE:32.40\% } \\
\text { EPS:0.23505572 } \\
4\end{array}$ & $\begin{array}{l}\text { MPS:1.5807313 } \\
25 \\
\text { ROE:14.27\% } \\
\text { EPS:0.08473795 } \\
7\end{array}$ & $\begin{array}{l}\text { MPS:1.308096159 } \\
\text { ROE:8.00\% } \\
\text { EPS:0.172791747 } \\
\text { DPS:0.055264 } \\
\text { DPR:0.320 } \\
\end{array}$ \\
\hline
\end{tabular}




\begin{tabular}{|c|c|c|c|c|c|}
\hline & $\begin{array}{l}\text { DPS:0.041448 } \\
\text { DPR:0.264 } \\
\text { PE_RATIO:10. } \\
\text { 828 } \\
\text { ASSET:178.004 } \\
9737\end{array}$ & $\begin{array}{l}\text { DPS:0.027632 } \\
\text { DPR:0.342 } \\
\text { PE_RATIO:31. } \\
290 \\
\text { ASSET:867.366 } \\
6759\end{array}$ & $\begin{array}{l}\text { DPS:0.115133 } \\
\text { DPR:0.490 } \\
\text { PE_RATIO:13. } \\
446 \\
\text { ASSET:132.301 } \\
7408\end{array}$ & $\begin{array}{l}\text { DPS:0.014737 } \\
\text { DPR:0.174 } \\
\text { PE_RATIO:18. } \\
\text { 654 } \\
\text { ASSET:199.023 } \\
6714\end{array}$ & $\begin{array}{l}\text { PE_RATIO:7.570 } \\
\text { ASSET:239.5136778 }\end{array}$ \\
\hline $\begin{array}{l}201 \\
3- \\
201 \\
4\end{array}$ & $\begin{array}{l}\text { MPS:2.1005670 } \\
45 \\
\text { ROE:16.60\% } \\
\text { EPS:0.12658439 } \\
\text { DPS:0.037525 } \\
\text { DPR:0.296 } \\
\text { PE_RATIO:16. } \\
\text { 594 } \\
\text { ASSET:176.651 } \\
\text { 1007 }\end{array}$ & $\begin{array}{l}\text { MPS:2.9944963 } \\
31 \\
\text { ROE:38.51\% } \\
\text { EPS:0.08739159 } \\
4 \\
\text { DPS:0.029186 } \\
\text { DPR:0.334 } \\
\text { PE_RATIO:34. } \\
265 \\
\text { ASSET:885.923 } \\
9493\end{array}$ & $\begin{array}{l}\text { MPS:6.6819546 } \\
36 \\
\text { ROE:47.40\% } \\
\text { EPS:0.44396264 } \\
2 \\
\text { DPS:0.066711 } \\
\text { DPR:0.150 } \\
\text { PE_RATIO:15. } \\
\text { 051 } \\
\text { ASSET:158.338 } \\
\text { 8926 }\end{array}$ & $\begin{array}{l}\text { MPS:2.6584389 } \\
59 \\
\text { ROE:16.30\% } \\
\text { EPS:0.10723815 } \\
9 \\
\text { DPS:0.016678 } \\
\text { DPR:0.156 } \\
\text { PE_RATIO:24. } \\
790 \\
\text { ASSET:199.416 } \\
2775\end{array}$ & $\begin{array}{l}\text { MPS:2.066711141 } \\
\text { ROE:6.00\%EPS:0.121 } \\
\text { 08072 } \\
\text { DPS:0.050033 } \\
\text { DPR:0.413 } \\
\text { PE_RATIO:17.069 } \\
\text { ASSET:225.3168779 }\end{array}$ \\
\hline $\begin{array}{l}201 \\
4- \\
201 \\
5\end{array}$ & $\begin{array}{l}\text { MPS:2.4291206 } \\
15 \\
\text { ROE:16.00\% } \\
\text { EPS:0.13342944 } \\
1 \\
\text { DPS:0.03604 } \\
\text { DPR:0.270 } \\
\text { PE_RATIO:18. } \\
205 \\
\text { ASSET:187.746 } \\
2758\end{array}$ & $\begin{array}{l}\text { MPS:4.2519621 } \\
98 \\
\text { ROE:35.70\% } \\
\text { EPS:0.09738907 } \\
6 \\
\text { DPS:0.032036 } \\
\text { DPR:0.329 } \\
\text { PE_RATIO:43. } \\
660 \\
\text { ASSET:950.584 } \\
6548\end{array}$ & $\begin{array}{l}\text { MPS:19.629184 } \\
69 \\
\text { ROE:41.40\% } \\
\text { EPS:0.56447220 } \\
9 \\
\text { DPS:0.096108 } \\
\text { DPR:0.170 } \\
\text { PE_RATIO:34. } \\
774 \\
\text { ASSET:183.149 } \\
\text { 127 }\end{array}$ & $\begin{array}{l}\text { MPS:6.7597308 } \\
99 \\
\text { ROE:17.14\% } \\
\text { EPS:0.13022585 } \\
3 \\
\text { DPS:0.016018 } \\
\text { DPR:0.123 } \\
\text { PE_RATIO51.9 } \\
\text { 08: } \\
\text { ASSET:221.399 } \\
968\end{array}$ & $\begin{array}{l}\text { MPS:3.094666026 } \\
\text { ROE:8.90\% } \\
\text { EPS:0.189652411 } \\
\text { DPS:0.064072 } \\
\text { DPR:0.338 } \\
\text { PE_RATIO:16.318 } \\
\text { ASSET:249.463399 }\end{array}$ \\
\hline $\begin{array}{l}201 \\
5- \\
201 \\
6\end{array}$ & $\begin{array}{l}\text { MPS:2.7960153 } \\
95 \\
\text { ROE:16.10\% } \\
\text { EPS:0.14308354 } \\
1 \\
\text { DPS:0.03396 } \\
\text { DPR:0.237 } \\
\text { PE_RATIO:19. } \\
\text { 541 } \\
\text { ASSET:191.049 } \\
7321\end{array}$ & $\begin{array}{l}\text { MPS:3.7604709 } \\
08 \\
\text { ROE:33.40\% } \\
\text { EPS:0.10746358 } \\
8 \\
\text { DPS:0.03396 } \\
\text { DPR:0.316 } \\
\text { PE_RATIO:34. } \\
\text { 993 } \\
\text { ASSET:1046.30 } \\
\text { 5939 }\end{array}$ & $\begin{array}{l}\text { MPS:21.288959 } \\
32 \\
\text { ROE:39.70\% } \\
\text { EPS:0.71285186 } \\
\text { DPS:0.120746 } \\
\text { DPR:0.169 } \\
\text { PE_RATIO:29. } \\
\text { 864 } \\
\text { ASSET:224.586 } \\
\text { 8236 }\end{array}$ & $\begin{array}{l}\text { MPS:6.2191532 } \\
71 \\
\text { ROE:14.67\% } \\
\text { EPS:0.13734812 } \\
5 \\
\text { DPS:0.018867 } \\
\text { DPR:0.137 } \\
\text { PE_RATIO:45. } \\
280 \\
\text { ASSET:274.952 } \\
8337\end{array}$ & $\begin{array}{l}\text { MPS:3.764244208 } \\
\text { ROE:13.50\% } \\
\text { EPS: } 0.288129198 \\
\text { DPS: } 0.075466 \\
\text { DPR: } 0.262 \\
\text { PE_RATIO: } 13.064 \\
\text { ASSET: } 248.6906649\end{array}$ \\
\hline $\begin{array}{l}201 \\
6- \\
201 \\
7\end{array}$ & $\begin{array}{l}\text { MPS:3.1467776 } \\
75 \\
\text { ROE:16.00\% } \\
\text { EPS:0.16342892 } \\
4 \\
\text { DPS:0.0346 } \\
\text { DPR:0.212 } \\
\text { PE_RATIO:19. } \\
255 \\
\text { ASSET:226.318 } \\
2239\end{array}$ & $\begin{array}{l}\text { MPS:4.2730496 } \\
45 \\
\text { ROE:28.30\% } \\
\text { EPS:0.11177921 } \\
7 \\
\text { DPS:0.03469 } \\
\text { DPR:0.310 } \\
\text { PE_RATIO:38. } \\
228 \\
\text { ASSET:1191.95 } \\
\text { 1896 }\end{array}$ & $\begin{array}{l}\text { MPS:27.139993 } \\
83 \\
\text { ROE:36.70\% } \\
\text { EPS:0.88791242 } \\
7 \\
\text { DPS:0.200432 } \\
\text { DPR:0.226 } \\
\text { PE_RATIO:30. } \\
\text { 566 } \\
\text { ASSET:284.875 } \\
\text { 1156 }\end{array}$ & $\begin{array}{l}\text { MPS:13.058896 } \\
08 \\
\text { ROE:33.00 } \\
\text { EPS:0.43000308 } \\
4 \\
\text { DPS:0.1040 } \\
\text { DPR:0.242 } \\
\text { PE_RATIO:30. } \\
\text { 369 } \\
\text { ASSET:357.323 } \\
\text { 4659 }\end{array}$ & $\begin{array}{l}\text { MPS: } 5.349984582 \\
\text { ROE: } 14.50 \% \\
\text { EPS: } 0.334566759 \\
\text { DPS: } 0.015418 \\
\text { DPR: } 0.046 \\
\text { PE_RATIO: } 15.991 \\
\text { ASSET: } 258.0943571\end{array}$ \\
\hline
\end{tabular}




\begin{tabular}{|c|c|c|c|c|c|}
\hline \multirow[t]{2}{*}{$\begin{array}{l}\text { Yea } \\
\text { r }\end{array}$} & \multicolumn{5}{|c|}{$\begin{array}{c}\text { Firm Specific Data of Indian Pharmaceutical Companies } \\
\text { Annual Financial data in millions of US Dollars }\end{array}$} \\
\hline & $\begin{array}{l}\text { Nectar Life } \\
\text { Sciences India }\end{array}$ & $\begin{array}{l}\text { Indoco Remedies } \\
\text { India }\end{array}$ & $\begin{array}{l}\text { RPG Life } \\
\text { Sciences India }\end{array}$ & $\begin{array}{l}\text { Albert David } \\
\text { India }\end{array}$ & $\begin{array}{l}\text { Aarti Drugs } \\
\text { India }\end{array}$ \\
\hline $\begin{array}{l}2007 \\
- \\
2008\end{array}$ & $\begin{array}{l}\text { MPS:0.50150075 } \\
\text { ROE:29.60\% } \\
\text { EPS:0.124312156 } \\
\text { DPS:0.010005 } \\
\text { DPR:0.080 } \\
\text { PE_RATIO:4.03 } \\
4 \\
\text { ASSET:237.2436 } \\
218\end{array}$ & $\begin{array}{l}\text { MPS:0.95722861 } \\
4 \\
\text { ROE:11.84\% } \\
\text { EPS:0.081790895 } \\
\text { DPS:0.016758 } \\
\text { DPR:0.205 } \\
\text { PE_RATIO:11.7 } \\
\text { 03 } \\
\text { ASSET:87.16858 } \\
429\end{array}$ & $\begin{array}{l}\text { MPS:0.83791895 } \\
9 \\
\text { ROE:12.09\% } \\
\text { EPS:0.104802401 } \\
\text { DPS:0.030015 } \\
\text { DPR:0.286 } \\
\text { PE_RATIO:7.99 } \\
5 \\
\text { ASSET:43.87693 } \\
847\end{array}$ & $\begin{array}{l}\text { MPS:1.89594797 } \\
4 \\
\text { ROE:15.04\% } \\
\text { EPS:0.32166083 } \\
\text { DPS:0.075038 } \\
\text { DPR:0.233 } \\
\text { PE_RATIO:5.89 } \\
4 \\
\text { ASSET:37.42871 } \\
436\end{array}$ & $\begin{array}{l}\text { MPS:0.65607803 } \\
9 \\
\text { ROE:13.10\% } \\
\text { EPS:0.146823412 } \\
\text { DPS:0.022511 } \\
\text { DPR:0.153 } \\
\text { PE_RATIO:4.46 } \\
8 \\
\text { ASSET:104.2021 } \\
\text { 011 }\end{array}$ \\
\hline $\begin{array}{l}2008 \\
- \\
2009\end{array}$ & $\begin{array}{l}\text { MPS:0.22228808 } \\
\text { 5 } \\
\text { ROE:18.00\% } \\
\text { EPS:0.068563525 } \\
\text { DPS:0.001976 } \\
\text { DPR:0.029 } \\
\text { PE_RATIO:3.24 } \\
2 \\
\text { ASSET:254.0209 } \\
445\end{array}$ & $\begin{array}{l}\text { MPS:0.36139102 } \\
9 \\
\text { ROE:11.80\% } \\
\text { EPS:0.06737798 } \\
\text { DPS:0.013831 } \\
\text { DPR:0.205 } \\
\text { PE_RATIO:5.36 } \\
4 \\
\text { ASSET:73.99723 } \\
\text { 375 }\end{array}$ & $\begin{array}{l}\text { MPS:0.45544358 } \\
8 \\
\text { ROE:12.70\% } \\
\text { EPS:0.090891128 } \\
\text { DPS:0.023711 } \\
\text { DPR0.261 } \\
\text { PE_RATIO:5.01 } \\
1 \\
\text { ASSET:33.18118 } \\
949\end{array}$ & $\begin{array}{l}\text { MPS:0.92076664 } \\
7 \\
\text { ROE:14.15\% } \\
\text { EPS:0.260620431 } \\
\text { DPS:0.069156 } \\
\text { DPR:0.265 } \\
\text { PE_RATIO:3.53 } \\
\text { 3 } \\
\text { ASSET:31.88697 } \\
886\end{array}$ & $\begin{array}{l}\text { MPS:0.37541987 } \\
7 \\
\text { ROE:13.70\% } \\
\text { EPS:0.134755977 } \\
\text { DPS:0.029638 } \\
\text { DPR:0.220 } \\
\text { PE_RATIO:2.78 } \\
6 \\
\text { ASSET:79.66804 } \\
979\end{array}$ \\
\hline $\begin{array}{l}2009 \\
- \\
2010\end{array}$ & $\begin{array}{l}\text { MPS:0.80758505 } \\
3 \\
\text { ROE:20.00\% } \\
\text { EPS:0.128276631 } \\
\text { DPS:0.005577 } \\
\text { DPR:0.043 } \\
\text { PE_RATIO:6.29 } \\
\text { 6 } \\
\text { ASSET:330.2844 } \\
\text { 395 }\end{array}$ & $\begin{array}{l}\text { MPS:1.18817624 } \\
1 \\
\text { ROE:14.30\% } \\
\text { EPS:0.101952036 } \\
\text { DPS:0.020747 } \\
\text { DPR:0.203 } \\
\text { PE_RATIO:11.6 } \\
54 \\
\text { ASSET:107.1500 } \\
279\end{array}$ & $\begin{array}{l}\text { MPS:1.63301728 } \\
9 \\
\text { ROE:18.10\% } \\
\text { EPS:0.167540435 } \\
\text { DPS:0.032125 } \\
\text { DPR:0.192 } \\
\text { PE_RATIO:9.74 } \\
7 \\
\text { ASSET:37.49023 } \\
982\end{array}$ & $\begin{array}{l}\text { MPS:2.66034578 } \\
9 \\
\text { ROE:17.28\% } \\
\text { EPS:0.401561629 } \\
\text { DPS:0.10039 } \\
\text { DPR:0.250 } \\
\text { PE_RATIO:6.62 } \\
\text { 5 } \\
\text { ASSET:41.26938 } \\
09\end{array}$ & $\begin{array}{l}\text { MPS1.139542666 } \\
: \\
\text { ROE:20.90\% } \\
\text { EPS:0.266369214 } \\
\text { DPS:0.055772 } \\
\text { DPR:0.209 } \\
\text { PE_RATIO:4.27 } \\
8 \\
\text { ASSET:93.49693 } \\
252\end{array}$ \\
\hline $\begin{array}{l}2010 \\
- \\
2011\end{array}$ & $\begin{array}{l}\text { MPS:0.53677709 } \\
2 \\
\text { ROE:15.50\% } \\
\text { EPS:0.10443571 } \\
\text { DPS:0.002246 } \\
\text { DPR:0.022 } \\
\text { PE_RATIO:5.14 } \\
\text { 0 } \\
\text { ASSET:407.0971 } \\
\text { 364 }\end{array}$ & $\begin{array}{l}\text { MPS:1.33295901 } \\
2 \\
\text { ROE:15.50\% } \\
\text { EPS:0.124649074 } \\
\text { DPS:0.024031 } \\
\text { DPR:0.193 } \\
\text { PE_RATIO:10.6 } \\
\text { 94- } \\
\text { ASSET:126.4907 } \\
\text { 355 }\end{array}$ & $\begin{array}{l}\text { MPS:1.70353733 } \\
9 \\
\text { ROE:18.30\% } \\
\text { EPS:0.180572712 } \\
\text { DPS:0.035935 } \\
\text { DPR:0.199 } \\
\text { PE_RATIO:9.43 } \\
4 \\
\text { ASSET:42.52891 } \\
63\end{array}$ & $\begin{array}{l}\text { MPS:2.61875350 } \\
9 \\
\text { ROE:16.19\% } \\
\text { EPS:0.426726558 } \\
\text { DPS:0.101067 } \\
\text { DPR:0.237 } \\
\text { PE_RATIO:6.13 } \\
7 \\
\text { ASSET:44.24031 } \\
443\end{array}$ & $\begin{array}{l}\text { MPS: } 1.43739472 \\
2 \\
\text { ROE:14.80\% } \\
\text { EPS:0.208422235 } \\
\text { DPS:0.056148 } \\
\text { DPR:0.269 } \\
\text { PE_RATIO:6.89 } \\
7 \\
\text { ASSET: } 115.8674 \\
90\end{array}$ \\
\hline $\begin{array}{l}2011 \\
- \\
2012\end{array}$ & $\begin{array}{l}\text { MPS:0.47198508 } \\
5 \\
\text { ROE:9.70\% } \\
\text { EPS:0.06397802 } \\
\text { DPS:0.001963 } \\
\text { DPR:0.031 } \\
\text { PE_RATIO:7.37 } \\
7 \\
\text { ASSET:416.2300 }\end{array}$ & $\begin{array}{l}\text { MPS:1.06172112 } \\
6 \\
\text { ROE:12.60\% } \\
\text { EPS:0.098714552 } \\
\text { DPS:0.021588 } \\
\text { DPR:0.219 } \\
\text { PE_RATIO:10.7 } \\
\text { 55 } \\
\text { ASSET:128.8195 } \\
\text { 467 }\end{array}$ & $\begin{array}{l}\text { MPS: } 1.25404768 \\
9 \\
\text { ROE:1.10\% } \\
\text { EPS:0.010008831 } \\
\text { DPS:0.0157 } \\
\text { DPR1.569 } \\
\text { PE_RATIO:125. } \\
294 \\
\text { ASSET:35.82180 }\end{array}$ & $\begin{array}{l}\text { MPS:1.63870081 } \\
4 \\
\text { ROE:10.42\% } \\
\text { EPS:0.262388382 } \\
\text { DPS:0.088313 } \\
\text { DPR:0.337 } \\
\text { PE_RATIO:6.24 } \\
\text { 5 } \\
\text { ASSET:39.80571 } \\
\text { 092 }\end{array}$ & $\begin{array}{l}\text { MPS:0.99931311 } \\
9 \\
\text { ROE:13.50\% } \\
\text { EPS:0.181925228 } \\
\text { DPS:0.049063 } \\
\text { DPR:0.270 } \\
\text { PE_RATIO:5.49 } \\
3 \\
\text { ASSET:120.2237 }\end{array}$ \\
\hline
\end{tabular}




\begin{tabular}{|c|c|c|c|c|c|}
\hline & 069 & & 355 & & 268 \\
\hline $\begin{array}{l}2012 \\
- \\
2013\end{array}$ & $\begin{array}{l}\text { MPS:0.28829326 } \\
7 \\
\text { ROE:10.40\% } \\
\text { EPS:0.070369347 } \\
\text { DPS:0.001842 } \\
\text { DPR:0.026 } \\
\text { PE_RATIO:4.09 } \\
7 \\
\text { ASSET:418.9002 } \\
\text { 487 }\end{array}$ & $\begin{array}{l}\text { MPS:1.06567191 } \\
7 \\
\text { ROE:10.70\% } \\
\text { EPS:0.085474809 } \\
\text { DPS:0.020263 } \\
\text { DPR:0.237 } \\
\text { PE_RATIO:12.4 } \\
\text { 68 } \\
\text { ASSET:127.4569 } \\
\text { 402 }\end{array}$ & $\begin{array}{l}\text { MPS:1.14212029 } \\
1 \\
\text { ROE:5.90\% } \\
\text { EPS:0.049184858 } \\
\text { DPS:0.022106 } \\
\text { DPR:0.449 } \\
\text { PE_RATIO:23.2 } \\
21 \\
\text { ASSET:37.90365 } \\
663\end{array}$ & $\begin{array}{l}\text { MPS:1.66067974 } \\
6 \\
\text { ROE:10.93\% } \\
\text { EPS:0.276319425 } \\
\text { DPS:0.082896 } \\
\text { DPR:0.300 } \\
\text { PE_RATIO:6.01 } \\
\text { 0 } \\
\text { ASSET:38.60919 } \\
223\end{array}$ & $\begin{array}{l}\text { MPS:1.31933314 } \\
9 \\
\text { ROE:23.54\% } \\
\text { EPS:0.344109791 } \\
\text { DPS:0.092106 } \\
\text { DPR:0.268 } \\
\text { PE_RATIO:3.83 } \\
4 \\
\text { ASSET:132.5780 } \\
60\end{array}$ \\
\hline $\begin{array}{l}2013 \\
- \\
2014\end{array}$ & $\begin{array}{l}\text { MPS:0.40360240 } \\
2 \\
\text { ROE:6.90\% } \\
\text { EPS:0.046197465 } \\
\text { DPS:0.001668 } \\
\text { DPR:0.036 } \\
\text { PE_RATIO:8.73 } \\
6 \\
\text { ASSET:399.2828 } \\
552\end{array}$ & $\begin{array}{l}\text { MPS:2.35573715 } \\
8 \\
\text { ROE:13.30\% } \\
\text { EPS:0.104903269 } \\
\text { DPS:0.023349 } \\
\text { DPR:0.223 } \\
\text { PE_RATIO:22.4 } \\
\text { 56 } \\
\text { ASSET:121.6477 } \\
652\end{array}$ & $\begin{array}{l}\text { MPS:1.00233489 } \\
\text { ROE:52.90\% } \\
\text { EPS:0.538525684 } \\
\text { DPS:0.020013 } \\
\text { DPR:0.037 } \\
\text { PE_RATIO:1.86 } \\
1 \\
\text { ASSET:32.70013 } \\
342\end{array}$ & $\begin{array}{l}\text { MPS:1.93462308 } \\
2 \\
\text { ROE:14.66\% } \\
\text { EPS:0.367411608 } \\
\text { DPS:0.083389 } \\
\text { DPR:0.227 } \\
\text { PE_RATIO:5.26 } \\
6 \\
\text { ASSET:33.02201 } \\
468\end{array}$ & $\begin{array}{l}\text { MPS:2.19646431 } \\
\text { ROE:26.90\% } \\
\text { EPS:0.424949967 } \\
\text { DPS:0.10840 } \\
\text { DPR:0.255 } \\
\text { PE_RATIO:5.16 } \\
9 \\
\text { ASSET:141.7111 } \\
40\end{array}$ \\
\hline $\begin{array}{l}2014 \\
- \\
2015\end{array}$ & $\begin{array}{l}\text { MPS:0.59106198 } \\
9 \\
\text { ROE:7.20\% } \\
\text { EPS:0.047252923 } \\
\text { DPS:0.001602 } \\
\text { DPR:0.034 } \\
\text { PE_RATIO:12.5 } \\
08 \\
\text { ASSET:389.1878 } \\
904\end{array}$ & $\begin{array}{l}\text { MPS:5.81611404 } \\
8 \\
\text { ROE:16.80\% } \\
\text { EPS:0.14400128 } \\
\text { DPS:0.025629 } \\
\text { DPR:0.178 } \\
\text { PE_RATIO:40.3 } \\
89 \\
\text { ASSET:131.3951 } \\
626\end{array}$ & $\begin{array}{l}\text { MPS:2.64936729 } \\
1 \\
\text { ROE:0.80\% } \\
\text { EPS:0.009610764 } \\
\text { DPS:0.012814 } \\
\text { DPR:1.333 } \\
\text { PE_RATIO:275. } \\
667 \\
\text { ASSET:31.54092 } \\
58\end{array}$ & $\begin{array}{l}\text { MPS: } 4.40333173 \\
2 \\
\text { ROE:15.00\% } \\
\text { EPS:0.384590742 } \\
\text { DPS:0.088099 } \\
\text { DPR:0.229 } \\
\text { PE_RATIO:11.4 } \\
\text { 49 } \\
\text { ASSET:30.98670 } \\
\text { 511 }\end{array}$ & $\begin{array}{l}\text { MPS:10.4396924 } \\
6 \\
\text { ROE:27.60\% } \\
\text { EPS:0.510972289 } \\
\text { DPS:0.128144 } \\
\text { DPR:0.251 } \\
\text { PE_RATIO:20.4 } \\
\text { 31 } \\
\text { ASSET:160.4837 } \\
\text { 41 }\end{array}$ \\
\hline $\begin{array}{l}2015 \\
- \\
2016\end{array}$ & $\begin{array}{l}\text { MPS:0.57354162 } \\
\text { ROE:5.80\% } \\
\text { EPS:0.036525545 } \\
\text { DPS:0.001509 } \\
\text { DPR:0.041 } \\
\text { PE_RATIO:15.7 } \\
02 \\
\text { ASSET:385.8274 } \\
847\end{array}$ & $\begin{array}{l}\text { MPS:4.34533242 } \\
8 \\
\text { ROE:14.80\% } \\
\text { EPS:0.134178553 } \\
\text { DPS:0.024149 } \\
\text { DPR:0.180 } \\
\text { PE_RATIO:32.3 } \\
85 \\
\text { ASSET:141.9666 } \\
44\end{array}$ & $\begin{array}{l}\text { MPS:3.35672779 } \\
4 \\
\text { ROE:9.20\% } \\
\text { EPS:0.1061052 } \\
\text { DPS:0.02414 } \\
\text { DPR:0.228 } \\
\text { PE_RATIO:31.6 } \\
\text { 36 } \\
\text { ASSET:31.41196 } \\
891\end{array}$ & $\begin{array}{l}\text { MPS:4.50984831 } \\
3 \\
\text { ROE:41.80\% } \\
\text { EPS:1.269338163 } \\
\text { DPS:0.083013 } \\
\text { DPR:0.065 } \\
\text { PE_RATIO:3.55 } \\
3 \\
\text { ASSET:33.78462 } \\
003\end{array}$ & $\begin{array}{l}\text { MPS:6.85985963 } \\
3 \\
\text { ROE:21.00\% } \\
\text { EPS:0.428345031 } \\
\text { DPS:0.101879 } \\
\text { DPR:0.238 } \\
\text { PE_RATIO:16.0 } \\
\text { 15 } \\
\text { ASSET:168.3948 } \\
\text { 381 }\end{array}$ \\
\hline $\begin{array}{l}2016 \\
- \\
2017\end{array}$ & $\begin{array}{l}\text { MPS:0.54270737 } \\
\text { ROE:5.60\% } \\
\text { EPS:0.038082023 } \\
\text { DPS:0.000771 } \\
\text { DPR:0.020 } \\
\text { PE_RATIO:14.2 } \\
\text { 51 } \\
\text { ASSET:397.9185 } \\
939\end{array}$ & $\begin{array}{l}\text { MPS:3.85368486 } \\
\text { ROE:12.60\% } \\
\text { EPS:0.128893 } \\
\text { DPS:0.024669 } \\
\text { DPR:0.191 } \\
\text { PE_RATIO:29.8 } \\
\text { 98 } \\
\text { ASSET:184.5050 } \\
879\end{array}$ & $\begin{array}{l}\text { MPS:6.93493678 } \\
7 \\
\text { ROE:15.35\% } \\
\text { EPS:0.195806352 } \\
\text { DPS:0.04317 } \\
\text { DPR:0.220 } \\
\text { PE_RATIO:35.4 } \\
\text { 17 } \\
\text { ASSET:38.06506 } \\
\text { 321 }\end{array}$ & $\begin{array}{l}\text { MPS:4.9128893 } \\
\text { ROE:9.98\% } \\
\text { EPS0.431082331: } \\
\text { DPS:0.084798 } \\
\text { DPR:0.197 } \\
\text { PE_RATIO:11.3 } \\
97 \\
\text { ASSET:43.86833 } \\
179\end{array}$ & $\begin{array}{l}\text { MPS:8.87372803 } \\
\text { ROE:21.90\% } \\
\text { EPS:0.514955288 } \\
\text { DPS:0.015418 } \\
\text { DPR:0.030 } \\
\text { PE_RATIO:17.2 } \\
\text { 32 } \\
\text { ASSET:183.6262 } \\
72\end{array}$ \\
\hline
\end{tabular}




\begin{tabular}{|c|c|c|c|c|c|}
\hline \multirow[t]{2}{*}{ Year } & \multicolumn{5}{|c|}{$\begin{array}{c}\text { Firm Specific Data of US and European Pharmaceutical Companies } \\
\text { Annual Financial data in millions of US Dollars }\end{array}$} \\
\hline & $\begin{array}{l}\text { Pfizer } \\
\text { (USA) }\end{array}$ & $\begin{array}{l}\text { Merck \& Co. } \\
\text { INC (USA) }\end{array}$ & $\begin{array}{l}\text { Eli Lily \& } \\
\text { Company (USA) }\end{array}$ & $\begin{array}{l}\text { Bristol-Myers } \\
\text { Squibb Company } \\
\text { (USA) }\end{array}$ & $\begin{array}{l}\text { Abbott } \\
\text { Laboratories } \\
\text { (USA) } \\
\end{array}$ \\
\hline 2008 & $\begin{array}{l}\text { MPS:17.71 } \\
\text { ROE:13.22\% } \\
\text { EPS:1.2 } \\
\text { DPS:1.28 } \\
\text { DPR:1.067 } \\
\text { PE_RATIO:14.7 } \\
\text { 58 } \\
\text { ASSET:111148 }\end{array}$ & $\begin{array}{l}\text { MPS:30.4 } \\
\text { ROE:42.30\% } \\
\text { EPS:3.65 } \\
\text { DPS:1.52 } \\
\text { DPR:0.416 } \\
\text { PE_RATIO:8.32 } \\
\text { 9 } \\
\text { ASSET:47196 }\end{array}$ & $\begin{array}{l}\text { MPS40.27: } \\
\text { ROE:-20.50\% } \\
\text { EPS:-1.89 } \\
\text { DPS:1.9 } \\
\text { DPR:-1.005 } \\
\text { PE_RATIO:- } \\
21.307 \\
\text { ASSET;29123 }\end{array}$ & $\begin{array}{l}\text { MPS:23.25 } \\
\text { ROE:54.57\% } \\
\text { EPS:2.56 } \\
\text { DPS:1.24 } \\
\text { DPR:0.484 } \\
\text { PE_RATIO:9.082 } \\
\text { ASSET:29486 }\end{array}$ & $\begin{array}{l}\text { MPS:25.54 } \\
\text { ROE:27.68\% } \\
\text { EPS:3.16 } \\
\text { DPS: } 1.44 \\
\text { DPR:0.456 } \\
\text { PE_RATIO:8.082 } \\
\text { ASSET:42419 }\end{array}$ \\
\hline 2009 & $\begin{array}{l}\text { MPS:18.19 } \\
\text { ROE:11.70\% } \\
\text { EPS:1.23 } \\
\text { DPS:0.8 } \\
\text { DPR:0.650 } \\
\text { PE_RATIO:14.7 } \\
89 \\
\text { ASSET:212949 }\end{array}$ & $\begin{array}{l}\text { MPS:36.54 } \\
\text { ROE:33.20\% } \\
\text { EPS:5.67 } \\
\text { DPS:1.52 } \\
\text { DPR:0.268 } \\
\text { PE_RATIO:6.44 } \\
4 \\
\text { ASSET:112314 }\end{array}$ & $\begin{array}{l}\text { MPS:35.71 } \\
\text { ROE:53.20\% } \\
\text { EPS:3.94 } \\
\text { DPS:1.96 } \\
\text { DPR:0.497 } \\
\text { PE_RATIO:9.06 } \\
\text { 3 } \\
\text { ASSET:27461 }\end{array}$ & $\begin{array}{l}\text { MPS:25.25 } \\
\text { ROE:78.05\% } \\
\text { EPS:5.35 } \\
\text { DPS:1.25 } \\
\text { DPR:0.234 } \\
\text { PE_RATIO:4.720 } \\
\text { ASSET:31008 }\end{array}$ & $\begin{array}{l}\text { MPS:25.83 } \\
\text { ROE:28.30\% } \\
\text { EPS:3.71 } \\
\text { DPS: } 1.6 \\
\text { DPR:0.431 } \\
\text { PE_RATIO:6.962 } \\
\text { ASSET:52582 }\end{array}$ \\
\hline 2010 & $\begin{array}{l}\text { MPS:17.15 } \\
\text { ROE:9.28\% } \\
\text { EPS:1.03 } \\
\text { DPS:0.72 } \\
\text { DPR:0.699 } \\
\text { PE_RATIO:16.6 } \\
\text { 50 } \\
\text { ASSET:195014 }\end{array}$ & $\begin{array}{l}\text { MPS:36.04 } \\
\text { ROE:1.50\% } \\
\text { EPS:0.28 } \\
\text { DPS:1.52 } \\
\text { DPR:5.429 } \\
\text { PE_RATIO:128. } \\
71 \\
\text { ASSET:105781 }\end{array}$ & $\begin{array}{l}\text { MPS:35.04 } \\
\text { ROE:46.20\% } \\
\text { EPS:4.58 } \\
\text { DPS:1.96 } \\
\text { DPR:0.428 } \\
\text { PE_RATIO:7.65 } \\
\text { 1 } \\
\text { ASSET:31001 }\end{array}$ & $\begin{array}{l}\text { MPS:26.48 } \\
\text { ROE:20.30\% } \\
\text { EPS:1.8 } \\
\text { DPS:1.29 } \\
\text { DPR:0.717 } \\
\text { PE_RATIO:14.71 } \\
1 \\
\text { ASSET:31076 }\end{array}$ & $\begin{array}{l}\text { MPS:22.92 } \\
\text { ROE:20.20\% } \\
\text { EPS:2.99 } \\
\text { DPS:1.76 } \\
\text { DPR:0.589 } \\
\text { PE_RATIO:7.666 } \\
\text { ASSET:60574 }\end{array}$ \\
\hline 2011 & $\begin{array}{l}\text { MPS:21.64 } \\
\text { ROE:11.77\% } \\
\text { EPS:1.28 } \\
\text { DPS:0.8 } \\
\text { DPR:0.625 } \\
\text { PE_RATIO:16.9 } \\
\text { 06 } \\
\text { ASSET:188002 }\end{array}$ & $\begin{array}{l}\text { MPS:37.7 } \\
\text { ROE:11.50\% } \\
\text { EPS:2.04 } \\
\text { DPS:1.52 } \\
\text { DPR:0.745 } \\
\text { PE_RATIO:18.4 } \\
\text { 80 } \\
\text { ASSET:105128 }\end{array}$ & $\begin{array}{l}\text { MPS:41.56 } \\
\text { ROE:33.50\% } \\
\text { EPS:3.9 } \\
\text { DPS:1.96 } \\
\text { DPR:0.503 } \\
\text { PE_RATIO:10.6 } \\
\text { 56 } \\
\text { ASSET:33660 }\end{array}$ & $\begin{array}{l}\text { MPS:35.24 } \\
\text { ROE:23.40\% } \\
\text { EPS:2.18 } \\
\text { DPS:1.33 } \\
\text { DPR:0.610 } \\
\text { PE_RATIO:16.16 } \\
\text { 5 } \\
\text { ASSET:32970 }\end{array}$ & $\begin{array}{l}\text { MPS:26.9 } \\
\text { ROE:20.06\% } \\
\text { EPS:3.04 } \\
\text { DPS:1.92 } \\
\text { DPR:0.632 } \\
\text { PE_RATIO:8.849 } \\
\text { ASSET60277: }\end{array}$ \\
\hline 2012 & $\begin{array}{l}\text { MPS:25.08 } \\
\text { ROE:12.24\% } \\
\text { EPS:1.96 } \\
\text { DPS:0.88 } \\
\text { DPR:0.449 } \\
\text { PE_RATIO:12.7 } \\
\text { 96 } \\
\text { ASSET:185798 }\end{array}$ & $\begin{array}{l}\text { MPS:40.94 } \\
\text { ROE:11.50\% } \\
\text { EPS:2.03 } \\
\text { DPS:1.68 } \\
\text { DPR:0.828 } \\
\text { PE_RATIO:20.1 } \\
\text { 67 } \\
\text { ASSET:106132 }\end{array}$ & $\begin{array}{l}\text { MPS:49.32 } \\
\text { ROE:28.90\% } \\
\text { EPS:3.67 } \\
\text { DPS:1.96 } \\
\text { DPR:0.534 } \\
\text { PE_RATIO:13.4 } \\
\text { 39 } \\
\text { ASSET:34399 }\end{array}$ & $\begin{array}{l}\text { MPS:32.59 } \\
\text { ROE13.30\%: } \\
\text { EPS:1.17 } \\
\text { DPS:1.37 } \\
\text { DPR:1.171 } \\
\text { PE_RATIO:27.85 } \\
5 \\
\text { ASSET:35897 }\end{array}$ & $\begin{array}{l}\text { MPS:31.34 } \\
\text { ROE:23.31\% } \\
\text { EPS:3.79 } \\
\text { DPS:2.01 } \\
\text { DPR:0.530 } \\
\text { PE_RATIO:8.269 } \\
\text { ASSET:67235 }\end{array}$ \\
\hline 2013 & $\begin{array}{l}\text { MPS:30.63 } \\
\text { ROE:27.92\% } \\
\text { EPS:3.23 } \\
\text { DPS:0.96 } \\
\text { DPR:0.297 } \\
\text { PE_RATIO:9.48 } \\
3\end{array}$ & $\begin{array}{l}\text { MPS:50.05 } \\
\text { ROE:8.60\% } \\
\text { EPS:1.49 } \\
\text { DPS:1.72 } \\
\text { DPR:1.154 } \\
\text { PE_RATIO:33.5 } \\
91\end{array}$ & $\begin{array}{l}\text { MPS:51 } \\
\text { ROE:28.90\% } \\
\text { EPS:4.33 } \\
\text { DPS:1.96 } \\
\text { DPR:0.453 } \\
\text { PE_RATIO:11.7 } \\
78\end{array}$ & $\begin{array}{l}\text { MPS:53.15 } \\
\text { ROE:17.80\% } \\
\text { EPS:1.56 } \\
\text { DPS:1.4 } \\
\text { DPR:0.897 } \\
\text { PE_RATIO:34.07 } \\
1 \\
\text { ASSET:38592 }\end{array}$ & $\begin{array}{l}\text { MPS:38.33 } \\
\text { ROE:9.92\% } \\
\text { EPS:1.65 } \\
\text { DPS:0.56 } \\
\text { DPR:0.339 } \\
\text { PE_RATIO:23.23 } \\
\text { 0 }\end{array}$ \\
\hline
\end{tabular}




\begin{tabular}{|c|c|c|c|c|c|}
\hline & ASSET:172101 & ASSET:105645 & ASSET:35249 & & ASSET:42935 \\
\hline 2014 & $\begin{array}{l}\text { MPS:31.15 } \\
\text { ROE:12.37\% } \\
\text { EPS:1.44 } \\
\text { DPS:1.04 } \\
\text { DPR:0.722 } \\
\text { PE_RATIO:21.6 } \\
\text { 32 } \\
\text { ASSET:167566 }\end{array}$ & $\begin{array}{l}\text { MPS:56.79 } \\
\text { ROE:24.20\% } \\
\text { EPS:4.12 } \\
\text { DPS:1.76 } \\
\text { DPR:0.427 } \\
\text { PE_RATIO:13.7 } \\
\text { 84 } \\
\text { ASSET:98335 }\end{array}$ & $\begin{array}{l}\text { MPS:68.99 } \\
\text { ROE:14.50\% } \\
\text { EPS:2.23 } \\
\text { DPS:1.96 } \\
\text { DPR:0.879 } \\
\text { PE_RATIO:30.9 } \\
37 \\
\text { ASSET:36308 }\end{array}$ & $\begin{array}{l}\text { MPS:59.03 } \\
\text { ROE:13.40\% } \\
\text { EPS:1.21 } \\
\text { DPS:1.44 } \\
\text { DPR:1.190 } \\
\text { PE_RATIO:48.78 } \\
5 \\
\text { ASSET:33749 }\end{array}$ & $\begin{array}{l}\text { MPS:45.02 } \\
\text { ROE:9.78\% } \\
\text { EPS:1.51 } \\
\text { DPS:0.9 } \\
\text { DPR:0.596 } \\
\text { PE_RATIO:29.81 } \\
5 \\
\text { ASSET:41207 }\end{array}$ \\
\hline 2015 & $\begin{array}{l}\text { MPS:32.28 } \\
\text { ROE:10.23\% } \\
\text { EPS:1.13 } \\
\text { DPS:1.12 } \\
\text { DPR:0.991 } \\
\text { PE_RATIO:28.5 } \\
66 \\
\text { ASSET:167381 }\end{array}$ & $\begin{array}{l}\text { MPS:52.82 } \\
\text { ROE:9.50\% } \\
\text { EPS:1.58 } \\
\text { DPS:1.8 } \\
\text { DPR:1.139 } \\
\text { PE_RATIO:33.4 } \\
\text { 30 } \\
\text { ASSET:101677 }\end{array}$ & $\begin{array}{l}\text { MPS:84.26 } \\
\text { ROE:16.10\% } \\
\text { EPS:2.27 } \\
\text { DPS:2 } \\
\text { DPR:0.881 } \\
\text { PE_RATIO:37.1 } \\
\text { 19 } \\
\text { ASSET:35569 }\end{array}$ & $\begin{array}{l}\text { MPS:68.79 } \\
\text { ROE:10.70\% } \\
\text { EPS:0.94 } \\
\text { DPS:1.48 } \\
\text { DPR:1.574 } \\
\text { PE_RATIO:73.18 } \\
1 \\
\text { ASSET:31748 }\end{array}$ & $\begin{array}{l}\text { MPS:44.91 } \\
\text { ROE:20.69\% } \\
\text { EPS:2.96 } \\
\text { DPS:0.96 } \\
\text { DPR:0.324 } \\
\text { PE_RATIO:15.17 } \\
2 \\
\text { ASSET:41247 }\end{array}$ \\
\hline 2016 & $\begin{array}{l}\text { MPS:32.48 } \\
\text { ROE:11.61\% } \\
\text { EPS:1.18 } \\
\text { DPS:1.2 } \\
\text { DPR:1.017 } \\
\text { PE_RATIO:27.5 } \\
\text { 25 } \\
\text { ASSET:171615 }\end{array}$ & $\begin{array}{l}\text { MPS:58.87 } \\
\text { ROE:9.20\% } \\
\text { EPS:1.42 } \\
\text { DPS:1.84 } \\
\text { DPR:1.296 } \\
\text { PE_RATIO:41.4 } \\
\text { 58 } \\
\text { ASSET:95377 }\end{array}$ & $\begin{array}{l}\text { MPS:73.55 } \\
\text { ROE:19.20\% } \\
\text { EPS:2.59 } \\
\text { DPS:2.04 } \\
\text { DPR:0.788 } \\
\text { PE_RATIO:28.3 } \\
\text { 98 } \\
\text { ASSET:38806 }\end{array}$ & $\begin{array}{l}\text { MPS:58.44 } \\
\text { ROE:29.30\% } \\
\text { EPS:2.67 } \\
\text { DPS:1.52 } \\
\text { DPR:0.569 } \\
\text { PE_RATIO:21.88 } \\
8 \\
\text { ASSET:33707 }\end{array}$ & $\begin{array}{l}\text { MPS38.41: } \\
\text { ROE:6.70\% } \\
\text { EPS:0.95 } \\
\text { DPS:1.04 } \\
\text { DPR:1.095 } \\
\text { PE_RATIO:40.43 } \\
2 \\
\text { ASSET:52666 }\end{array}$ \\
\hline 2017 & $\begin{array}{l}\text { MPS:36.22 } \\
\text { ROE:32.56\% } \\
\text { EPS:3.57 } \\
\text { DPS:1.28 } \\
\text { DPR:0.359 } \\
\text { PE_RATIO:10.1 } \\
46 \\
\text { ASSET:171797 }\end{array}$ & $\begin{array}{l}\text { MPS:56.27 } \\
\text { ROE:6.43\% } \\
\text { EPS:0.88 } \\
\text { DPS:1.88 } \\
\text { DPR:2.136 } \\
\text { PE_RATIO:63.9 } \\
43 \\
\text { ASSET:87872 }\end{array}$ & $\begin{array}{l}\text { MPS:84.46 } \\
\text { ROE:-1.59\% } \\
\text { EPS:-0.19 } \\
\text { DPS:2.08 } \\
\text { DPR:-10.947 } \\
\text { PE_RATIO:- } \\
\text { 444.526 } \\
\text { ASSET:44981 }\end{array}$ & $\begin{array}{l}\text { MPS:61.28 } \\
\text { ROE:7.21\% } \\
\text { EPS:0.61 } \\
\text { DPS:1.56 } \\
\text { DPR:2.557 } \\
\text { PE_RATIO:100.4 } \\
\text { 59 } \\
\text { ASSET:33551 }\end{array}$ & $\begin{array}{l}\text { MPS:57.07 } \\
\text { ROE:1.85\% } \\
\text { EPS:0.27 } \\
\text { DPS:1.06 } \\
\text { DPR:3.926 } \\
\text { PE_RATIO:211.3 } \\
\text { 70 } \\
\text { ASSET:76250 }\end{array}$ \\
\hline
\end{tabular}

\begin{tabular}{|c|c|c|c|c|c|}
\hline \multirow[t]{2}{*}{$\begin{array}{l}\text { Yea } \\
\text { r }\end{array}$} & \multicolumn{5}{|c|}{$\begin{array}{c}\text { Firm Specific Data of US and European Pharmaceutical Companies } \\
\text { Annual Financial data in millions of US Dollars }\end{array}$} \\
\hline & $\begin{array}{l}\text { Akorn } \\
\text { (USA) }\end{array}$ & $\begin{array}{l}\text { OPKO Health } \\
\text { (USA) }\end{array}$ & $\begin{array}{l}\text { Biogen INC } \\
\text { (USA) }\end{array}$ & $\begin{array}{l}\text { AMAG } \\
\text { Pharmaceutical } \\
\text { s (USA) }\end{array}$ & $\begin{array}{l}\text { BioMarin } \\
\text { Pharmaceutical } \\
\text { (USA) }\end{array}$ \\
\hline 2008 & $\begin{array}{l}\text { MPS:2.3 } \\
\text { ROE:-12.60\% } \\
\text { EPS:-0.09 } \\
\text { DPS:0 } \\
\text { DPR:0.000 } \\
\text { PE_RATIO:- } \\
\text { 25.556 } \\
\text { ASSET:82.3 }\end{array}$ & $\begin{array}{l}\text { MPS:1.62 } \\
\text { ROE:-464.70\% } \\
\text { EPS:-0.21 } \\
\text { DPS:0 } \\
\text { DPR:0.000 } \\
\text { PE_RATIO:-7.714 } \\
\text { ASSET:21.8 }\end{array}$ & $\begin{array}{l}\text { MPS:47.63 } \\
\text { ROE:13.80\% } \\
\text { EPS:2.67 } \\
\text { DPS:0 } \\
\text { DPR:0.000 } \\
\text { PE_RATIO:17. } \\
\text { 839 } \\
\text { ASSET:8479 }\end{array}$ & $\begin{array}{l}\text { MPS:35.85 } \\
\text { ROE-28.70\% } \\
\quad: \\
\text { EPS:-4.22 } \\
\text { DPS:0 } \\
\text { DPR:0.000 } \\
\text { PE_RATIO:- } \\
\text { 8.495 } \\
\text { ASSET:232 }\end{array}$ & $\begin{array}{l}\text { MPS:17.8 } \\
\text { ROE:13.27\% } \\
\text { EPS:0.31 } \\
\text { DPS:0 } \\
\text { DPR:0.000 } \\
\text { PE_RATIO:57.4 } \\
\text { 19 } \\
\text { ASSET:906.7 }\end{array}$ \\
\hline 2009 & $\begin{array}{l}\text { MPS:1.79 } \\
\text { ROE:-50.60\% }\end{array}$ & $\begin{array}{l}\text { MPS:1.83 } \\
\text { ROE:-103.70\% }\end{array}$ & $\begin{array}{l}\text { MPS:53.5 } \\
\text { ROE:16.10\% }\end{array}$ & $\begin{array}{l}\text { MPS:38.03 } \\
\text { ROE:-52.40\% }\end{array}$ & $\begin{array}{l}\text { MPS:18.81 } \\
\text { ROE:-0.16\% }\end{array}$ \\
\hline
\end{tabular}




\begin{tabular}{|c|c|c|c|c|c|}
\hline & $\begin{array}{l}\text { EPS:-0.28 } \\
\text { DPS:0 } \\
\text { DPR:0.000 } \\
\text { PE_RATIO:- } \\
6.393 \\
\text { ASSET:68.8 }\end{array}$ & $\begin{array}{l}\text { EPS:-0.15 } \\
\text { DPS:0 } \\
\text { DPR:0.00 } \\
\text { PE_RATIO:- } \\
\text { 12.200 } \\
\text { ASSET:87.4 }\end{array}$ & $\begin{array}{l}\text { EPS:3.37 } \\
\text { DPS:0 } \\
\text { DPR:0.000 } \\
\text { PE_RATIO:15. } \\
875 \\
\text { ASSET:8552 }\end{array}$ & $\begin{array}{l}\text { EPS:-5.46 } \\
\text { DPS:0 } \\
\text { DPR:0.000 } \\
\text { PE_RATIO:- } \\
\text { 6.965 } \\
\text { ASSET:184.6 }\end{array}$ & $\begin{array}{l}\text { EPS:0 } \\
\text { DPS:0 } \\
\text { DPR:\#DIV/0! } \\
\text { PE_RATIO:\#DI } \\
\text { V/0! } \\
\text { ASSET:917.2 }\end{array}$ \\
\hline 2010 & $\begin{array}{l}\text { MPS:6.07 } \\
\text { ROE:34.80\% } \\
\text { EPS:0.24 } \\
\text { DPS:0 } \\
\text { DPR:0.000 } \\
\text { PE_RATIO:25.2 } \\
\text { 92- } \\
\text { ASSET:111.1 }\end{array}$ & $\begin{array}{l}\text { MPS:3.67 } \\
\text { ROE:-35.66\% } \\
\text { EPS:-0.08 } \\
\text { DPS:0 } \\
\text { DPR:0.00 } \\
\text { PE_RATIO:- } \\
\text { 45.875 } \\
\text { ASSET:77.8 }\end{array}$ & $\begin{array}{l}\text { MPS:67.05 } \\
\text { ROE:17.30\% } \\
\text { EPS:3.98 } \\
\text { DPS:0 } \\
\text { DPR:0.000 } \\
\text { PE_RATIO:16. } \\
\text { 847 } \\
\text { ASSET:8092 }\end{array}$ & $\begin{array}{l}\text { MPS:18.1 } \\
\text { ROE:-41.80\% } \\
\text { EPS:-3.9 } \\
\text { DPS:0 } \\
\text { DPR:0.000 } \\
\text { PE_RATIO:- } \\
\text { 4.641 } \\
\text { ASSET:336.1 }\end{array}$ & $\begin{array}{l}\text { MPS:26.93 } \\
\text { ROE:39.57\% } \\
\text { EPS:2 } \\
\text { DPS:0 } \\
\text { DPR:0.000 } \\
\text { PE_RATIO:13.4 } \\
\text { 65- } \\
\text { ASSET:1262.6 }\end{array}$ \\
\hline 2011 & $\begin{array}{l}\text { MPS:11.12 } \\
\text { ROE:35.10\% } \\
\text { EPS:0.45 } \\
\text { DPS:0 } \\
\text { DPR:0.000 } \\
\text { PE_RATIO:24.7 } \\
\text { 11 } \\
\text { ASSET:307.1 }\end{array}$ & $\begin{array}{l}\text { MPS:4.9 } \\
\text { ROE:-1.11\% } \\
\text { EPS:-0.01 } \\
\text { DPS:0 } \\
\text { DPR:0.000 } \\
\text { PE_RATIO:- } \\
\text { 490.000 } \\
\text { ASSET:229.5 }\end{array}$ & $\begin{array}{l}\text { MPS:110.05 } \\
\text { ROE:20.90\% } \\
\text { EPS:5.09 } \\
\text { DPS:0 } \\
\text { DPR:0.000 } \\
\text { PE_RATIO:21. } \\
\text { 621 } \\
\text { ASSET:9050 }\end{array}$ & $\begin{array}{l}\text { MPS:18.91 } \\
\text { ROE:-36.20\% } \\
\text { EPS:-3.64 } \\
\text { DPS:0 } \\
\text { DPR:0.000 } \\
\text { PE_RATIO:- } \\
\text { 5.195 } \\
\text { ASSET:267.2 }\end{array}$ & $\begin{array}{l}\text { MPS:34.38 } \\
\text { ROE:-7.22\% } \\
\text { EPS:-0.48 } \\
\text { DPS:0 } \\
\text { DPR:0.000 } \\
\text { PE_RATIO:- } \\
\text { 71.625 } \\
\text { ASSET:1305.7 }\end{array}$ \\
\hline 2012 & $\begin{array}{l}\text { MPS:13.36 } \\
\text { ROE:19.70\% } \\
\text { EPS:0.37 } \\
\text { DPS:0 } \\
\text { DPR:0.000 } \\
\text { PE_RATIO:36.1 } \\
\text { 08 } \\
\text { ASSET:369.6 }\end{array}$ & $\begin{array}{l}\text { MPS:4.81 } \\
\text { ROE:-14.87\% } \\
\text { EPS:-0.11 } \\
\text { DPS:0 } \\
\text { DPR:0.000 } \\
\text { PE_RATIO:- } \\
43 . \overline{727} \\
\text { ASSET:289.8 }\end{array}$ & $\begin{array}{l}\text { MPS:146.37 } \\
\text { ROE:20.60\% } \\
\text { EPS:5.8 } \\
\text { DPS:0 } \\
\text { DPR:0.000 } \\
\text { PE_RATIO:25. } \\
\text { 236 } \\
\text { ASSET:10130 }\end{array}$ & $\begin{array}{l}\text { MPS:14.71 } \\
\text { ROE:-9.50\% } \\
\text { EPS:-0.78 } \\
\text { DPS:0 } \\
\text { DPR:0.000 } \\
\text { PE_RATIO:- } \\
\text { 18.859 } \\
\text { ASSET:258.1 }\end{array}$ & $\begin{array}{l}\text { MPS:49.2 } \\
\text { ROE:-12.78\% } \\
\text { EPS:-0.95 } \\
\text { DPS:N/A } \\
\text { DPR:\#VALUE! } \\
\text { PE_RATIO:- } \\
\text { 51.789 } \\
\text { ASSET:1568.3 }\end{array}$ \\
\hline 2013 & $\begin{array}{l}\text { MPS:24.62 } \\
\text { ROE:22.70\% } \\
\text { EPS:0.54 } \\
\text { DPS:0 } \\
\text { DPR:0.000 } \\
\text { PE_RATIO:45.5 } \\
\text { 93 } \\
\text { ASSET:431.8 }\end{array}$ & $\begin{array}{l}\text { MPS:8.44 } \\
\text { ROE:-21.20\% } \\
\text { EPS:-0.32 } \\
\text { DPS:0 } \\
\text { DPR:0.000 } \\
\text { PE_RATIO:- } \\
\text { 26.375 } \\
\text { ASSET:1391.5 }\end{array}$ & $\begin{array}{l}\text { MPS:279.57 } \\
\text { ROE:23.90\% } \\
\text { EPS:7.86 } \\
\text { DPS:N/A } \\
\text { DPR:\#VALUE! } \\
\text { PE_RATIO:35. } \\
\text { 569 } \\
\text { ASSET:11863 }\end{array}$ & $\begin{array}{l}\text { MPS:24.28 } \\
\text { ROE:-5.60\% } \\
\text { EPS:-0.44 } \\
\text { DPS:N/A } \\
\text { DPR:\#VALUE! } \\
\text { PE_RATIO:- } \\
\text { 55.182 } \\
\text { ASSET:265.5 }\end{array}$ & $\begin{array}{l}\text { MPS:70.35 } \\
\text { ROE:-14.97\% } \\
\text { EPS:-1.28 } \\
\text { DPS:N/A } \\
\text { DPR:\#VALUE! } \\
\text { PE_RATIO:- } \\
\text { 54.961 } \\
\text { ASSET:2244.1 }\end{array}$ \\
\hline 2014 & $\begin{array}{l}\text { MPS:36.2 } \\
\text { ROE:4.70\% } \\
\text { EPS:0.13 } \\
\text { DPS:0 } \\
\text { DPR:0.000 } \\
\text { PE_RATIO:278. } \\
\text { 462 } \\
\text { ASSET:1893.9 }\end{array}$ & $\begin{array}{l}\text { MPS:9.99 } \\
\text { ROE:-20.00\% } \\
\text { EPS:-0.41 } \\
\text { DPS:0 } \\
\text { DPR:0.000 } \\
\text { PE_RATIO:- } \\
\text { 24.366 } \\
\text { ASSET:-24.366 }\end{array}$ & $\begin{array}{l}\text { MPS:339.45 } \\
\text { ROE:30.20\% } \\
\text { EPS:12.42 } \\
\text { DPS:N/A } \\
\text { DPR:\#VALUE! } \\
\text { PE_RATIO:27. } \\
\text { 331 } \\
\text { ASSET:14315 }\end{array}$ & $\begin{array}{l}\text { MPS:42.62 } \\
\text { ROE:42.97\% } \\
\text { EPS:6.06 } \\
\text { DPS:N/A } \\
\text { DPR:\#VALUE! } \\
\text { PE_RATIO:7.0 } \\
\text { 33 } \\
\text { ASSET:1388.9 }\end{array}$ & $\begin{array}{l}\text { MPS:90.4 } \\
\text { ROE:-9.30\% } \\
\text { EPS:-0.92 } \\
\text { DPS:N/A } \\
\text { DPR:\#VALUE! } \\
\text { PE_RATIO:- } \\
\text { 98.261 } \\
\text { ASSET:2475.4 }\end{array}$ \\
\hline 2015 & $\begin{array}{l}\text { MPS:37.31 } \\
\text { ROE:30.80\% } \\
\text { EPS:1.29 } \\
\text { DPS:0 } \\
\text { DPR:0.000 } \\
\text { PE_RATIO:28.9 } \\
22\end{array}$ & $\begin{array}{l}\text { MPS:10.05 } \\
\text { ROE:-2.10\% } \\
\text { EPS:-0.06 } \\
\text { DPS:0 } \\
\text { DPR:0.000 } \\
\text { PE_RATIO:- } \\
\text { 167.500 }\end{array}$ & $\begin{array}{l}\text { MPS:306.35 } \\
\text { ROE:35.20\% } \\
\text { EPS:15.37 } \\
\text { DPS:0 } \\
\text { DPR:0.000 } \\
\text { PE_RATIO:19. } \\
\text { 932 }\end{array}$ & $\begin{array}{l}\text { MPS:30.19 } \\
\text { ROE:4.71\% } \\
\text { EPS:1.04 } \\
\text { DPS:N/A } \\
\text { DPR:\#VALUE! } \\
\text { PE_RATIO:29. } \\
\text { 029 }\end{array}$ & $\begin{array}{l}\text { MPS:104.76 } \\
\text { ROE:-8.70\% } \\
\text { EPS:-1.07 } \\
\text { DPS:N/A } \\
\text { DPR:\#VALUE! } \\
\text { PE_RATIO:- } \\
\text { 97.907 }\end{array}$ \\
\hline
\end{tabular}




\begin{tabular}{|c|c|c|c|c|c|}
\hline & ASSET:2042.5 & ASSET:2799.2 & ASSET:19505 & ASSET:2476.2 & ASSET:3729.4 \\
\hline 2016 & $\begin{array}{l}\text { MPS:21.83 } \\
\text { ROE:25.60\% } \\
\text { EPS:1.5 } \\
\text { DPS:N/A } \\
\text { DPR:\#VALUE! } \\
\text { PE_RATIO:14.5 } \\
\text { 53 } \\
\text { ASSET:1973.7 }\end{array}$ & $\begin{array}{l}\text { MPS:9.3 } \\
\text { ROE:-2.40\% } \\
\text { EPS:-0.09 } \\
\text { DPS:N/A } \\
\text { DPR:\#VALUE! } \\
\text { PE_RATIO:\#VAL } \\
\text { UE! } \\
\text { ASSET:2766.6 }\end{array}$ & $\begin{array}{l}\text { MPS:283.58 } \\
\text { ROE:34.40\% } \\
\text { EPS:16.95 } \\
\text { DPS:0 } \\
\text { DPR:0.000 } \\
\text { PE_RATIO:16. } \\
\text { 730 } \\
\text { ASSET:22877 }\end{array}$ & $\begin{array}{l}\text { MPS:34.8 } \\
\text { ROE:0.26\% } \\
\text { EPS:-0.07 } \\
\text { DPS:N/A } \\
\text { DPR:\#VALUE! } \\
\text { PE_RATIO:- } \\
\text { 497.143 } \\
\text { ASSET:2478.4 }\end{array}$ & $\begin{array}{l}\text { MPS:82.84 } \\
\text { ROE:-24.40\% } \\
\text { EPS:-3.8 } \\
\text { DPS:N/A } \\
\text { DPR:\#VALUE! } \\
\text { PE_RATIO:- } \\
\text { 21.800 } \\
\text { ASSET:-21.800 }\end{array}$ \\
\hline 2017 & $\begin{array}{l}\text { MPS:32.23 } \\
\text { ROE:-2.97\% } \\
\text { EPS:-0.2 } \\
\text { DPS:N/A } \\
\text { DPR:\#VALUE! } \\
\text { PE_RATIO:- } \\
\text { 161.150 } \\
\text { ASSET:1909.5 }\end{array}$ & $\begin{array}{l}\text { MPS:4.9 } \\
\text { ROE:-15.50\% } \\
\text { EPS:-0.55 } \\
\text { DPS:N/A } \\
\text { DPR:\#VALUE! } \\
\text { PE_RATIO:-8.909 } \\
\text { ASSET:2590 }\end{array}$ & $\begin{array}{l}\text { MPS:318.57 } \\
\text { ROE:20.51\% } \\
\text { EPS:11.94 } \\
\text { DPS:N/A } \\
\text { DPR:\#VALUE! } \\
\text { PE_RATIO:26. } \\
\text { 681 } \\
\text { ASSET:23653 }\end{array}$ & $\begin{array}{l}\text { MPS:13.25 } \\
\text { ROE:-23.10\% } \\
\text { EPS:-5.71 } \\
\text { DPS:N/A } \\
\text { DPR:\#VALUE! } \\
\text { PE_RATIO:- } \\
\text { 2.320 } \\
\text { ASSET:1900.4 }\end{array}$ & $\begin{array}{l}\text { MPS:89.17 } \\
\text { ROE:-4.19\% } \\
\text { EPS:-0.67 } \\
\text { DPS:N/A } \\
\text { DPR:\#VALUE! } \\
\text { PE_RATIO:- } \\
\text { 133.090 } \\
\text { ASSET:4633.1 }\end{array}$ \\
\hline
\end{tabular}

\begin{tabular}{|c|c|c|c|c|c|}
\hline \multirow[t]{2}{*}{ Year } & \multicolumn{5}{|c|}{$\begin{array}{c}\text { Firm Specific Data of US and European Pharmaceutical Companies } \\
\text { Annual Financial data in millions of US Dollars }\end{array}$} \\
\hline & $\begin{array}{l}\text { Sanofi SA } \\
\text { (France) }\end{array}$ & $\begin{array}{l}\text { Roche Holdings } \\
\text { (Switzerland) }\end{array}$ & $\begin{array}{l}\text { IPSEN SA } \\
\text { (France) }\end{array}$ & $\begin{array}{l}\text { Bayer AG } \\
\text { (Germany) }\end{array}$ & $\begin{array}{l}\text { NICOX SA } \\
\text { (France) }\end{array}$ \\
\hline 2008 & $\begin{array}{l}\text { MPS:32.66076 } \\
\text { ROE:8.61\% } \\
\text { EPS:2.115036 } \\
\text { DPS:1.58268 } \\
\text { DPR:0.748 } \\
\text { PE_RATIO:15.4 } \\
42 \\
\text { ASSET:51787.44 } \\
78\end{array}$ & $\begin{array}{l}\text { MPS:179.51367 } \\
\text { ROE:19.90\% } \\
\text { EPS:11.098563 } \\
\text { DPS:5.3205 } \\
\text { DPR:0.479 } \\
\text { PE_RATIO:0.47 } \\
\text { 9 } \\
\text { ASSET:80966.30 } \\
49\end{array}$ & $\begin{array}{l}\text { MPS:20.136006 } \\
\text { ROE:17.41\% } \\
\text { EPS:1.25895 } \\
\text { DPS:0.50358 } \\
\text { DPR:0.400 } \\
\text { PE_RATIO:15.994 } \\
\text { ASSET:1125.4293 } \\
\text { 6 }\end{array}$ & $\begin{array}{l}\text { MPS:39.617358 } \\
\text { ROE:10.41\% } \\
\text { EPS:1.589874 } \\
\text { DPS:0.992772 } \\
\text { DPR:0.624 } \\
\text { PE_RATIO:24.9 } \\
\text { 19 } \\
\text { ASSET:37776.41 } \\
34\end{array}$ & $\begin{array}{l}\text { MPS:24.078318 } \\
\text { ROE:-54.50\% } \\
\text { EPS:-4.841562 } \\
\text { DPS:0 } \\
\text { DPR:0.000 } \\
\text { PE_RATIO:- } \\
4.973 \\
\text { ASSET:88.9178 } \\
4\end{array}$ \\
\hline 2009 & $\begin{array}{l}\text { MPS:38.37682 } \\
\text { ROE:11.30\% } \\
\text { EPS:2.80891 } \\
\text { DPS:1.6728 } \\
\text { DPR:0.596 } \\
\text { PE_RATIO:13.6 } \\
63 \\
\text { ASSET:55934.94 } \\
7\end{array}$ & $\begin{array}{l}\text { MPS:187.0816 } \\
\text { ROE:30.00\% } \\
\text { EPS:9.374752 } \\
\text { DPS:6.2016 } \\
\text { DPR:0.662 } \\
\text { PE_RATIO:19.9 } \\
56 \\
\text { ASSET:77070.38 } \\
4\end{array}$ & $\begin{array}{l}\text { MPS:27.01572 } \\
\text { ROE:16.76\% } \\
\text { EPS: } 1.29642 \\
\text { DPS:0.52275 } \\
\text { DPR:0.403 } \\
\text { PE_RATIO:20.839 } \\
\text { ASSET:1099.0993 }\end{array}$ & $\begin{array}{l}\text { MPS:39.08776 } \\
\text { ROE:7.70\% } \\
\text { EPS:1.16399 } \\
\text { DPS:0.96186 } \\
\text { DPR:0.826 } \\
\text { PE_RATIO:33.5 } \\
81 \\
\text { ASSET:35576.27 } \\
4\end{array}$ & $\begin{array}{l}\text { MPS:0.30361 } \\
\text { ROE:-49.30\% } \\
\text { EPS:-4.18897 } \\
\text { DPS:0 } \\
\text { DPR:0.000 } \\
\text { PE_RATIO:- } \\
\text { 4.847 } \\
\text { ASSET:109.707 } \\
8\end{array}$ \\
\hline 2010 & $\begin{array}{l}\text { MPS:35.66739 } \\
\text { ROE:10.80\% } \\
\text { EPS:3.123226 } \\
\text { DPS: } 1.8635\end{array}$ & $\begin{array}{l}\text { MPS:133.10388 } \\
\text { ROE:103.00\% } \\
\text { EPS:9.451494 } \\
\text { DPS:6.15186 }\end{array}$ & $\begin{array}{l}\text { MPS:17.024936 } \\
\text { ROE:9.25\% } \\
\text { EPS:0.842302 } \\
\text { DPS:0.59632 }\end{array}$ & $\begin{array}{l}\text { MPS:41.22062 } \\
\text { ROE:6.90\% } \\
\text { EPS: } 1.15537 \\
\text { DPS: } 1.103192\end{array}$ & $\begin{array}{l}\text { MPS:8.1994 } \\
\text { ROE:-36.10\% } \\
\text { EPS:-2.258562 } \\
\text { DPS:0 }\end{array}$ \\
\hline
\end{tabular}




\begin{tabular}{|c|c|c|c|c|c|}
\hline & $\begin{array}{l}\text { DPR:0.597 } \\
\text { PE_RATIO:11.4 } \\
20 \\
\text { ASSET:63555.78 } \\
56\end{array}$ & $\begin{array}{l}\text { DPR:0.651 } \\
\text { PE_RATIO:14.0 } \\
83 \\
\text { ASSET:56876.74 } \\
2\end{array}$ & $\begin{array}{l}\text { DPR:0.708 } \\
\text { PE_RATIO:20.212 } \\
\text { ASSET:1250.9302 } \\
8\end{array}$ & $\begin{array}{l}\text { DPR:0.955 } \\
\text { PE_RATIO:35.6 } \\
77 \\
\text { ASSET:38392.57 } \\
24\end{array}$ & $\begin{array}{l}\text { DPR:0.000 } \\
\text { PE_RATIO:- } \\
\text { 3.630 } \\
\text { ASSET:84.1556 } \\
6\end{array}$ \\
\hline 2011 & $\begin{array}{l}\text { MPS:43.862075 } \\
\text { ROE:10.40\% } \\
\text { EPS:3.331199 } \\
\text { DPS:2.048185 } \\
\text { DPR:0.615 } \\
\text { PE_RATIO:13.1 } \\
67 \\
\text { ASSET:77806.29 } \\
72\end{array}$ & $\begin{array}{l}\text { MPS:156.62066 } \\
\text { ROE:86.60\% } \\
\text { EPS:10.3411 } \\
\text { DPS:6.39268 } \\
\text { DPR:0.618 } \\
\text { PE_RATIO:15.1 } \\
45 \\
\text { ASSET:57891.35 } \\
8\end{array}$ & $\begin{array}{l}\text { MPS: } 18.742825 \\
\text { ROE:0.04\% } \\
\text { EPS:0.007729 } \\
\text { DPS:0.61832 } \\
\text { DPR:80.000 } \\
\text { PE_RATIO:2425.0 } \\
\text { 00 } \\
\text { ASSET:1263.4596 } \\
3\end{array}$ & $\begin{array}{l}\text { MPS:38.18126 } \\
\text { ROE:13.00\% } \\
\text { EPS:2.272326 } \\
\text { DPS:1.252098 } \\
\text { DPR:0.551 } \\
\text { PE_RATIO:16.8 } \\
\text { 03 } \\
\text { ASSET:40767.38 } \\
34\end{array}$ & $\begin{array}{l}\text { MPS:3.9224675 } \\
\text { ROE:-18.00\% } \\
\text { EPS:-0.881106 } \\
\text { DPS:0 } \\
\text { DPR:0.000 } \\
\text { PE_RATIO:- } \\
\text { 4.452 } \\
\text { ASSET:74.0438 } \\
2\end{array}$ \\
\hline 2012 & $\begin{array}{l}\text { MPS:54.149315 } \\
\text { ROE:8.60\% } \\
\text { EPS:2.85196 } \\
\text { DPS:2.101045 } \\
\text { DPR:0.737 } \\
\text { PE_RATIO:18.9 } \\
87 \\
\text { ASSET:76160.22 } \\
65\end{array}$ & $\begin{array}{l}\text { MPS:171.16302 } \\
\text { ROE:70.80\% } \\
\text { EPS:10.183696 } \\
\text { DPS:6.73113 } \\
\text { DPR:0.661 } \\
\text { PE_RATIO:16.8 } \\
\text { 08 } \\
\text { ASSET:59351.16 } \\
64\end{array}$ & $\begin{array}{l}\text { MPS:17.271045 } \\
\text { ROE:-2.93\% } \\
\text { EPS:-0.25789 } \\
\text { DPS:0.6068 } \\
\text { DPR:-2.353 } \\
\text { PE_RATIO:- } \\
\text { 66.971 } \\
\text { ASSET:1184.7011 } \\
5\end{array}$ & $\begin{array}{l}\text { MPS:54.528565 } \\
\text { ROE:12.80\% } \\
\text { EPS:2.1693 } \\
\text { DPS:1.418395 } \\
\text { DPR:0.654 } \\
\text { PE_RATIO:25.1 } \\
\text { 36 } \\
\text { ASSET:38924.70 }\end{array}$ & $\begin{array}{l}\text { MPS:8.836525 } \\
\text { ROE:-12.90\% } \\
\text { EPS:-0.53095 } \\
\text { DPS:0 } \\
\text { DPR:0.000 } \\
\text { PE_RATIO:- } \\
\text { 16.643 } \\
\text { ASSET:63.7898 }\end{array}$ \\
\hline 2013 & $\begin{array}{l}\text { MPS:56.012256 } \\
\text { ROE:6.50\% } \\
\text { EPS:2.040903 } \\
\text { DPS:2.03364 } \\
\text { DPR:0.996 } \\
\text { PE_RATIO:27.4 } \\
\text { 45 } \\
\text { ASSET:69764.74 } \\
65\end{array}$ & $\begin{array}{l}\text { MPS:220.45814 } \\
\text { ROE:66.00\% } \\
\text { EPS:11.735787 } \\
\text { DPS:6.95058 } \\
\text { DPR:0.592 } \\
\text { PE_RATIO:18.7 } \\
\text { 85 } \\
\text { ASSET:55397.01 } \\
37\end{array}$ & $\begin{array}{l}\text { MPS:24.962931 } \\
\text { ROE:16.27\% } \\
\text { EPS1.336392: } \\
\text { DPS:0.58104 } \\
\text { DPR:0.435 } \\
\text { PE_RATIO:18.679 } \\
\text { ASSET:1136.8773 } \\
\text { 9 }\end{array}$ & $\begin{array}{l}\text { MPS:74.046285 } \\
\text { ROE:16.30\% } \\
\text { EPS:2.75994 } \\
\text { DPS:1.503441 } \\
\text { DPR:0.545 } \\
\text { PE_RATIO:26.8 } \\
\text { 29 } \\
\text { ASSET:37271.53 } \\
71\end{array}$ & $\begin{array}{l}\text { MPS:8.7192315 } \\
\text { ROE:-26.69\% } \\
\text { EPS:-0.900612 } \\
\text { DPS:0 } \\
\text { DPR:0.000 } \\
\text { PE_RATIO:- } \\
\text { 9.681 } \\
\text { ASSET:52.4388 } \\
6\end{array}$ \\
\hline 2014 & $\begin{array}{l}\text { MPS:54.89133 } \\
\text { ROE:7.76\% } \\
\text { EPS:2.42317 } \\
\text { DPS:2.067675 } \\
\text { DPR:0.853 } \\
\text { PE_RATIO:22.6 } \\
53 \\
\text { ASSET:70657.89 } \\
6\end{array}$ & $\begin{array}{l}\text { MPS:264.8583 } \\
\text { ROE:48.00\% } \\
\text { EPS:10.871308 } \\
\text { DPS:7.9136 } \\
\text { DPR:0.728 } \\
\text { PE_RATIO:24.3 } \\
63 \\
\text { ASSET:74724.16 } \\
8\end{array}$ & $\begin{array}{l}\text { MPS:31.1965 } \\
\text { ROE:15.07\% } \\
\text { EPS:1.356685 } \\
\text { DPS:0.616675 } \\
\text { DPR:0.455 } \\
\text { PE_RATIO:22.995 } \\
\text { ASSET:1242.9991 } \\
\text { 5 }\end{array}$ & $\begin{array}{l}\text { MPS:81.9815 } \\
\text { ROE:16.30\% } \\
\text { EPS:2.96004 } \\
\text { DPS:1.603355 } \\
\text { DPR:0.542 } \\
\text { PE_RATIO:27.6 } \\
\text { 96 } \\
\text { ASSET:50954.76 } \\
7\end{array}$ & $\begin{array}{l}\text { MPS:6.7580325 } \\
\text { ROE:-29.31\% } \\
\text { EPS:-1.037465 } \\
\text { DPS:0 } \\
\text { DPR:0.000 } \\
\text { PE_RATIO:- } \\
\text { 6.514 } \\
\text { ASSET:108.825 }\end{array}$ \\
\hline 2015 & $\begin{array}{l}\text { MPS:72.16266 } \\
\text { ROE:7.50\% } \\
\text { EPS:3.011368 } \\
\text { DPS:2.690033 } \\
\text { DPR:0.893 } \\
\text { PE_RATIO:23.9 } \\
\text { 63 }\end{array}$ & $\begin{array}{l}\text { MPS:275.006475 } \\
\text { ROE:43.70\% } \\
\text { EPS:10.344417 } \\
\text { DPS:8.04897 } \\
\text { DPR:0.778 } \\
\text { PE_RATIO:26.5 } \\
\text { 85}\end{array}$ & $\begin{array}{l}\text { MPS:56.0041 } \\
\text { ROE:16.59\% } \\
\text { EPS:2.120811 } \\
\text { DPS:0.780385 } \\
\text { DPR:0.368 } \\
\text { PE_RATIO:26.407 }\end{array}$ & $\begin{array}{l}\text { MPS:106.31598 } \\
\text { ROE:18.52\% } \\
\text { EPS:4.489509 } \\
\text { DPS:2.258526 } \\
\text { DPR:0.503 } \\
\text { PE_RATIO:23.6 } \\
\text { 81 }\end{array}$ & $\begin{array}{l}\text { MPS:8.3767444 } \\
\text { ROE:-28.22\% } \\
\text { EPS:-1.147625 } \\
\text { DPS:0 } \\
\text { DPR:0.000 } \\
\text { PE_RATIO:- }\end{array}$ \\
\hline
\end{tabular}




\begin{tabular}{|c|c|c|c|c|c|}
\hline & $\begin{array}{l}\text { ASSET:93940.91 } \\
01\end{array}$ & $\begin{array}{l}\text { ASSET:75285.69 } \\
31\end{array}$ & ASSET:1779.2778 & $\begin{array}{l}\text { ASSET:67863.19 } \\
77\end{array}$ & $\begin{array}{l}7.299 \\
\text { ASSET:149.925 } \\
73\end{array}$ \\
\hline 2016 & $\begin{array}{l}\text { MPS:72.8243 } \\
\text { ROE:8.14\% } \\
\text { EPS:3.46602 } \\
\text { DPS:2.80312 } \\
\text { DPR:0.809 } \\
\text { PE_RATIO:21.0 } \\
\text { 11 } \\
\text { ASSET:99131.01 } \\
3\end{array}$ & $\begin{array}{l}\text { MPS:242.2364 } \\
\text { ROE:42.70\% } \\
\text { EPS:11.440072 } \\
\text { DPS:8.34596 } \\
\text { DPR:0.730 } \\
\text { PE_RATIO:21.1 } \\
74 \\
\text { ASSET:78186.37 } \\
82\end{array}$ & $\begin{array}{l}\text { MPS:65.0589 } \\
\text { ROE:17.50\% } \\
\text { EPS:2.59478 } \\
\text { DPS:0.80495 } \\
\text { DPR:0.310 } \\
\text { PE_RATIO:25.073 } \\
\text { ASSET:2295.0545 }\end{array}$ & $\begin{array}{l}\text { MPS:92.37985 } \\
\text { ROE:16.59\% } \\
\text { EPS:5.07592 } \\
\text { DPS:2.51902 } \\
\text { DPR:0.496 } \\
\text { PE_RATIO:18.2 } \\
\text { 00 } \\
\text { ASSET:77879.38 }\end{array}$ & $\begin{array}{l}\text { MPS:8.078857 } \\
\text { ROE:-18.48\% } \\
\text { EPS:-0.7576 } \\
\text { DPS:0.000 } \\
\text { DPR:0.000 } \\
\text { PE_RATIO: - } \\
\text { 10.664 } \\
\text { ASSET:140.818 } \\
9\end{array}$ \\
\hline 2017 & $\begin{array}{l}\text { MPS:59.93727 } \\
\text { ROE:14.55\% } \\
\text { EPS:5.58914 } \\
\text { DPS:2.527626 } \\
\text { DPR:0.452 } \\
\text { PE_RATIO:10.7 } \\
24 \\
\text { ASSET:83264.00 } \\
46\end{array}$ & $\begin{array}{l}\text { MPS:240.1681 } \\
\text { ROE:34.29\% } \\
\text { EPS:9.8720 } \\
\text { DPS:8.09665 } \\
\text { DPR:0.820 } \\
\text { PE_RATIO:24.3 } \\
28 \\
\text { ASSET:74797.43 } \\
8\end{array}$ & $\begin{array}{l}\text { MPS:83.061294 } \\
\text { ROE:18.75\% } \\
\text { EPS:2.75286 } \\
\text { DPS:0.8342 } \\
\text { DPR:0.303 } \\
\text { PE_RATIO:30.173 } \\
\text { ASSET:2562.6624 }\end{array}$ & $\begin{array}{l}\text { MPS:85.38037 } \\
\text { ROE:21.85\% } \\
\text { EPS:6.915518 } \\
\text { DPS:2.302392 } \\
\text { DPR:0.333 } \\
\text { PE_RATIO:12.3 } \\
\text { 46- } \\
\text { ASSET:62637.57 } \\
54\end{array}$ & $\begin{array}{l}\text { MPS:8.458788 } \\
\text { ROE:-3.12\% } \\
\text { EPS:-0.100104 } \\
\text { DPS:0 } \\
\text { DPR:0.000 } \\
\text { PE_RATIO:- } \\
\text { 84.500 } \\
\text { ASSET:125.797 } \\
\text { 36 }\end{array}$ \\
\hline
\end{tabular}

\begin{tabular}{|c|c|c|c|c|c|}
\hline \multirow[t]{2}{*}{$\begin{array}{l}\text { Yea } \\
\text { r }\end{array}$} & \multicolumn{5}{|c|}{$\begin{array}{c}\text { Firm Specific Data of US and European Pharmaceutical Companies } \\
\text { Annual Financial data in millions of US Dollars }\end{array}$} \\
\hline & $\begin{array}{l}\text { Alliance } \\
\text { Pharmaceuticals } \\
\text { (UK) }\end{array}$ & $\begin{array}{l}\text { Virbac SA } \\
\text { (France) }\end{array}$ & $\begin{array}{l}\text { Vifor AG } \\
\text { (Switzerland) }\end{array}$ & $\begin{array}{l}\text { Novartis AG } \\
\text { (Switzerland) }\end{array}$ & $\begin{array}{l}\text { Astra Zenica PLC } \\
\text { (UK) }\end{array}$ \\
\hline 2008 & $\begin{array}{l}\text { MPS:1.8209 } \\
\text { ROE:31.25\% } \\
\text { EPS:0.0139 } \\
\text { DPS:0 } \\
\text { DPR:0.000 } \\
\text { PE_RATIO:131.0 } \\
\text { 00 } \\
\text { ASSET:33.916 }\end{array}$ & $\begin{array}{l}\text { MPS:41.682036 } \\
\text { ROE:18.63\% } \\
\text { EPS:2.956734 } \\
\text { DPS:0.86328 } \\
\text { DPR0.292: } \\
\text { PE_RATIO:14.0 } \\
\text { 97 } \\
\text { ASSET:296.8963 } \\
8\end{array}$ & $\begin{array}{l}\text { MPS:36.530553 } \\
\text { ROE:35.10\% } \\
\text { EPS:3.096531 } \\
\text { DPS:0.74487 } \\
\text { DPR:0.241 } \\
\text { PE_RATIO:11. } \\
797 \\
\text { ASSET:2236.31 } \\
256\end{array}$ & $\begin{array}{l}\text { MPS:56.07807 } \\
\text { ROE:16.47\% } \\
\text { EPS:4.0978491 } \\
\text { DPS:2.138841 } \\
\text { DPR:0.522 } \\
\text { PE_RATIO:13.6 } \\
\text { 85 } \\
\text { ASSET:88650.31 } \\
\text { 572 }\end{array}$ & $\begin{array}{l}\text { MPS:1909.86 } \\
\text { ROE:39.80\% } \\
\text { EPS:2.02245 } \\
\text { DPS:0.9869 } \\
\text { DPR:0.488 } \\
\text { PE_RATIO:944.3 } \\
\text { 30 } \\
\text { ASSET:22678.023 } \\
75\end{array}$ \\
\hline 2009 & $\begin{array}{l}\text { MPS:16.4035 } \\
\text { ROE:32.30\% } \\
\text { EPS:0.01238 } \\
\text { DPS:0 } \\
\text { DPR:0.000 } \\
\text { PE_RATIO:1325. } \\
\text { 000 } \\
\text { ASSET:35.1592 }\end{array}$ & $\begin{array}{l}\text { MPS:50.69281 } \\
\text { ROE:17.96\% } \\
\text { EPS:3.12256 } \\
\text { DPS:0.92004 } \\
\text { DPR:0.295 } \\
\text { PE_RATIO:16.2 } \\
\text { 34 } \\
\text { ASSET:302.8465 }\end{array}$ & $\begin{array}{l}\text { MPS:38.76 } \\
\text { ROE:31.20\% } \\
\text { EPS:3.338528 } \\
\text { DPS:0.7752 } \\
\text { DPR:0.232 } \\
\text { PE_RATIO:11. } \\
\text { 610 } \\
\text { ASSET:3003.95 } \\
\text { 168 }\end{array}$ & $\begin{array}{l}\text { MPS:58.34672 } \\
\text { ROE:15.60\% } \\
\text { EPS:3.948352 } \\
\text { DPS:2.149888 } \\
\text { DPR:0.545 } \\
\text { PE_RATIO:14.7 } \\
77 \\
\text { ASSET:101971.5 } \\
289\end{array}$ & $\begin{array}{l}\text { MPS:1796.0285 } \\
\text { ROE:41.10\% } \\
\text { EPS:1.98699 } \\
\text { DPS:0.87898 } \\
\text { DPR:0.442 } \\
\text { PE_RATIO:903.8 } \\
\text { 94 } \\
\text { ASSET: } \\
\text { 21043.20212 }\end{array}$ \\
\hline
\end{tabular}




\begin{tabular}{|c|c|c|c|c|c|}
\hline 2010 & $\begin{array}{l}\text { MPS: } 19.778 \\
\text { ROE:34.00\% } \\
\text { EPS:0.02552 } \\
\text { DPS:0.00638 } \\
\text { DPR:0.250 } \\
\text { PE_RATIO:775.0 } \\
\text { 00 } \\
\text { ASSET:49.3812 }\end{array}$ & $\begin{array}{l}\text { MPS:96.902 } \\
\text { ROE:23.74\% } \\
\text { EPS:5.456328 } \\
\text { DPS:1.1181 } \\
\text { DPR:0.205 } \\
\text { PE_RATIO:17.7 } \\
60 \\
\text { ASSET:397.8945 } \\
2\end{array}$ & $\begin{array}{l}\text { MPS:52.66365 } \\
\text { ROE:27.40\% } \\
\text { EPS:3.290313 } \\
\text { DPS:0.74568 } \\
\text { DPR:0.227 } \\
\text { PE_RATIO:16. } \\
\text { 006 } \\
\text { ASSET:2805.06 } \\
\text { 174 }\end{array}$ & $\begin{array}{l}\text { MPS:51.218895 } \\
\text { ROE:16.20\% } \\
\text { EPS:3.709758 } \\
\text { DPS:2.041299 } \\
\text { DPR:0.550 } \\
\text { PE_RATIO:13.8 } \\
07 \\
\text { ASSET:107139.9 } \\
549\end{array}$ & $\begin{array}{l}\text { MPS:1864.236 } \\
\text { ROE:36.70\% } \\
\text { EPS:2.27766 } \\
\text { DPS:1.03356 } \\
\text { DPR:0.454 } \\
\text { PE_RATIO:818.4 } \\
87 \\
\text { ASSET:22846.158 } \\
59\end{array}$ \\
\hline 2011 & $\begin{array}{l}\text { MPS:19.94202 } \\
\text { ROE:21.50\% } \\
\text { EPS:0.02584 } \\
\text { DPS:0.00646 } \\
\text { DPR:0.250 } \\
\text { PE_RATIO:771.7 } \\
\text { 50 } \\
\text { ASSET:53.1658 }\end{array}$ & $\begin{array}{l}\text { MPS:92.67071 } \\
\text { ROE:19.47\% } \\
\text { EPS:5.278907 } \\
\text { DPS:1.352575 } \\
\text { DPR:0.256 } \\
\text { PE_RATIO:17.5 } \\
55 \\
\text { ASSET:454.9289 } \\
4\end{array}$ & $\begin{array}{l}\text { MPS:51.658495 } \\
\text { ROE:21.80\% } \\
\text { EPS:3.252746 } \\
\text { DPS:0.84609 } \\
\text { DPR:0.260 } \\
\text { PE_RATIO:15. } \\
882 \\
\text { ASSET:2930.76 } \\
\text { 175 }\end{array}$ & $\begin{array}{l}\text { MPS:50.48337 } \\
\text { ROE:14.10\% } \\
\text { EPS:3.38436 } \\
\text { DPS:2.105824 } \\
\text { DPR:0.622 } \\
\text { PE_RATIO:14.9 } \\
17 \\
\text { ASSET:103841.5 } \\
47\end{array}$ & $\begin{array}{l}\text { MPS:1921.85 } \\
\text { ROE:42.70\% } \\
\text { EPS:3.0362 } \\
\text { DPS:1.1628 } \\
\text { DPR:0.383 } \\
\text { PE_RATIO:632.9 } \\
79 \\
\text { ASSET:22046.804 } \\
28\end{array}$ \\
\hline 2012 & $\begin{array}{l}\text { MPS:19.6215 } \\
\text { ROE:18.10\% } \\
\text { EPS:0.02472 } \\
\text { DPS:0.00618 } \\
\text { DPR:0.250 } \\
\text { PE_RATIO:793.7 } \\
\text { 50 } \\
\text { ASSET:62.1708 }\end{array}$ & $\begin{array}{l}\text { MPS:113.661225 } \\
\text { ROE:20.24\% } \\
\text { EPS:5.999735 } \\
\text { DPS:1.44115 } \\
\text { DPR:0.240 } \\
\text { PE_RATIO:18.9 } \\
44 \\
\text { ASSET:627.8104 } \\
5\end{array}$ & $\begin{array}{l}\text { MPS:48.58319 } \\
\text { ROE:21.00\% } \\
\text { EPS:3.608252 } \\
\text { DPS:1.00738 } \\
\text { DPR:0.279 } \\
\text { PE_RATIO:13. } \\
\text { 464 } \\
\text { ASSET:2886.96 } \\
792\end{array}$ & $\begin{array}{l}\text { MPS:52.61271 } \\
\text { ROE:13.70\% } \\
\text { EPS:3.2053 } \\
\text { DPS:2.10634 } \\
\text { DPR:0.657 } \\
\text { PE_RATIO:16.4 } \\
\text { 14 } \\
\text { ASSET:104157.6 } \\
979\end{array}$ & $\begin{array}{l}\text { MPS:1798.071 } \\
\text { ROE:26.60\% } \\
\text { EPS:1.8849 } \\
\text { DPS:1.7922 } \\
\text { DPR:0.951 } \\
\text { PE_RATIO:953.9 } \\
34 \\
\text { ASSET:20445.919 } \\
42\end{array}$ \\
\hline 2013 & $\begin{array}{l}\text { MPS:24.5025 } \\
\text { ROE:16.55\% } \\
\text { EPS:0.0242 } \\
\text { DPS:0.00605 } \\
\text { DPR:0.250 } \\
\text { PE_RATIO:1012. } \\
\text { 500 } \\
\text { ASSET:64.6745 }\end{array}$ & $\begin{array}{l}\text { MPS:112.79439 } \\
\text { ROE:17.13\% } \\
\text { EPS:5.214834 } \\
\text { DPS:1.37997 } \\
\text { DPR:0.265 } \\
\text { PE_RATIO:21.6 } \\
\text { 30 } \\
\text { ASSET:650.9100 } \\
6\end{array}$ & $\begin{array}{l}\text { MPS:80.02078 } \\
\text { ROE:21.10\% } \\
\text { EPS:4.072327 } \\
\text { DPS:1.24754 } \\
\text { DPR:0.306 } \\
\text { PE_RATIO:19. } \\
\text { 650 } \\
\text { ASSET:2735.14 } \\
234\end{array}$ & $\begin{array}{l}\text { MPS:63.44632 } \\
\text { ROE:12.80\% } \\
\text { EPS:2.985185 } \\
\text { DPS:2.183195 } \\
\text { DPR:0.731 } \\
\text { PE_RATIO:21.2 } \\
54 \\
\text { ASSET:100253.1 } \\
431\end{array}$ & $\begin{array}{l}\text { MPS:2162.5725 } \\
\text { ROE:10.90\% } \\
\text { EPS:0.74415 } \\
\text { DPS:1.02245 } \\
\text { DPR:1.374 } \\
\text { PE_RATIO:2906. } \\
098 \\
\text { ASSET:20460.431 } \\
48\end{array}$ \\
\hline 2014 & $\begin{array}{l}\text { MPS:23.3965 } \\
\text { ROE:12.35\% } \\
\text { EPS:0.01923 } \\
\text { DPS:0.00641 } \\
\text { DPR:0.333 } \\
\text { PE_RATIO:1216. } \\
667 \\
\text { ASSET:69.1639 }\end{array}$ & $\begin{array}{l}\text { MPS:126.45465 } \\
\text { ROE:16.06\% } \\
\text { EPS:5.47027 } \\
\text { DPS:1.37845 } \\
\text { DPR:0.252 } \\
\text { PE_RATIO:23.1 } \\
\text { 17 } \\
\text { ASSET:961.8679 }\end{array}$ & $\begin{array}{l}\text { MPS:78.34464 } \\
\text { ROE:17.68\% } \\
\text { EPS:4.342588 } \\
\text { DPS:1.4838 } \\
\text { DPR:0.342 } \\
\text { PE_RATIO:18. } \\
\text { 041 } \\
\text { ASSET:3173.65 } \\
\text { 036 }\end{array}$ & $\begin{array}{l}\text { MPS: } 91.35262 \\
\text { ROE:14.07\% } \\
\text { EPS:4.115072 } \\
\text { DPS:2.562028 } \\
\text { DPR:0.623 } \\
\text { PE_RATIO:22.2 } \\
00 \\
\text { ASSET:122693.2 } \\
655\end{array}$ & $\begin{array}{l}\text { MPS:2911.7425 } \\
\text { ROE:5.80\% } \\
\text { EPS:0.402548 } \\
\text { DPS:1.14739 } \\
\text { DPR:2.850 } \\
\text { PE_RATIO:7233. } \\
\text { 280 } \\
\text { ASSET:24075.572 }\end{array}$ \\
\hline
\end{tabular}




\begin{tabular}{|c|c|c|c|c|c|}
\hline 2015 & $\begin{array}{l}\text { MPS:29.025 } \\
\text { ROE:10.85\% } \\
\text { EPS:0.03375 } \\
\text { DPS:0.00675 } \\
\text { DPR:0.200 } \\
\text { PE_RATIO:860.0 } \\
\text { 00 } \\
\text { ASSET:190.755 }\end{array}$ & $\begin{array}{l}\text { MPS:201.79838 } \\
\text { ROE:2.16\% } \\
\text { EPS:1.028272 } \\
\text { DPS:0 } \\
\text { DPR:0.000 } \\
\text { PE_RATIO:196. } \\
250 \\
\text { ASSET:1313.433 } \\
86\end{array}$ & $\begin{array}{l}\text { MPS:156.40838 } \\
\text { ROE:16.80\% } \\
\text { EPS:4.620705 } \\
\text { DPS:1.78866 } \\
\text { DPR:0.387 } \\
\text { PE_RATIO:33. } \\
84 \\
\text { ASSET:3617.06 } \\
8\end{array}$ & $\begin{array}{l}\text { MPS:86.25316 } \\
\text { ROE:24.06\% } \\
\text { EPS:7.303695 } \\
\text { DPS:2.663116 } \\
\text { DPR:0.365 } \\
\text { PE_RATIO:11.8 } \\
\text { 10 } \\
\text { ASSET:129903.6 } \\
08\end{array}$ & $\begin{array}{l}\text { MPS:3116.1375 } \\
\text { ROE:14.80\% } \\
\text { EPS:1.0125 } \\
\text { DPS:1.27575 } \\
\text { DPR:1.260 } \\
\text { PE_RATIO:3077. } \\
\text { 667 } \\
\text { ASSET:27363.015 }\end{array}$ \\
\hline 2016 & $\begin{array}{l}\text { MPS:38.51181 } \\
\text { ROE:10.60\% } \\
\text { EPS:0.03252 } \\
\text { DPS:0.00813 } \\
\text { DPR:0.250 } \\
\text { PE_RATIO:1184. } \\
\text { 250 } \\
\text { ASSET:260.7291 }\end{array}$ & $\begin{array}{l}\text { MPS:158.3384 } \\
\text { ROE:7.58\% } \\
\text { EPS:3.89217 } \\
\text { DPS:0 } \\
\text { DPR:0.000 } \\
\text { PE_RATIO:40.6 } \\
81 \\
\text { ASSET:1342.088 } \\
4\end{array}$ & $\begin{array}{l}\text { MPS:116.94522 } \\
\text { ROE:11.68\% } \\
\text { EPS:3.725148 } \\
\text { DPS:2.0356 } \\
\text { DPR:0.546 } \\
\text { PE_RATIO:31. } \\
\text { 393 } \\
\text { ASSET:5523.70 } \\
238\end{array}$ & $\begin{array}{l}\text { MPS:75.41898 } \\
\text { ROE:8.80\% } \\
\text { EPS:2.890552 } \\
\text { DPS:2.788772 } \\
\text { DPR:0.965 } \\
\text { PE_RATIO:26.0 } \\
\text { 92 } \\
\text { ASSET:134691.6 } \\
826\end{array}$ & $\begin{array}{l}\text { MPS:3607.6875 } \\
\text { ROE:21.00\% } \\
\text { EPS:1.82925 } \\
\text { DPS:1.78047 } \\
\text { DPR:0.973 } \\
\text { PE_RATIO:1972. } \\
222 \\
\text { ASSET:41327.747 }\end{array}$ \\
\hline 2017 & $\begin{array}{l}\text { MPS:49.6688 } \\
\text { ROE:15.10\% } \\
\text { EPS:0.0444 } \\
\text { DPS:0.0074 } \\
\text { DPR:0.167 } \\
\text { PE_RATIO:1118. } \\
667 \\
\text { ASSET:249.01 }\end{array}$ & $\begin{array}{l}\text { MPS:103.0237 } \\
\text { ROE:-0.57\% } \\
\text { EPS:-0.258602 } \\
\text { DPS:0 } \\
\text { DPR:0.000 } \\
\text { PE_RATIO:- } \\
\text { 398.387 } \\
\text { ASSET:1065.523 } \\
66\end{array}$ & $\begin{array}{l}\text { MPS:121.83995 } \\
\text { ROE:44.20\% } \\
\text { EPS:17.26635 } \\
\text { DPS:1.951 } \\
\text { DPR:0.113 } \\
\text { PE_RATIO:7.0 } \\
\text { 56 } \\
\text { ASSET:4024.81 } \\
\text { 545 }\end{array}$ & $\begin{array}{l}\text { MPS:80.3812 } \\
\text { ROE:10.33\% } \\
\text { EPS:3.111845 } \\
\text { DPS:2.721645 } \\
\text { DPR:0.875 } \\
\text { PE_RATIO:25.8 } \\
\text { 31 } \\
\text { ASSET:126638.0 } \\
053\end{array}$ & $\begin{array}{l}\text { MPS:3789.54 } \\
\text { ROE: } 15.99 \% \\
\text { EPS:1.295 } \\
\text { DPS:1.4948 } \\
\text { DPR:1.154 } \\
\text { PE_RATIO:2926. } \\
286 \\
\text { ASSET:34692.650 } \\
4\end{array}$ \\
\hline
\end{tabular}

\begin{tabular}{|c|c|c|c|c|c|c|c|c|c|c|}
\hline $\begin{array}{l}\text { GDP Growth } \\
\text { Rate } \\
\text { (Year) }\end{array}$ & 2008 & 2009 & 2010 & 2011 & 2012 & 2013 & 2014 & 2015 & 2016 & 2017 \\
\hline India & $3.9 \%$ & $8.5 \%$ & $10.3 \%$ & $6.6 \%$ & $5.5 \%$ & $6.4 \%$ & $7.4 \%$ & $8.2 \%$ & $7.1 \%$ & $6.7 \%$ \\
\hline USA & $\begin{array}{l}- \\
0.3 \%\end{array}$ & $\overline{2.8 \%}$ & $2.5 \%$ & $1.6 \%$ & $2.2 \%$ & $1.7 \%$ & $2.6 \%$ & $2.9 \%$ & $1.5 \%$ & $2.3 \%$ \\
\hline $\mathbf{U} \mathbf{K}$ & $\begin{array}{l}- \\
0.5 \%\end{array}$ & $-\overline{4.2 \%}$ & $1.7 \%$ & $1.5 \%$ & $1.5 \%$ & $2.1 \%$ & $3.1 \%$ & $2.3 \%$ & $1.9 \%$ & $1.8 \%$ \\
\hline Germany & $0.8 \%$ & $\begin{array}{l}- \\
5.6 \%\end{array}$ & $3.9 \%$ & $3.7 \%$ & $0.7 \%$ & $0.6 \%$ & $1.9 \%$ & $1.5 \%$ & $1.9 \%$ & $2.5 \%$ \\
\hline France & $0.2 \%$ & $-\overline{2.9 \%}$ & $2.0 \%$ & $2.1 \%$ & $0.2 \%$ & $0.6 \%$ & $0.9 \%$ & $1.1 \%$ & $1.2 \%$ & $1.8 \%$ \\
\hline Switzerland & $2.1 \%$ & $\begin{array}{l}- \\
2.2 \%\end{array}$ & $2.9 \%$ & $1.8 \%$ & $1.00 \%$ & $1.9 \%$ & $2.5 \%$ & $1.2 \%$ & $1.4 \%$ & $1.1 \%$ \\
\hline
\end{tabular}

Key Macroeconomic Data of Selected Countries (GDP) 


\begin{tabular}{|c|c|c|c|c|c|c|c|c|c|c|}
\hline $\begin{array}{l}\text { Inflation } \\
\text { (Year) }\end{array}$ & 2008 & 2009 & 2010 & 2011 & 2012 & 2013 & 2014 & 2015 & 2016 & 2017 \\
\hline India & $9.1 \%$ & $11.0 \%$ & $9.5 \%$ & $9.5 \%$ & $10.0 \%$ & $9.4 \%$ & $5.8 \%$ & $4.9 \%$ & $4.5 \%$ & $3.6 \%$ \\
\hline USA & $3.8 \%$ & $-0.3 \%$ & $1.6 \%$ & $3.1 \%$ & $2.1 \%$ & $1.5 \%$ & $1.6 \%$ & $0.1 \%$ & $1.3 \%$ & $2.1 \%$ \\
\hline $\mathbf{U} \mathbf{K}$ & $3.6 \%$ & $2.2 \%$ & $3.3 \%$ & $4.5 \%$ & $2.8 \%$ & $2.6 \%$ & $1.5 \%$ & $0.0 \%$ & $0.7 \%$ & $2.7 \%$ \\
\hline Germany & $2.7 \%$ & $0.2 \%$ & $1.2 \%$ & $2.5 \%$ & $2.1 \%$ & $1.6 \%$ & $0.8 \%$ & $0.1 \%$ & $0.4 \%$ & $1.7 \%$ \\
\hline France & $3.2 \%$ & $0.1 \%$ & $1.7 \%$ & $2.3 \%$ & $2.2 \%$ & $1.0 \%$ & $0.6 \%$ & $0.1 \%$ & $0.3 \%$ & $1.2 \%$ \\
\hline Switzerland & $2.4 \%$ & $-0.5 \%$ & $0.7 \%$ & $0.2 \%$ & $-0.7 \%$ & $-0.2 \%$ & $0.0 \%$ & $-1.1 \%$ & $-0.4 \%$ & $0.5 \%$ \\
\hline
\end{tabular}

Key Macroeconomic Data of Selected Countries (Inflation)

\begin{tabular}{|c|c|c|c|c|c|c|c|c|c|c|}
\hline $\begin{array}{l}\text { Interest } \\
\text { Rate } \\
\text { (Year) }\end{array}$ & 2008 & 2009 & 2010 & 2011 & 2012 & 2013 & 2014 & 2015 & 2016 & 2017 \\
\hline India & $\begin{array}{l}7.33 \\
\%\end{array}$ & $5.25 \%$ & $\begin{array}{l}5.62 \\
\%\end{array}$ & $7.53 \%$ & $8.00 \%$ & $7.55 \%$ & $8.00 \%$ & $7.31 \%$ & $6.37 \%$ & $\begin{array}{l}6.00 \\
\%\end{array}$ \\
\hline USA & $\begin{array}{l}1.79 \\
\%\end{array}$ & $0.25 \%$ & $\begin{array}{l}0.25 \\
\%\end{array}$ & $0.25 \%$ & $0.25 \%$ & $0.25 \%$ & $0.25 \%$ & $\begin{array}{l}0.375 \\
\%\end{array}$ & $\begin{array}{l}0.625 \\
\%\end{array}$ & $\begin{array}{l}1.12 \\
\%\end{array}$ \\
\hline $\mathbf{U} \mathbf{K}$ & $\begin{array}{l}3.95 \\
\%\end{array}$ & $1.00 \%$ & $0.5 \%$ & $0.5 \%$ & $0.5 \%$ & $0.50 \%$ & $0.50 \%$ & $0.50 \%$ & $0.37 \%$ & $\begin{array}{l}0.50 \\
\%\end{array}$ \\
\hline Germany & $\begin{array}{l}3.16 \\
\%\end{array}$ & $1.43 \%$ & $\begin{array}{l}1.00 \\
\%\end{array}$ & $1.25 \%$ & $\begin{array}{l}0.875 \\
\%\end{array}$ & $\begin{array}{l}0.375 \\
\%\end{array}$ & $0.10 \%$ & $0.05 \%$ & $\begin{array}{l}\text { 0.025 } \\
\%\end{array}$ & $\begin{array}{l}\text { 0.00 } \\
\%\end{array}$ \\
\hline France & $\begin{array}{l}3.16 \\
\%\end{array}$ & $1.43 \%$ & $\begin{array}{l}1.00 \\
\%\end{array}$ & $1.25 \%$ & $0.87 \%$ & $0.5 \%$ & $0.15 \%$ & $0.05 \%$ & $\begin{array}{l}0.025 \\
\%\end{array}$ & $\begin{array}{l}0.00 \\
\%\end{array}$ \\
\hline $\begin{array}{l}\text { Switzerlan } \\
\text { d }\end{array}$ & $\begin{array}{l}1.56 \\
\%\end{array}$ & $\begin{array}{l}0.375 \\
\%\end{array}$ & $\begin{array}{l}0.25 \\
\%\end{array}$ & $\begin{array}{l}0.125 \\
\%\end{array}$ & $0.00 \%$ & $0.00 \%$ & $\begin{array}{l}- \\
0.125 \\
\%\end{array}$ & $\begin{array}{l}- \\
0.75 \%\end{array}$ & $\overline{-}-\overline{0.75 \%}$ & $\begin{array}{l}- \\
0.75 \\
\%\end{array}$ \\
\hline
\end{tabular}

Key Macroeconomic Data of Selected Countries (Interest Rate)

\begin{tabular}{|c|c|c|c|c|c|c|c|c|c|c|}
\hline $\begin{array}{l}\text { Corporate } \\
\text { Tax } \\
\text { (Year) }\end{array}$ & 2008 & 2009 & 2010 & 2011 & 2012 & 2013 & 2014 & 2015 & 2016 & 2017 \\
\hline India & $\begin{array}{l}33.99 \\
\% \\
\end{array}$ & $\begin{array}{l}33.99 \\
\% \\
\end{array}$ & $\begin{array}{l}33.99 \\
\% \\
\end{array}$ & $\begin{array}{l}32.44 \\
\% \\
\end{array}$ & $\begin{array}{l}32.45 \\
\% \\
\end{array}$ & $\begin{array}{l}33.99 \\
\% \\
\end{array}$ & $\begin{array}{l}33.99 \\
\% \\
\end{array}$ & $\begin{array}{l}34.61 \\
\% \\
\end{array}$ & $\begin{array}{l}34.61 \\
\% \\
\end{array}$ & $\begin{array}{l}34.61 \\
\% \\
\end{array}$ \\
\hline USA & $35 \%$ & $35 \%$ & $35 \%$ & $35 \%$ & $35 \%$ & $35 \%$ & $35 \%$ & $35 \%$ & $35 \%$ & $35 \%$ \\
\hline $\mathbf{U} \mathbf{K}$ & $30 \%$ & $28 \%$ & $28 \%$ & $26 \%$ & $24 \%$ & $23 \%$ & $21 \%$ & $20 \%$ & $20 \%$ & $19 \%$ \\
\hline Germany & $29.5 \%$ & $29.4 \%$ & $29.4 \%$ & $29.4 \%$ & $29.5 \%$ & $29.6 \%$ & $29.6 \%$ & $\begin{array}{l}29.65 \\
\% \\
\end{array}$ & $\begin{array}{l}29.72 \\
\% \\
\end{array}$ & $\begin{array}{l}29.79 \\
\%\end{array}$ \\
\hline France & $33.3 \%$ & $33.3 \%$ & $33.3 \%$ & $33.3 \%$ & $33.3 \%$ & $33.3 \%$ & $33.3 \%$ & $33.3 \%$ & $33.3 \%$ & $33.3 \%$ \\
\hline $\begin{array}{l}\text { Switzerlan } \\
\text { d }\end{array}$ & $\begin{array}{l}19.20 \\
\%\end{array}$ & $\begin{array}{l}18.96 \\
\%\end{array}$ & $\begin{array}{l}18.75 \\
\%\end{array}$ & $\begin{array}{l}18.31 \\
\%\end{array}$ & $\begin{array}{l}18.06 \\
\%\end{array}$ & $\begin{array}{l}18.01 \\
\%\end{array}$ & $\begin{array}{l}17.92 \\
\%\end{array}$ & $\begin{array}{l}17.92 \\
\%\end{array}$ & $\begin{array}{l}17.92 \\
\%\end{array}$ & $\begin{array}{l}17.77 \\
\%\end{array}$ \\
\hline
\end{tabular}

Key Macroeconomic Data of Selected Countries (Corporate Tax)

\begin{tabular}{|l|l|l|l|l|l|l|l|l|l|l|}
\hline Country & \multicolumn{10}{c|}{ Year (April-March) } \\
& \multicolumn{10}{c|}{ Indian Rupee exchange rate against one \$ USD } \\
\hline \multirow{3}{*}{ INDIA } & $\mathbf{2 0 0 7 -}$ & $\mathbf{2 0 0 8 -}$ & $\mathbf{2 0 0 9 -}$ & $\mathbf{2 0 1 0 -}$ & $\mathbf{2 0 1 1 -}$ & $\mathbf{2 0 1 2 -}$ & $\mathbf{2 0 1 3 -}$ & $\mathbf{2 0 1 4 -}$ & $\mathbf{2 0 1 5 -}$ & $\mathbf{2 0 1 6 -}$ \\
& $\mathbf{2 0 0 8}$ & $\mathbf{2 0 0 9}$ & $\mathbf{2 0 1 0}$ & $\mathbf{2 0 1 1}$ & $\mathbf{2 0 1 2}$ & $\mathbf{2 0 1 3}$ & $\mathbf{2 0 1 4}$ & $\mathbf{2 0 1 5}$ & $\mathbf{2 0 1 6}$ & $\mathbf{2 0 1 7}$ \\
\cline { 2 - 11 } & $\mathbf{3 9 . 9 4}$ & $\mathbf{4 5 . 9 0}$ & $\mathbf{4 7 . 3 5}$ & $\mathbf{4 5 . 5 3}$ & $\mathbf{4 7 . 9 0}$ & $\mathbf{5 4 . 3 8}$ & $\mathbf{6 0 . 4 5}$ & $\mathbf{6 1 . 1 3}$ & $\mathbf{6 5 . 1 7}$ & $\mathbf{6 7 . 0 3}$ \\
\hline
\end{tabular}

Key Macroeconomic Data of Selected Countries (Exchange Rate)

https://www.poundsterlinglive.com 


\begin{tabular}{|c|c|c|c|c|c|c|c|c|c|c|}
\hline \multirow[t]{2}{*}{ Country } & \multicolumn{10}{|c|}{$\begin{array}{c}\text { Year (January -December) } \\
\text { Exchange rate against one \$ USD }\end{array}$} \\
\hline & 2008 & 2009 & 2010 & 2011 & 2012 & 2013 & 2014 & 2015 & 2016 & 2017 \\
\hline USA & 1.00 & 1.00 & 1.00 & 1.00 & 1.00 & 1.00 & 1.00 & 1.00 & 1.00 & 1.00 \\
\hline $\begin{array}{l}\text { United } \\
\text { Kingdom }\end{array}$ & 0.695 & 0.619 & 0.638 & 0.646 & 0.618 & 0.605 & 0.641 & 0.675 & 0.813 & 0.74 \\
\hline Germany & 0.7194 & 0.697 & 0.7454 & 0.7729 & 0.7585 & 0.7263 & 0.7255 & 0.9181 & 0.947 & 0.8342 \\
\hline France & 0.7194 & 0.697 & 0.7454 & 0.7729 & 0.7585 & 0.7263 & 0.7255 & 0.9181 & 0.947 & 0.8342 \\
\hline Switzerland & 1.0641 & 1.0336 & 0.9321 & 0.9401 & 0.9158 & 0.8911 & 0.9892 & 0.9937 & 1.0178 & 0.9755 \\
\hline
\end{tabular}

Key Macroeconomic Data of Selected Countries (Exchange Rate)

https://www.poundsterlinglive.com 